\title{
CARACTERIZAÇÃO IMUNOLÓGICA E GENÉTICA DA DEFICIÊNCIA DO COMPONENTE C5 DO SISTEMA COMPLEMENTO HUMANO
}

\section{PRISCILIA AGUILAR RAMIREZ}

\begin{abstract}
Dissertação de Teses apresentada ao Instituto de Ciências Biomédicas da Universidade de São Paulo para a obtenção do título de Mestre em Imunologia.
\end{abstract}

São Paulo 


\section{CARACTERIZAÇÃO IMUNOLÓGICA E GENÉTICA DA DEFICIÊNCIA DO COMPONENTE C5 DO SISTEMA COMPLEMENTO HUMANO}

\section{PRISCILIA AGUILAR RAMIREZ}

Dissertação de Teses apresentada ao Instituto de Ciências Biomédicas da Universidade de São Paulo para a obtenção do título de Mestre em Imunologia. Área de concentração: Imunologia Orientadora: Professora Dra. Lourdes Isaac 
A mis padres (Alicia y Alexander) por todo su amor, cariño y apoyo incondicional em todas las etapas de mi vida.

A mis hermanitos (Alicia, Peter y Nova) por estar unidos a pesar de la distancia, hermanitos yo los quiero mucho y siempre voy a estar orgullosa de uds.

Al bebito Fabiam por devolver la ternura y la alegria a mi hogar.

A Ricardo por ser el amor de mi vida 
À família deficiente de C5 pela boa vontade e colaboração 
"Para os erros há perdão; para os fracassos, chance; para os amores impossíveis, tempo. De nada adianta cercar um coração vazio ou economizar alma. O romance cujo fim é instantâneo ou indolor não é romance. Não deixe que a saudade sufoque, que a rotina acomode, que o medo impeça de tentar. Desconfie do destino e acredite em você. Gaste mais horas realizando que sonhando, fazendo que planejando, vivendo que esperando, porque embora quem quase morre esteja vivo, quem quase vive já morreu."

Luis Fernando Veríssimo 


\section{Agradecimentos:}

À Dra. Lourdes Isaac pela sua qualidade humana, por ensinar fora e dentro do laboratório, Lou obrigada por todo o que fez por mim, como orientadora, esteve comigo e com as minhas folhas escritas e resultados até o último dia e como pessoa ajudando-me sempre que teve um problema. Obrigada pela a sua paciência.

À Dra. Beatriz Costa de Carvalho do Departamento de Alergia, Imunologia Clínica e Reumatologia, Escola Paulista de Medicina (UNIFESP), pelo acompanhamento médico da família C5 deficiênte.

Aos antigos companheiros de laboratório: Rafael, Carol, Thiago e Vitão pelos sorrisos e alegrias sem fim.

A Benício pela sua amizade e por me abrir as portas de seu lar, fazer com que a sua família fora como a minha.

Aos companheiros do laboratório: Alda, Daysseane, Lorena, Fabio, José e Edimara pela convivência agradável e bons momentos.

A Marlene, Mariane e Isabel pelos ensinos de vida que ofereceram para mim.

Aos: Drs. Antonio Condino, Denisse Tambourgi e Maria Moura, por todos os dias que se tomaram corrigindo a minha qualificação, eu segui todos os seus conselhos, obrigada por isso. Aos docentes do departamento de Imunologia: Ises de Almeida Abrahamsohn, Vera L. G. Calich, José Alexandre M. Barbuto, Sonia Jancar Negro pelos equipamentos utilizados e todo o material prestado sempre que eu precisse.

As secretarias do departamento de Imunologia: Eny, Jotelma e Valeria, pela ajuda brindada e pela eficiência de seus servicios em todo momento.

A Ricardo por nuestro amor, por aguantar mis malos dias y ajudarme en la parte final del trabajo, yo te amo.

A Marcos por ser um amigo y estar conmigo siempre que lo necesite. 
A Marcos, Julio Cesar y Andres que junto com Ricardo formarom conmigo uma família neste país.

A mis amigas del Peru: Carolina, Saby y Miriam por la fuerza desde lejos, chicas gracias por sus pensamientos positivos, por sus consejos y su cariño, las quiero mucho.

A sra. Maria, sr Joaquin e sr. Jair por nos adotar na nossa estância neste pais, vocês foram como uns pais pra nos obrigada.

A Felipe e Zilda pela amizade e os optimos almorços no bandeião.

A todos os meus amigos villarrealinos y anexos: Glenda, Miguel, Miguelito, Paola, César, Juan, Erica, Cesty, Eric y Dioguito.

A Arturo, Raul y Alexei por brindarme su sincera amistad.

A Marilu e Laércio pelas boas conversas entre experimento, pela amizade e pela ajuda prestada em todo momento. A Gaby pela disposição desinteressada e pela amistade brindada. A Renata e Simone pelas optimas traducções empre que eu necesite vocês ajudaron-me com muita boa bontade.

A Jose Maria e Mario Julio pela sua ajuda desinteresada nos primeiros dias nesta universidade.

A todos os funcionários de Instituto de Ciências Biomédicas pelo bom tratamento aos alunos.

A Renata, Jose Antonio, Ana Paula e a toda a gente da biblioteca que sempre me ajudarom com muito carinho. 


\section{RESUMO}

AGUILAR-RAMIREZ, P. Caracterização imunológica e molecular da deficiência do componente C5 do sistema complemento humano. Disertação (Mestrado em Immunologia) - Instituto de Ciências Biomédicas, Universidade de São Paulo, 2007.

A deficiência da proteína C5 do sistema complemento humano é rara. Há apenas cerca de 38 casos relatados na literatura internacional. Esta deficiência é freqüentemente associada a severas infecções recorrentes, provocadas por bactérias do gênero Neisseria. Os soros de pacientes deficientes desta proteína possuem atividade bactericida reduzida e apresentam níveis diminuídos de fatores quimiotáticos. Além disso, outras funções dependentes da adequada ativação do sistema complemento podem estar comprometidas. Observamos a ausência completa da proteína C5 no soro de três irmãos (II:4, II:5 e II:9), pertencentes a uma mesma família com história de consangüinidade. Cinco integrantes pertencentes a esta família já sofreram de episódios recorrentes de meningite e outras infecções. O objetivo principal neste trabalho é caracterizar imunológica e geneticamente esta deficiência encontrada pela primeira vez entre brasileiros. Empregando a técnica de imunodifusão dupla e imunodifusão radial obtivemos níveis expressivos das proteínas C3, C4, C6, C7, C8, C9, Fator B, Fator H e Fator I em todos os membros desta família avaliada, mas a proteína C5 não foi detectada no soro dos três irmãos. Encontramos concentrações muito baixas da proteína C5 no soro destes irmãos $(0,9 ; 1,0 ; 1,3 \mu \mathrm{g} / \mathrm{ml}$ - concentração normal em indivíduos brasileiros saudáveis: 45$190 \mu \mathrm{g} / \mathrm{ml}$ ), quando avaliados por ELISA. Os soros dos probandos II:9, II:4 e II:5 não apresentaram qualquer atividade hemolítica mediada pela via clássica ou pela via alternativa. Enretando, quando a proteína C5 purificada foi adicionada ao soro do indivíduo deficiente II:9, a atividade hemolítica mediada pela via alternativa atingiu níveis normais. O soro do pai (I:2) apresentou apenas $25 \%$ da atividade hemolítica mediada pela via clássica, enquanto a atividade hemolítica mediada pela via alternativa esteve presente em níveis normais. Deve-se ressaltar que o soro de I:2 apresentou concentrações relativamente normais da proteína C1s e 
da proteína C4. Usando a técnica de RT-PCR, a partir de RNA total extraído dos fibroblastos do indivíduo II:9, detectamos a substituição silenciosa de $\mathrm{ACC}^{498}$ por $\mathrm{ACT}^{498}$ no cDNA do gene C5, ambos os códons são responsáveis pela codificação de Thr. Os indivíduos I:1, I:2, II:4 e II:9 apresentaram uma deleção no cDNA do gene C5 localizada entre os nucleotídeos 3876 - 4029, correspondentes ao éxon 30. Estudos feitos no gene $C 5$ mostraram que a deleção do éxon 30 deve-se à substituição de $\mathrm{GAG}^{4028}$ por $\mathrm{GAA}^{4028}$ no último nucleotídeo do éxon 30 o que leva a um erro no splicing deste mesmo éxon durante o processamento do RNAm de C5. Este defeito foi responsável pela deficiência de C5 nesta família, provavelmente em função da produção de uma proteína incompleta, instável e mais rapidamente degradada após sua síntese.

Palavras Chaves: complemento, proteína C5, imunodeficiência, imunogenético, infecções por bactérias do gênero Neisseria, sistema imune 


\begin{abstract}
AGUILAR-RAMIREZ, P. Immunological and genetic characterization of the deficiency of the component $\mathrm{C} 5$ of the human complement system. Master thesis (Immunology) Instituto de Ciências Biomédicas, Universidade de São Paulo, 2007.
\end{abstract}

The deficiency of the C5 component of the complement system is rare. Only 38 described cases were described in the literature. This deficiency is frequently associated with severe and recurrent infections, especially caused by Neisseria. The deficient patients sera have less bactericidal activity and reduced production of chemotactic factors. Moreover, their sera fail to properly activate the complement system. We found complete absence of $\mathrm{C} 5$ in the serum of 3 members (II:4, II:5 e II:9) of a family with history of consanguinity. Five members of this family had suffered from recurrent episodes of meningitis, and other less severe infections. Our general objective is to characterize immunologically and genetically this deficiency, the first of its type described in the Brazilian population. Using double immunodifusion and radial immunodifusion we noted that $\mathrm{C} 3, \mathrm{C} 4, \mathrm{C} 6, \mathrm{C} 7, \mathrm{C} 8, \mathrm{C} 9$, Factor $\mathrm{B}$, Factor $\mathrm{H}$ and Factor I have expressive levels in all the individuals of this family, C5 was absent in individuals II:4, II:5 and II:9 serum. This siblings contained lowest concentrations of C5 $(0.9 ; 1.0 ; 1.3 \mu \mathrm{g} / \mathrm{ml}$ - normal concentration in health Brazilian: $45-190 \mu \mathrm{g} / \mathrm{ml})$ when evaluated by ELISA. The probands sera II:4, II:5 e II:9 were also unable to mediate the hemolytic activity by the classical and alternative pathways. When purified C5 was added to the deficient serum at approximately physiological level, hemolytic activity was restored to close to normal levels. Furthermore, the father's serum (I:2) presented only $25 \%$ of hemolytic activity mediated by the classical pathway and followed normal activity mediated by the alternative pathway. The I:2 sera presented normal levels of $\mathrm{C} 1 \mathrm{~s}$ and $\mathrm{C} 4$. Using RT-PCR of mRNA C5 obtained from the fibroblasts one of deficient (II:9), we detected a silent mutation of $\mathrm{ACC}^{498}$ to $\mathrm{ACT}^{498}$, both codons are responsible for the codification of Thr. Individuals I:1, I:2, II:4 and II:9 have a deletion in the C5 cDNA located between nucleotides 3876 - 4029, 
correspondent to exon 30. Studies shown that this deleção is due to the substitution of $\mathbf{G A G}^{\mathbf{4 0 2 8}}$ for a $\mathbf{G A A}^{\mathbf{4 0 2 8}}$ in the last codon of exon 30 that leads to exon 30 skiping during the processing of the C5 RNAm. This defect was responsible for the deficiency of C5 in this family, probably in function of the production of an incomplete, unstable protein and more quickly degraded after its synthesis.

Key words: complement, protein C5, immunodeficiency, immunogenetics, disease for bacteries of Neisseria sp.immune system 


\section{LISTA DE ABREVIATURAS:}

aa: aminoácido

Ag: antígeno

Ac: anticorpo

C1 INH: inibidor da proteína $\mathrm{Cl}$

C1q: molécula C1q do sistema complemento

C1r: molécula $\mathrm{C} 1 \mathrm{r}$ do sistema complemento

C1s: molécula $\mathrm{C} 1 \mathrm{~s}$ do sistema complemento

C2: proteína C2 do sistema complemento

C3: proteína C3 do sistema complemento

$\mathrm{C} 3\left(\mathrm{H}_{2} \mathrm{O}\right) \mathrm{Bb}$ : primeira $\mathrm{C} 3$ convertase da via alternativa

$\mathrm{C} 3 \mathrm{bBb}$ : segunda $\mathrm{C} 3$ convertase da via alternativa

$\mathrm{C} 3 \mathrm{bBb} 3 \mathrm{~b}$ : $\mathrm{C} 5$ convertase da via alternativa

C4: proteína C4 do sistema complemento

C4b2a: C3 convertase da via clássica

C4b2a3b: C5 convertase da via clássica

C4BP: C4b binding protein

C5: proteína C5 do sistema complemento

C5D: indivíduo C5 deficiênte

C6: proteína C6 do sistema complemento

C7: proteína C7 do sistema complemento

C8: proteína C8 do sistema complemento

C9: proteína C9 do sistema complemento

CCPR: complement control protein repeat

CR1: receptor do complemento do tipo 1 
CR2: receptor do complemento do tipo 2

CR3: receptor do complemento do tipo 3

CR4: receptor do complemento do tipo 4

DAF: decay accelerating factor

ESE: exonic splicing enhancers

$\mathrm{fB}$ : fator $\mathrm{B}$

fD: fator D

$\mathrm{fH}$ : fator $\mathrm{H}$

fI: fator I

FHN: fibroblasto de humano normal

GADS: síndrome de artrite e dermatite por gonococos

GAPDH: gliceraldeído fosfato desidrogenase

IFN: interferon

Ig: imunoglobulina

IL: interleucina

ICAM: molécula de adeão intercelular

LES: lúpus eritematoso sistêmico

LPS: lipopolissacarídeo de Escherichia coli

MAC: Complexo de Ataque à Membrana

MASP: serino protease associada à MBL

MBL: lectina que se liga à manose

MCP: membrane co-factor protein

PBS: salina tamponada com fosfato

VCAM: molécula de adesão das células vasculares. 


\section{LISTA DE AMINOACIDOS}

\begin{tabular}{|c|c|}
\hline Fenilalanina & Phe \\
\hline Leucina & Leu \\
\hline Isoleucina & Ile \\
\hline Metionina & Met \\
\hline Valina & Val \\
\hline Serina & Ser \\
\hline Prolina & Pro \\
\hline Treonina & Thr \\
\hline Alanina & Ala \\
\hline Tirosina & Tyr \\
\hline Histidina & His \\
\hline Glutamina & Gln \\
\hline Asparagina & Asn \\
\hline Lisina & Lys \\
\hline Ácido aspartico & Asp \\
\hline Ácido glutâmico & Glu \\
\hline Cisteina & Cys \\
\hline Triptofano & Trp \\
\hline Arginina & $\operatorname{Arg}$ \\
\hline Glicina & Gly \\
\hline
\end{tabular}

Códon de parada $\quad$ (UAA, UAG,UGA) 


\section{INDICE}

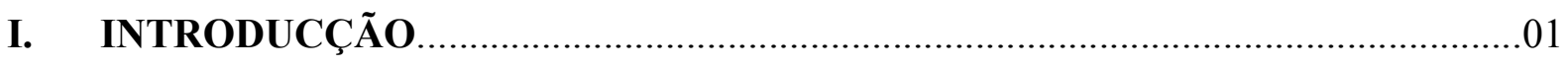

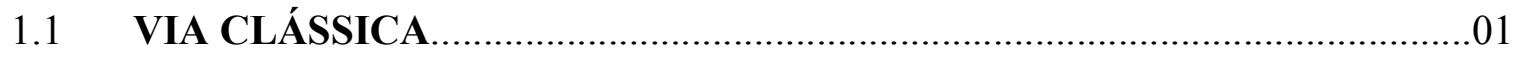

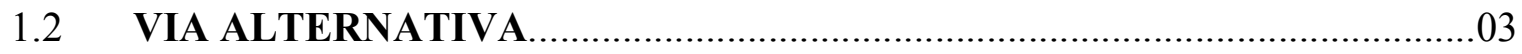

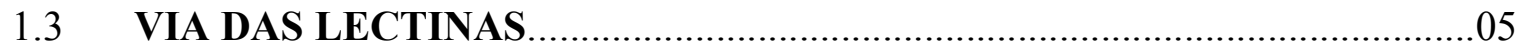

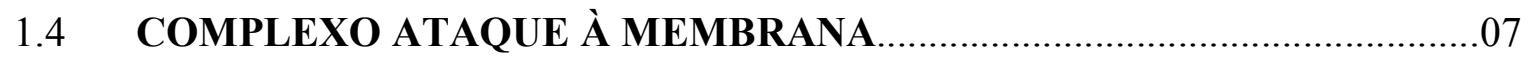

1.5 COMPONENTE C5

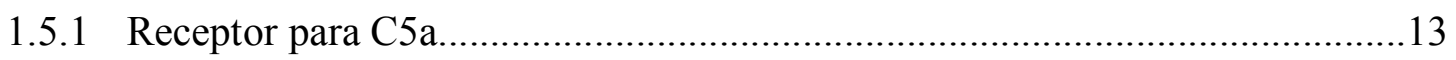

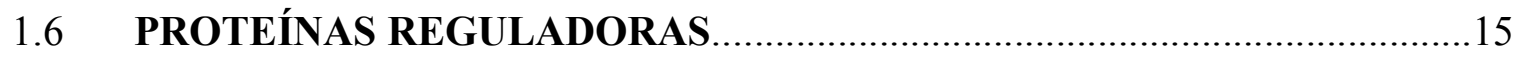

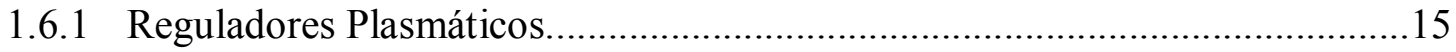

1.6.2. Reguladores associados à membrana celular................................................17

1.7 FUNÇÕES BIOLÓGICAS DERIVADAS DA ATIVAÇÃO DO SISTEMA COMPLEMENTO

1.7.1 Formação do Complexo Ataque à Membrana..................................................20

1.7.2 Produção de Anafilatoxinas.........................................................................20

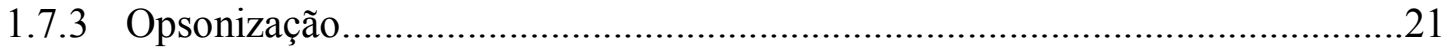

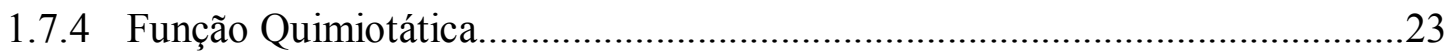

1.7.5 Solubilização e Transporte de Imunocomplexos............................................25

1.7.6 Remoção dos Imunocomplexos pelo fígado..................................................25

1.7.7 Ativação dos linfócitos B e geração de memória imunológica..........................26

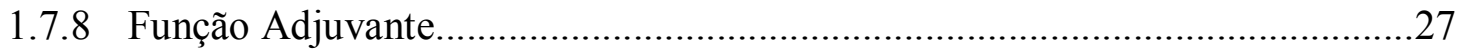

1.8 FUNÇÕES BIOLÓGICAS DERIVADAS DA PROTEÍNA C5

1.8.1 Formação do Complexo Ataque à Membrana.................................................28

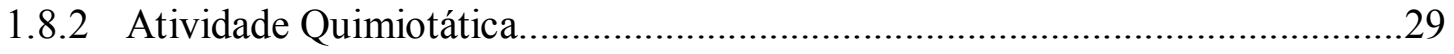


1.8.3 Aumento da Explosão Respiratória...............................................................30

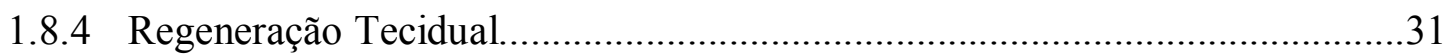

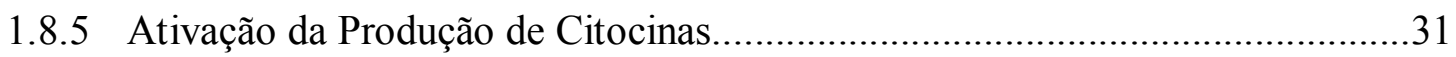

1.8.6 Regeneração de Órgãos e Tecidos.................................................................33

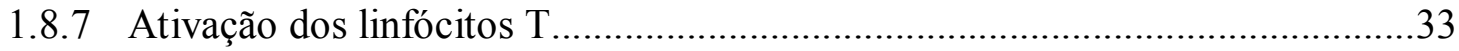

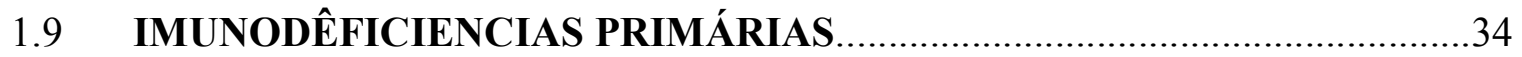

1.9.1 DEFICIÊNCIAS DAS PROTEÍNAS DE COMPLEMENTO....................39

1.9.1.1 Deficiências Das Proteínas Da Via Clássica..........................................41

1.9.1.2 Deficiências Das Proteínas Da Via Das Lectinas..................................43

1.9.1.3 Deficiências Das Proteínas Da Via Alternativa...................................44

1.9.1.4 Deficiências Das Proteínas Da Via Terminal Comum..........................47

1.9.2 DEFICIÊNCIA DA PROTEÍNA C5 ............................................................

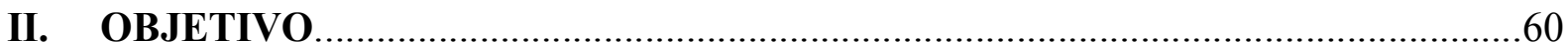

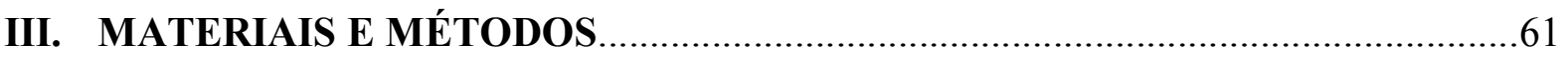

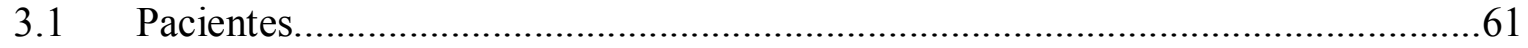

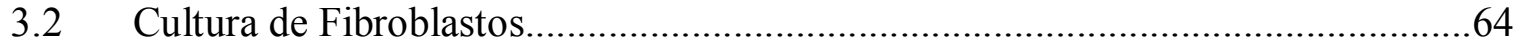

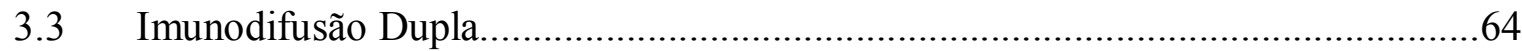

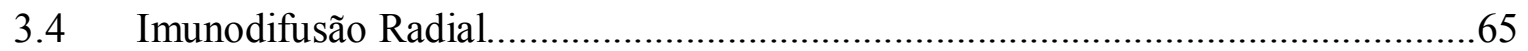

3.5 Ensaio Hemolítico mediado pela Via Clássica......................................................66

3.6 Ensaio Hemolítico mediado pela Via Alternativa..................................................66

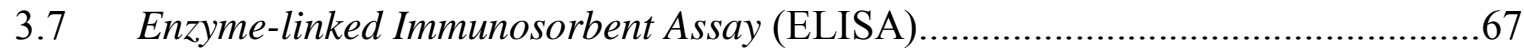

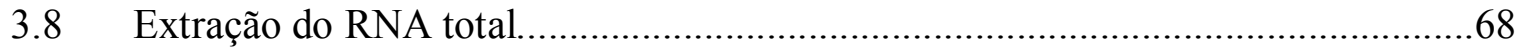

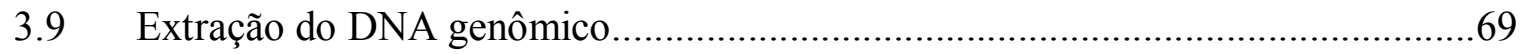

3.10 Reverse Transcriptase - Polymerase Chain Reaction RT-PCR "One Step" .69 


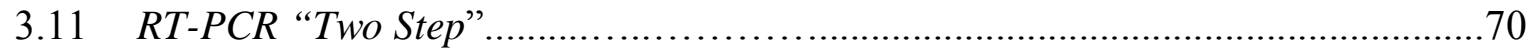

3.12 Extração de DNA a partir do gel......................................................................... 71

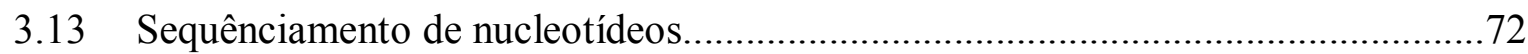

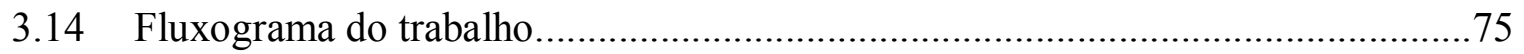

3.14.1 Determinação da Atividade Hemolítica Mediada pela Via Clássica e

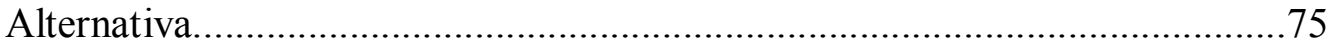

3.14.2 Determinação da Concentração sérica das proteínas de complemento nos indivíduos I:1, I:2, II:4, II:5, II:9 e famliares............................................. 75

3.14.3 Determinação das possíveis mutações presentes no material genético (DNA genômico e RNA) dos indivíduos avaliados e confirmação da mutação

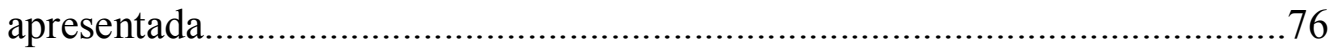

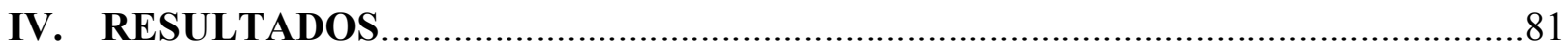

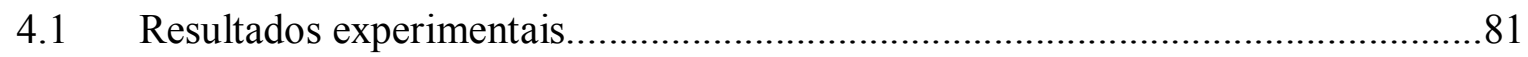

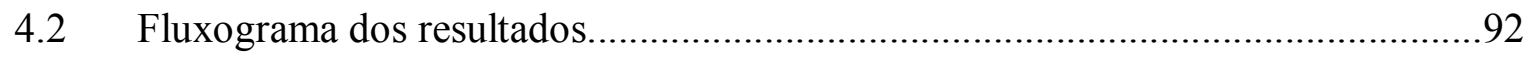

V. DISCUSSÃO

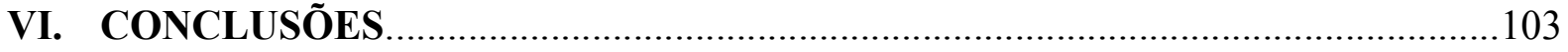

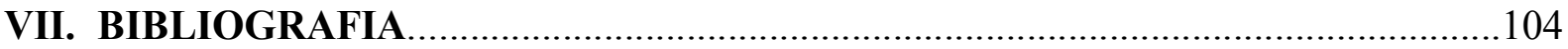




\section{INDICE DE ILUSTRAÇÕES}

Figura 1. Via Clássica do Sistema Complemento Humano.

Figura 2. Via Alternativa do Sistema Complemento Humano................................................04

Figura 3. Via Das Lectinas do Sistema Complemento Humano...........................................07

Figura 4. Estrutura de dois transcritos truncados no gene $C 5$ humano...................................11

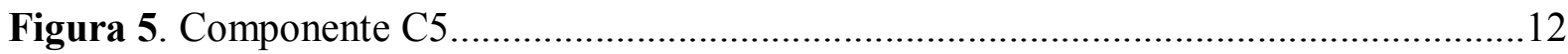

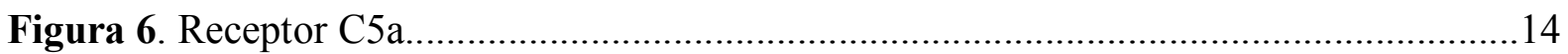

Figura 7. Proteínas Reguladoras do Sistema Complemento Humano....................................19

Figura 8. Funções dependentes do Sistema Complemento.....................................................24

Figura 9. Etapas a serem seguidas avaliação de um indivíduo com suspeita de imunodeficiência primária .35

Figura 10. Fatores que contribuem à falha da resposta imune contra meningococos em indivíduos complemento suficiêntes e indivíduos LCCD.

Figura 11. Expressão do gene $C 5$ em fibroblastos de indivíduos normais............................72

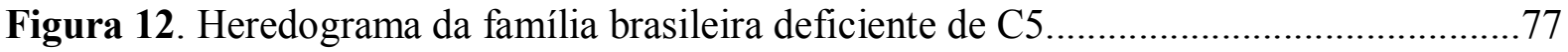

Figura 13. Imunodifusão dupla dos soros dos membros da família deficiente de C5............79

Figura 14. Amplificação do DNA genômico da região que brange o éxon1 ............................83

Figura 15. Avaliação comparativa dos produtos amplificados do cDNA C5 de vários membros desta família.

Figura 16. Sequênciamento do éxon 4 do paciente II:9 86

Figura 17. Sequênciamento dos éxons 29,30 e 31 do cDNA de $C 5$ dos indivíduos I:1, I:2, II:4 e II:9 e os respectivos cromatogramas.

Figura 18. Amplificação da região comprendida entre o éxon 29 ao éxon 31, incluindo os introns proximos do DNA genómico dos indivíduos I:1, I:2 e II:9. .88 
Figura 19. Seqüenciamento do éxon 30 do DNA genômico $C 5$ e seu respeitivo intron nos indivíduos I:1, I:2 e II:9.

Figura 20. Seqüênciamento do intron 30 e o éxon 31 do gene $C 5$ dos indivíduos I:1, I:2 e II:9.

Figura 21. Freqüência de ocorrência (\%) das bases próximas a junção éxon-íntron

Figura 22. Mecanismo geral de splicing nuclear e de grupo II 100

Figura 23. Reconhecimentos dos sítios do splicing através do éxon 101 


\section{LISTA DE TABELAS}

Tabela. 1. Proteínas do Sistema complemento $.09-10$

Tabela 2. Imunodeficiência combinada de linfócito T e/ou linfócito B..................................36

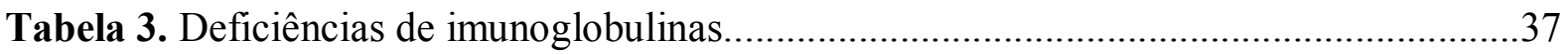

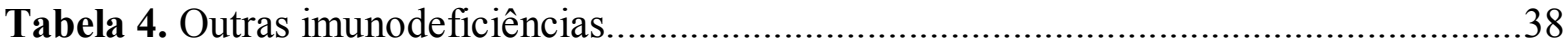

Tabela 5. Comparação da freqüência da ocorrência de infecções causadas por Neisseria sp., S. pneumoniae e H. influenzae em pacientes deficientes de complemento .39

Tabela 6. Deficiências de proteínas do sistema complemento.

Tabela 7. Comparação das doenças ocasionadas por meningococcos em indivíduos normais, LCCD e indivíduos deficientes de properdina

Tabela 8. Deficiências de C5.

Tabela 9. Atividade hemolítica mediada pela via clássica e via alternativa dos pacientes deficientes da proteína C5 (II:4, II:5 e II:9) e familiares . .78

Tabela 10. Dosagens de proteínas do complemento do soro de pacientes deficientes da proteína C5 (II:4, II:5 e II:9) e familiares .81

Tabela 11. Atividade hemolítica do soro do probando II:9, após reposição com proteína C5 humana purificada. 82 


\section{LISTA DE QUADROS}

Quadro 1. Concentração das classes de imunoglobulinas no soro do probando II:9... .62

Quadro 2. Contagem diferencial de células sangüíneas no probando II:9 .63

Quadro 3. Provas hematológicas realizadas com o probando II:9. 63

Quadro 4. Anticorpos produzidos pelo indivíduo II:9 de diferentes sorotipos contra pneumococos... .63

Quadro 5. Oligonucleotídeos utilizados na PCR, RT-PCR e sequênciamento. .74 


\section{INTRODUÇÃO}

O sistema complemento é composto por mais de 30 proteínas solúveis e de membrana, as quais participam de sua ativação e regulação, bem como de propriedades biológicas importantes que intervêm nos mecanismos de defesa inatos ou adquiridos. Este sistema é ativado seqüencialmente por pelo menos três vias: clássica, alternativa e das lectinas.

\subsection{VIA CLÁSSICA}

O complexo $\mathrm{C} 1$ é o primeiro a participar da ativação desta via. Este complexo é formado por uma molécula de C1q associada a duas moléculas de C1r e duas de C1s dependente de cálcio (LEPOW et al., 1953). C1q, por sua vez, é formado por seis arranjos moleculares, cada um deles formados por duas cadeias A; duas cadeias B e duas cadeias C estruturalmente organizadasarranjadas como um "ramalhete de tulipa".

A ativação desta via é iniciada principalmente pela ligação do C1q ao fragmento Fc das imunoglobulinas IgM ou IgG principalmente das sub-classes IgG1 e IgG3 (Figura 1). As outras classes de imunoglobulinas $\operatorname{IgA}$, IgD e IgE e a subclasse IgG4 não ativam a via clássica do complemento, enquanto a subclasse IgG2 é um ativador fraco de complemento. Para que esta ativação aconteça, dois dos seis monômeros da molécula de C1q deverão estar ligados à região $\mathrm{CH}_{3}$ da $\operatorname{IgM}$ ou $\mathrm{CH}_{2}$ da $\operatorname{IgG}$ (MÜLLER-EBERHARD \& LEPOW, 1965), as imunoglobulinas que deverão estar ligadas especificamente a antígenos. Essa ligação provoca modificações conformacionais que ativam C1r e C1s. Uma vez ativado, C1s exibe sítios catalíticos que clivam $\mathrm{C} 4$ e $\mathrm{C} 2$.

Em 1954, LEPOW et al. mostraram que agregados solúveis de antígeno-anticorpo ativavam o complexo $\mathrm{C} 1$ na presença de cálcio, além de inativar as moléculas $\mathrm{C} 2$ e C4 (hoje sabemos que na verdade são clivadas). A proteína $\mathrm{C}$ 1s ativada cliva a proteína $\mathrm{C} 4$, gerando dois fragmentos $\mathrm{C} 4 \mathrm{a}$ e $\mathrm{C} 4 \mathrm{~b}$. $\mathrm{O}$ fragmento $\mathrm{C} 4 \mathrm{~b}$ tem a propriedade de se ligar covalentemente à 
superfície de células do hospedeiro, de microorganismos ou a imunocomplexos próximos ao lugar de ativação.

C4b ligado a uma molécula aceptora irá se ligar o componente C2, o qual também será clivado pela proteína $\mathrm{C} 1 \mathrm{~s}$, gerando dois fragmentos: $\mathrm{C} 2 \mathrm{a}$ e $\mathrm{C} 2 \mathrm{~b}$. O fragmento $\mathrm{C} 2 \mathrm{a}$ permanece ligado ao fragmento $\mathrm{C} 4 \mathrm{~b}$ formando o complexo $\mathbf{C 4 b C 2 a}$ que constitui a $\mathrm{C} 3$ convertase da via clássica. WILLOUGHBY \& MAYER (1965) demonstraram que a C3 convertase formada na via clássica possui um sítio de ligação para a proteína $\mathrm{C} 3$, podendo permanecer depositada na superfície da célula alvo.

A C3 convertase é responsável pela clivagem da proteína C3. Estruturalmente, a proteína C3 é formada pela ligação de duas cadeias: a cadeia " $\alpha$ " e a cadeia " $\beta$ " unidas entre si por ponte dissulfeto. A clivagem da cadeia $\alpha$ de $\mathrm{C} 3$ ocorre graças à existência de um sítio catalítico no fragmento $\mathrm{C} 2 \mathrm{a}$ da $\mathrm{C} 3$ convertase da via clássica $(\mathbf{C 4 b C 2 a})$, gerando dois fragmentos: $\mathrm{C} 3 \mathrm{a}$ e $\mathrm{C} 3 \mathrm{~b}$. O fragmento $\mathrm{C} 3 \mathrm{~b}$ também se liga ao complexo $\mathrm{C} 4 \mathrm{bC} 2 \mathrm{a}$, gerando a C4b2a3b chamada C5 convertase da via clássica, a qual por sua vez cliva a proteína C5, gerando C5a e C5b. SHIN et al. (1971) demonstraram que o complexo formado por fragmentos de C4, C2 e C3, hoje conhecido como C5-convertase da via clássica "C4b2a3b", ao clivar a proteína C5 libera os fragmentos C5a e C5b à fase fluida. 


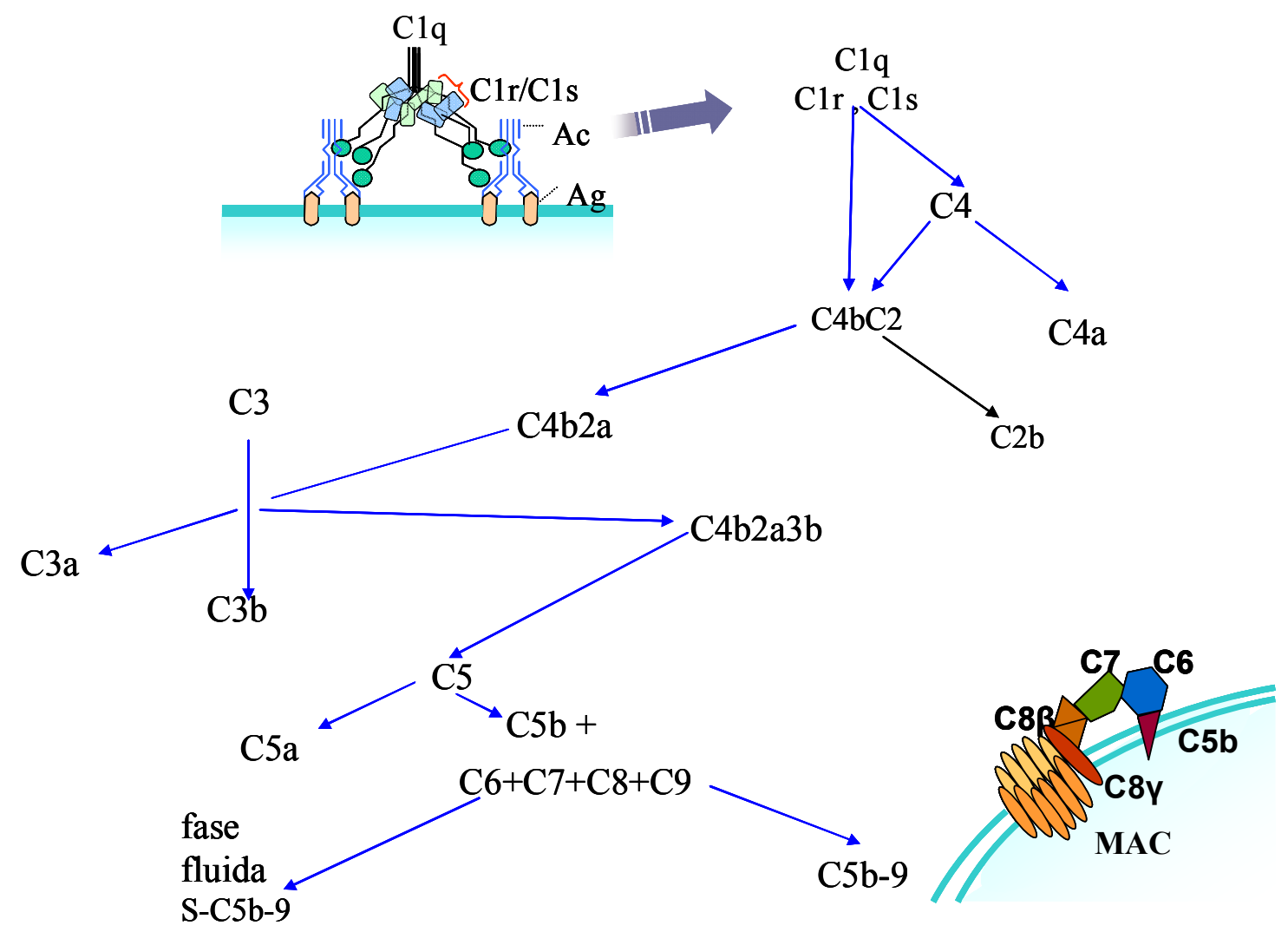

Figura 1. Via Clássica do Sistema Complemento Humano, ativada por complexos antígeno-anticorpo solúveis ou fixados na superfície da célula. C4b2a: C3 convertase; C4b2a3b: C5 convertase; S-C5b-9: complexo C5b-9 unido à proteína $\mathrm{S}$ e C5b-9: Complexo de Ataque à Membrana (MAC).

\subsection{VIA ALTERNATIVA}

A via alternativa tem um importante papel no sistema imune inato por não depender da presença de anticorpos específicos para ser ativada. É positivamente regulada pela properdina (PILLEMER et al., 1954). A ativação desta via inicia-se com a clivagem de C3 em C3a e C3b, via proteases presentes no soro ou pela hidrólise do grupo tiól-ester localizado na cadeia C3a, gerando $\mathrm{C} 3\left(\mathrm{H}_{2} \mathrm{O}\right)$ (PANGBURN \& MÜLLER-EBERHARD, 1980). Em seguida, o Fator $\mathrm{B}$, estrutural e funcionalmente semelhante a $\mathrm{C} 2$, liga-se a $\mathrm{C} 3\left(\mathrm{H}_{2} \mathrm{O}\right)$ formando $\mathrm{C} 3\left(\mathrm{H}_{2} \mathrm{O}\right)$ B. Este Fator B ligado a $\mathrm{C} 3\left(\mathrm{H}_{2} \mathrm{O}\right)$ é clivado pelo Fator D, gerando os fragmentos $\mathrm{Ba}$

e Bb. Este último participa da formação da primeira C3 convertase da via alternativa $\mathbf{C 3}\left(\mathrm{H}_{2} \mathbf{O}\right)$ Bb (Figura 2), que cliva $\mathrm{C} 3$ por meio de um sítio catalítico presente no fragmento 
$\mathrm{Bb}$, gerando os fragmentos $\mathrm{C} 3 \mathrm{a}$ e $\mathrm{C} 3 \mathrm{~b}$. Este último fragmento liga-se covalentemente a grupamentos hidroxilas encontrados em superfícies celulares ou aminas presentes em proteínas. O fragmento $\mathrm{C} 3 \mathrm{~b}$ também apresenta sítio de ligação para o Fator $\mathrm{B}$, o qual por sua vez será clivado pelo Fator D, formando-se então o complexo C3bBb (MEDICIUS et al., 1976) que atua como a segunda convertase da via alternativa clivando mais moléculas C3 em C3a e C3b. Desta forma, há uma contínua clivagem e geração dos fragmentos C3b, os quais participam diretamente da formação da C3-convertase, constituindo-se assim uma alça de amplificação que precisa ser regulada, para evitar o consumo excessivo dos componentes de complemento e a resposta inflamatória exagerada, por mecanismos que explicaremos mais adiante. $\mathrm{O}$ fragmento $\mathrm{C} 3 \mathrm{~b}$ ao se ligar à $\mathbf{C} 3 \mathbf{b B b}$ forma a $\mathrm{C} 5$ convertase $(\mathbf{C} 3 \mathbf{b B b C} \mathbf{B b})$ capaz de clivar a cadeia alfa de C5, liberando os fragmentos C5a e C5b.

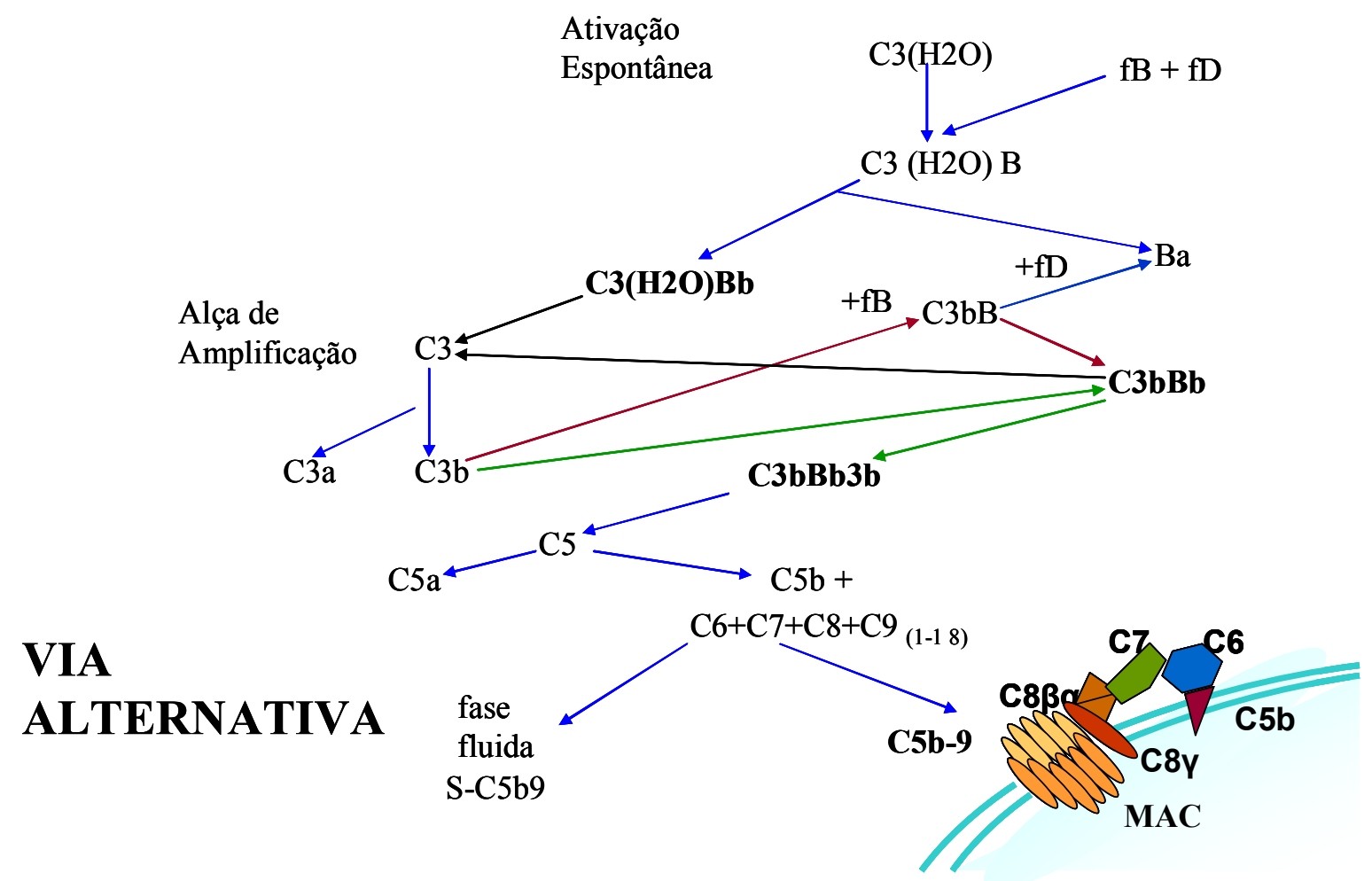

Figura 2. Via Alternativa do Sistema Complemento Humano, iniciada pela hidrólise espontânea de $\mathrm{C} 3$ gerando $\mathrm{C} 3\left(\mathrm{H}_{2} 0\right)$. $\mathrm{C} 3\left(\mathrm{H}_{2} 0\right) \mathrm{Bb}$ : primeira $\mathrm{C} 3$ convertase; $\mathrm{C} 3 \mathrm{bBb}$ : segunda $\mathrm{C} 3$ convertase; $\mathrm{C} 3 \mathrm{bBb} 3 \mathrm{~b}$ : $\mathrm{C} 5$ convertase; $\mathrm{S}-\mathrm{C} 5 \mathrm{~b}-9$ : complexo $\mathrm{C} 5 \mathrm{~b}-9$ unido à proteína $\mathrm{S}, \mathrm{MAC}$ : Complexo de Ataque à Membrana. 


\subsection{VIA DAS LECTINAS}

A proteína ligante de manose (MBL - mannose-binding lectin) é uma lectina tipo $\mathrm{C}$, parecida estruturalmente à proteína $\mathrm{C} 1 \mathrm{q}$, capaz de se ligar na presença de íons cálcio a grupos de manose ou $\mathrm{N}$-acetilglucosamina (IHARA et al., 1982), presentes nas paredes celulares de leveduras, bactérias gram-negativas e outras células. Diferentemente de C1q, a MBL pode ser isolada em forma de dímeros, trímeros, tetrâmeros, pentâmeros e hexâmeros.

MATSUSHITA \& FUJITA (1992) encontraram uma serino-protease distinta da proteína $\mathrm{C} 1 \mathrm{~s}$ que se associava a MBL, à qual denominaram MASP (do inglês $M B P$ associated serine protease), que induz a ligação e a clivagem das proteínas C4 e C2 (Figura 3). Esta serino-protease associada à MBL chamada MASP (na época apenas uma MASP havia sido descrita) em condições não redutoras é formada por uma banda de $83 \mathrm{kDa}$, semelhante à proteína $\mathrm{C} 1 \mathrm{~s}$. Em condições redutoras, duas cadeias, uma pesada (66 kDa) e uma leve $(31 \mathrm{kDa})$ podem ser visualizadas após electroforese. Estes autores também encontraram seqüências homólogas da região amino-terminal da cadeia leve da MASP com as proteínas $\mathrm{C} 1 \mathrm{~s}$ e $\mathrm{C} 1 \mathrm{r}$.

THIEL et al. (1997) descreveram uma nova serino-protease associada à membrana à qual denominaram MASP-2, que sob condições redutoras mostra-se formada por duas cadeias: uma pesada de $52 \mathrm{kDa}$ e uma leve de $32 \mathrm{kDa}$, unidas entre si por ponte dissulfeto. Ao compararem as regiões amino-terminais das proteínas C1s, C1r, MASP-1 e MASP-2, estes autores observaram que estas quatro proteínas possuem em comum três aminoácidos essenciais (His ${ }^{468}, \mathrm{Asp}^{517}$ e $\mathrm{Ser}^{618}$ ) para a formação de seu centro ativo. Estes autores também observaram que a ativação da MASP-2, também se dá pela clivagem entre os resíduos Arg e Ile, igualmente ao observado nas proteínas $\mathrm{C} 1 \mathrm{~s}$, C1r e MASP-1, localizados entre o domínio CCP e o domínio serino-protease. Por se observar uma alta similaridade entre MASP-2 e C1s (47\%) e entre MASP-1 e C1r (52\%) foi inferido e posteriormente constatado que MASP-2 
poderia também ativar C4. MATSUSHITA et al. (2000), observaram que a forma ativa de MASP-2 tem a capacidade de consumir $\mathrm{C} 4$, ativar $\mathrm{C} 2$ e clivar $\mathrm{C} 3$ em suas cadeias $\alpha$ e $\beta$. A forma ativa de MASP-1 cliva a cadeia $\alpha$ de C3 gerando C3a e C3b.

Uma forma truncada da MASP-2, conhecida como uma pequena proteína não enzimática associada a MBL (sMAP) ou conhecida como um peptídeo de $19 \mathrm{kDa}$ ligado a MBL (MAP-19) foi descoberta por TAKAHASHI et al. (1999). DAHL et al. (2001) descreveram um novo tipo de MASP, hoje conhecida como MASP-3, que tem a capacidade de ligar-se a MBL, mas ao se misturar rMASP-3 com plasma contendo complexos formados por MBL-manose e C4, eles observaram uma forte inibição do consumo e ativação do $\mathrm{C} 4$. Esta inibição também ocorreu quando MASP-3 competiu contra MASP-2 pela ligação com MBL o que também inibe a ativação da via das lectinas.

ZUNDEL et al. (2004) constataram que MASP-3 não reage diretamente com o inibidor de $\mathrm{C} 1(\mathrm{C} 1-\mathrm{INH})$, e nem se liga às proteínas $\mathrm{C} 2, \mathrm{C} 4$ e $\mathrm{C} 3$, somente cliva o substrato N-carboxibenziloxiglicina-L-arginina tiobenzil ester. CORTESIO \& JIANG (2006) demonstraram que MASP-3 e MASP-1 derivam do mesmo gene, contendo as duas a mesma cadeia "A" e uma cadeia "B" que só difere pela localização do centro catalítico. 


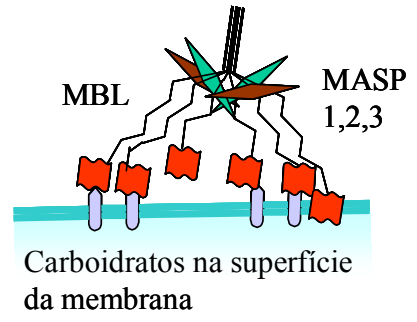

VIA DAS

LECTINAS
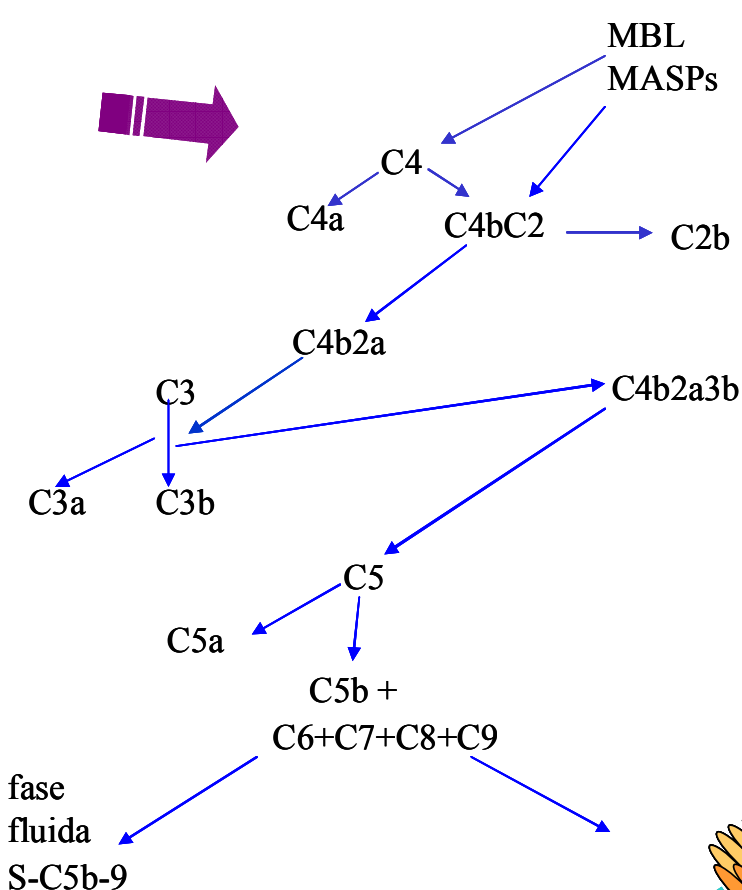

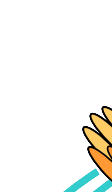

MAC

Figura 3. Via Das Lectinas do Sistema Complemento Humano, ativada pela Lectina Ligante de Manose (MBL) que in vivo se liga a manose e a resíduos de $\mathrm{N}$-acetilglicosamina presentes em abundância nas paredes celulares de bactérias. MASP: serino protease associada à MBL. S-C5b-9: complexo C5b-9 unido à proteína S. Complexo de Ataque à Membrana (MAC). MASP-3 liga-se à MBL, mas não ativa complemento.

\subsection{COMPLEXO DE ATAQUE À MEMBRANA}

Estas três vias convergem para uma via terminal comum que resulta na formação e deposição do complexo de ataque à membrana (MAC), o qual se deposita sobre as superfícies de microorganismos patogênicos, membranas de células infectadas por alguns tipos de vírus e células de certas linhagens de células tumorais.

A formação deste complexo citolítico é iniciada pela clivagem da proteína C5 em C5a e C5b. Ao fragmento gerado C5b se liga a proteína C6 (120 kDa) do sistema complemento. Este complexo (C5b6) permite a ligação da proteína C7 (110 kDa). O componente C7 é uma proteína de cadeia única, estruturalmente semelhante à proteína C6, e com sua ligação a C5b6, 
forma-se o complexo C5b67. Este complexo liga-se a uma superfície hidrofóbica, que pode ser a membrana da célula alvo.

A próxima proteína que fará parte do MAC é C8 estruturalmente formada por três cadeias $\alpha, \beta$ e $\gamma$. A cadeia $\alpha$ de $64 \mathrm{kDa}$ e a cadeia $\gamma$ de $22 \mathrm{kDa}$ estão unidas entre si por ponte dissulfeto e a cadeia $\beta$ de $64 \mathrm{kDa}$ une-se à subunidade $\mathrm{C} 5 \mathrm{~b}$ do complexo $\mathrm{C} 5 \mathrm{~b} 67$. O complexo resultante $\mathrm{C} 5 \mathrm{~b} 678$ resulta na formação de pequenos poros, que podem causar lise da célula alvo mesmo antes da inserção de vários monômeros de C9. A inserção do primeiro monômero de C9 ao complexo C5b678 é feita na cadeia $\alpha$ da proteína C8 e as ligações seguintes desta proteína (até 18 monômeros de C9) ocorrem através de pontes dissulfetos entre os monômeros. A união destes monômeros permite a formação de cilindros ou poros intracitoplasmáticos, cujo diâmetro e estabilização dependerão do número de monômeros de C9 ligados ao complexo C5b678 (WARE \& KOLB, 1981). A formação deste complexo de

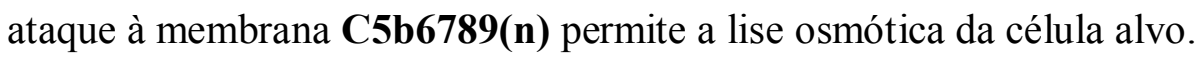

SHINKAY et al. (1988) mostraram que a molécula de C9 é homóloga à perforina. O seqüenciamento dos cDNAs dos genes da perforina e do C9 em células de camundongo, revelou que a região compreendida entre os resíduos 170-390 da perforina é homóloga à região compreendida entre o resíduos 328-560 do gene $C 9$, sendo ambas as moléculas responsáveis pela formação de canais intra-citoplasmáticos.

A ativação do sistema complemento culmina com a formação do MAC C5b-9(n) inserido na bicamada lipídica da célula alvo ou com a produção de outra forma solúvel que se apresenta citoliticamente inativa no soro, o complexo SC5b-9. A proteína S, também chamada vitronectina, é um monômero solúvel de $83 \mathrm{kDa}$, que se liga ao complexo C5b-7, inibindo a sua capacidade de associar-se à membrana. Analogamente à proteína $\mathrm{S}$, outro monômero chamado SP40 (clusterina) também inativa o complexo C5b-9(n). 
Tabela 1. Proteínas do Sistema complemento (Morgan, 1990; Morley \& Walport, 2000)

\begin{tabular}{|c|c|c|c|c|c|}
\hline & \multirow[t]{2}{*}{ Componente } & \multirow[t]{2}{*}{$\begin{array}{l}\text { Peso Molecular } \\
(\mathrm{kDa})\end{array}$} & \multirow[t]{2}{*}{ Estrutura - subunidades } & \multicolumn{2}{|c|}{$\begin{array}{l}\text { Concentração } \\
\text { no plasma }\end{array}$} \\
\hline & & & & $m g / L$ & $(\mu M)$ \\
\hline \multirow{5}{*}{ Via Clássica } & $\mathrm{Clq}$ & 460 & $\begin{array}{l}18 \text { cadeias: } 6 \mathrm{~A}(26 \mathrm{kDa}) \\
6 \mathrm{~B}(26 \mathrm{kDa}), 6 \mathrm{C}(26 \mathrm{kDa})\end{array}$ & $\begin{array}{l}100- \\
180\end{array}$ & 0.15 \\
\hline & C1r & 83 & $\begin{array}{l}\text { Cadeia simples, ligada a } \\
\text { C1q }\end{array}$ & 50 & 0.30 \\
\hline & C1s & 83 & $\begin{array}{l}\text { Em plasma formando o } \\
\text { complexo } \mathrm{C} 1 \mathrm{qC} 1 \mathrm{r}_{2} \mathrm{C} 1 \mathrm{~s}_{2}\end{array}$ & 50 & 0.30 \\
\hline & $\mathrm{C} 2$ & 100 & Cadeia simples & 20 & 0.20 \\
\hline & C4 & 205 & $\begin{array}{l}1 \text { cadeia } \alpha(97 \mathrm{kDa}) \\
1 \text { cadeia } \beta(75 \mathrm{kDa}) \\
1 \text { cadeia } \gamma(33 \mathrm{kDa})\end{array}$ & $\begin{array}{l}200- \\
600\end{array}$ & 3.0 \\
\hline \multirow{4}{*}{$\begin{array}{l}\text { Via das } \\
\text { Lectinas }\end{array}$} & MBL & 32 & 2-6 trimeros & $0-5$ & \\
\hline & MASP-1 & 93 & $\begin{array}{l}\text { Cadeia pessada }(66 \mathrm{kDa}) \\
\text { Cadeia leve }(31 \mathrm{kDa})\end{array}$ & 6 & \\
\hline & MASP-2 & 76 & $\begin{array}{l}\text { Cadeia A (52 kDa) } \\
\text { Cadeia B (31 kDa) }\end{array}$ & & \\
\hline & MASP-3 & & & & \\
\hline \multirow{3}{*}{$\begin{array}{l}\text { Via } \\
\text { Alternativa }\end{array}$} & Fator B & 93 & Cadeia simples & 210 & 2.0 \\
\hline & \begin{tabular}{|l|} 
Fator D \\
\end{tabular} & 24 & Cadeia simples & 2 & 0.05 \\
\hline & Properdina & 220 & $\begin{array}{l}4 \text { subunidades identicas } \\
(55 \mathrm{kDa})\end{array}$ & $20-26$ & 0.10 \\
\hline Comum & C3 & 185 & $\begin{array}{l}1 \text { cadeia } \alpha(110 \mathrm{kDa}) \\
1 \text { cadeia } \beta(75 \mathrm{kDa})\end{array}$ & $\begin{array}{l}1000- \\
1500\end{array}$ & 7.0 \\
\hline \multirow{5}{*}{$\begin{array}{l}\text { Via } \\
\text { Terminal } \\
\text { Comum }\end{array}$} & $\mathrm{C} 5$ & 190 & $\begin{array}{l}1 \text { cadeia } \alpha(115 \mathrm{kDa}) \\
1 \text { cadeia } \beta(75 \mathrm{kDa})\end{array}$ & $70-160$ & 0.4 \\
\hline & C6 & 120 & Cadeia simples & 65 & 0.5 \\
\hline & C7 & 110 & Cadeia simples & 55 & 0.5 \\
\hline & $\mathrm{C} 8$ & 150 & $\begin{array}{l}1 \text { cadeia } \alpha(64 \mathrm{kDa}) \\
1 \text { cadeia } \beta(64 \mathrm{kDa}) \\
1 \text { cadeia } \gamma(22 \mathrm{kDa})\end{array}$ & 55 & 0.4 \\
\hline & C9 & 69 & Cadeia simples & 60 & 0.8 \\
\hline \multirow{6}{*}{$\begin{array}{l}\text { Proteínas } \\
\text { Reguladoras } \\
\text { Solúveis }\end{array}$} & C1-INH & 110 & Cadeia simples & 200 & 1.8 \\
\hline & C4bp & 500 & $\begin{array}{l}8 \text { subunidades idénticas } \\
(70 \mathrm{kDa})\end{array}$ & 250 & 0.5 \\
\hline & Fator $\mathrm{H}$ & 150 & Cadeia simples & 450 & 3.0 \\
\hline & Fator I & 80 & $\begin{array}{l}1 \text { cadeia } \alpha(50 \mathrm{kDa}) \\
1 \text { cadeia } \beta(38 \mathrm{kDa})\end{array}$ & 35 & 0.4 \\
\hline & Proteína S & 83 & Cadeia simples & 500 & 6.0 \\
\hline & Sp-40, 40 & 70 & 2 subunidades $(35 \mathrm{kDa})$ & 50 & \\
\hline \multirow{4}{*}{$\begin{array}{l}\text { Proteínas } \\
\text { Reguladoras } \\
\text { de }\end{array}$} & CR1 & $160-250$ & Cadeia simples & & \\
\hline & DAF & 70 & Cadeia simples & & \\
\hline & MCP & $45-70$ & Cadeia simples & & \\
\hline & HRF/MIP & 65 & Cadeia simples & & \\
\hline
\end{tabular}




\begin{tabular}{|c|c|c|c|c|c|}
\hline & \multirow[t]{2}{*}{ Componente } & \multirow[t]{2}{*}{$\begin{array}{l}\text { Peso Molecular } \\
\text { (kDa) }\end{array}$} & \multirow[t]{2}{*}{ Estrutura - subunidades } & \multicolumn{2}{|c|}{$\begin{array}{l}\text { Concentração } \\
\text { no plasma }\end{array}$} \\
\hline & & & & $\mathrm{mg} / \mathrm{L}$ & $(\mu M)$ \\
\hline Membrana & CD59 & 20 & Cadeia simples & & \\
\hline \multirow{5}{*}{ Receptores } & CR2 & 146-148 & Cadeia simples & & \\
\hline & CR3 & 255 & $\begin{array}{l}2 \text { cadeias } \alpha-\text { CD1 } 1 \mathrm{~b}(160 \\
\mathrm{kDa}) \\
1 \text { cadeia } \beta-\mathrm{CD} 18(95 \\
\mathrm{kDa})\end{array}$ & & \\
\hline & CR4 & 245 & $\begin{array}{l}2 \text { cadeias } \alpha-\text { CD11c }(150 \\
\mathrm{kDa}) \\
1 \text { cadeia } \beta-\mathrm{CD} 18(95 \mathrm{kDa})\end{array}$ & & \\
\hline & C3Ar & 54 & Cadeia simples & & \\
\hline & C5aR & $43-55$ & Cadeia simples & & \\
\hline
\end{tabular}




\section{I.5 PROTEÍNA C5}

A proteína C5 é codificada por um gene de $79 \mathrm{~kb}$, compreende 41 éxons com tamanhos que variam de 58 (éxon 33) a 531 nucleotídeos (éxon 41) e possui íntrons com tamanhos que variam de 116 a 5600 nucleotídeos (CARNEY et al., 1991). O gene C5 está localizado no cromossomo 9 humano na posição q32-34 (WETSEL et al., 1988). A expressão deste gene é responsável pela geração da forma precursora (Pró-C5) sintetizada como única cadeia polipeptídica (190 kDa), a qual será processada antes de ser secretada como uma proteína madura formada pelas cadeias $\beta(75 \mathrm{kDa})$ e $\alpha(115 \mathrm{kDa})$ (TACK et al., 1979). A cadeia $\beta$ é codificada pelos éxons $1-16$ e a cadeia $\alpha$ pelos éxons $16-41$. A codificação de C5a é feita pelos éxons 16 e 17. Dependendo do splicing alternativo do gene $C 5$ em humanos, formam-se três transcritos do gene $C 5$, dos quais dois transcritos truncados são encontrados. O transcrito completo (5800 bases) é explicado acima. O transcrito truncado pHC5A (Figura 4) é formado pelo splicing que liga o éxon 20 ao éxon poliadenilado 21 a e compreende a região que vai do éxon 1 ao éxon 21a (2946 aa). O transcrito pHC5B de 2071 aa compreende a região que vai do éxon 1 ao éxon 16 (CARNEY et al., 1991).

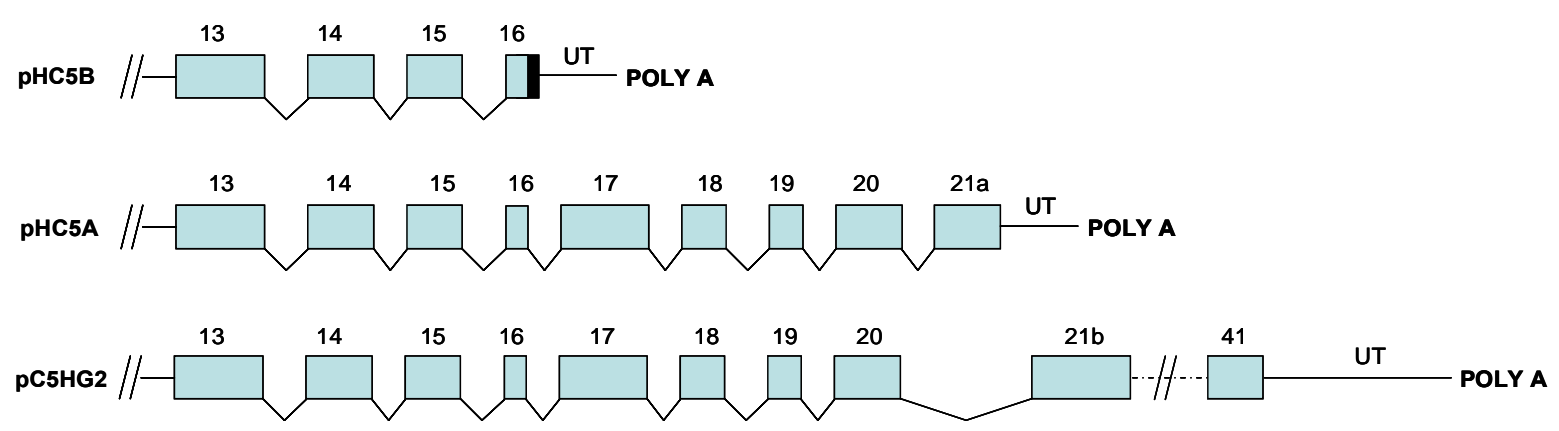

Figura 4. Estrutura de dois transcritos truncados no gene C5 humano (CARNEY et al., 1991). Os éxons estão indicados por caixas, os íntrons por linhas anguladas entre os exones // referese aos éxons e íntron faltantes. 
O componente C5 é uma glicoproteína plasmática de 1666 aa. Ele é formado por duas cadeias polipeptídicas: uma de $115 \mathrm{kDa}($ cadeia $\alpha$ ) e outra de $75 \mathrm{kDa}$ (cadeia $\beta$ ). Essas cadeias estão ligadas entre si por uma ponte dissulfeto (Figura 5). Este componente participa da ativação iniciada por qualquer uma das três vias de ativação e dele dependem diversas funções biológicas importantes para a resposta imune inata e adquirida que serão comentadas mais adiante.

C5 é sintetizado principalmente pelo fígado (COLTEN et al., 1972; GENG et al., 1986) e está presente no plasma em concentração aproximada de 70 a $160 \mu \mathrm{g} / \mathrm{mL}$ (KOHLER \& MÜLLER-EBERHARD, 1967; PFARR et al., 2005). Sua síntese também foi observada no pulmão (ROTHMAN et al., 1989; STRUNK et al., 1988), baço, intestino fetal (COLTEN, 1972), em células inflamatórias como monócitos (WHALEY, 1980; COLE et al., 1982) e macrófagos humanos (COLE et al., 1982; COLE et al., 1983) e em células linfoblastóides T e B nos humanos (REED et al., 1990).

As funções biológicas de C5 dependem da ação de seus fragmentos C5a e C5b, gerados após clivagem de C5 por C5 convertases das vias clássica (SHIN et al., 1971), das lectinas $(\mathrm{C} 4 \mathrm{~b} 2 \mathrm{a} 3 \mathrm{~b})$ e alternativa $(\mathrm{C} 3 \mathrm{bBb} 3 \mathrm{~b})$. Independentemente da origem das $\mathrm{C} 5$ convertases, a cadeia $\alpha(116 \mathrm{kDa})$ é clivada entre a $\operatorname{Arg}^{751}$ e a Leu ${ }^{752}$, gerando o fragmento C5a (11 kDa) e o fragmento C5b formado pela cadeia $\alpha^{\prime}(105 \mathrm{kDa})$ e cadeia $\beta(75 \mathrm{kDa})$ TACK et al. (1979).

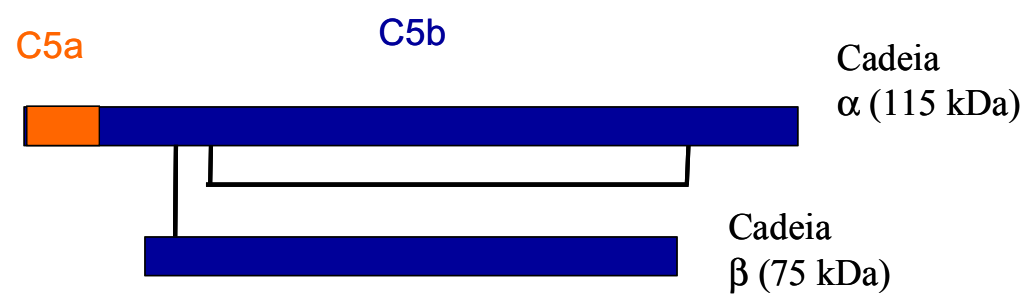

Figura 5. O componente C5 (190 kDa) é uma glicoproteína composta por duas cadeias polipeptídicas: $\alpha(115 \mathrm{kDa})$ e $\beta(75 \mathrm{kDa})$, ligadas entre si por uma ponte dissulfeto. 
Além das C5 convertases conhecidas há bastante tempo, outras enzimas que não fazem parte do sistema complemento podem também igualmente gerar C5a e C5b. HUBERLANG et al. (2002) mostraram que neutrófilos humanos ativados pela presença de C5 produzem uma serino protease, diferente das C5 convertases conhecidas, sendo, por tanto, capazes de gerar C5a. Esse mesmo grupo de pesquisa no ano 2006 mostrou que a enzima trombina do sistema da coagulação pode atuar de maneira similar às C5 convertases tradicionais. Ao analisar a deposição de imunocomplexos no pulmão de camundongos C3 deficientes $\left(\mathrm{C}^{-/-}\right)$e $\mathrm{C} 3$ suficientes $\left(\mathrm{C}^{+/+}\right)$, uma significante produção de $\mathrm{C} 5 \mathrm{a}$ foi observada em camundongos $\mathrm{C}^{-/-}$. A produção de $\mathrm{C} 5 \mathrm{a}$ em ambas as linhagens foi diminuída pela presença de anti-trombina, sugerindo que a trombina seja responsável pela clivagem de $\mathrm{C} 5$ em C5a e C5b HUBER-LANG et al. (2006).

\subsubsection{RECEPTOR para C5a:}

Muitas das funções específicas de C5 dependem da ligação do fragmento C5a ao seu receptor (C5aR). C5aR é membro da superfamília dos receptores para rodopsina. Estruturalmente é formado por sete domínios transmembrânicos (GERARD \& GERARD, 1994). Sua região amino-terminal (1 a 20 aa) liga-se a uma primeira região transmembrânica que por a sua vez liga-se a uma segunda e assim sucessivamente a outras cinco regiões transmembrânicas através de ponte disulfeto (Figura 6), culminando com uma região carboxi terminal (62 a 74 aa). A região amino-terminal contém 7 Asp localizadas nas posições 5, 10, 15, 16, 18 e 21. Anticorpos específicos para esta região bloqueiam a ligação de C5a com seu receptor em diversas células, inibindo as atividades inflamatórias desencadeadas pela ligação C5a-C5aR (MORGAN et al., 1993). O gene C5aR compreende dois éxons localizados no cromossomo 19 posição q13.2 (GERARD et al., 1993). 
O C5aR está localizado na membrana de neutrófilos, monócitos, eosinófilos e macrófagos, assim como nas células do parênquima hepático, nas células vasculares que irrigam os músculos da boca, nas células do epitélio alveolar e bronquial, no pulmão e nas células do sistema nervoso central (HAVILAND et al., 1995).

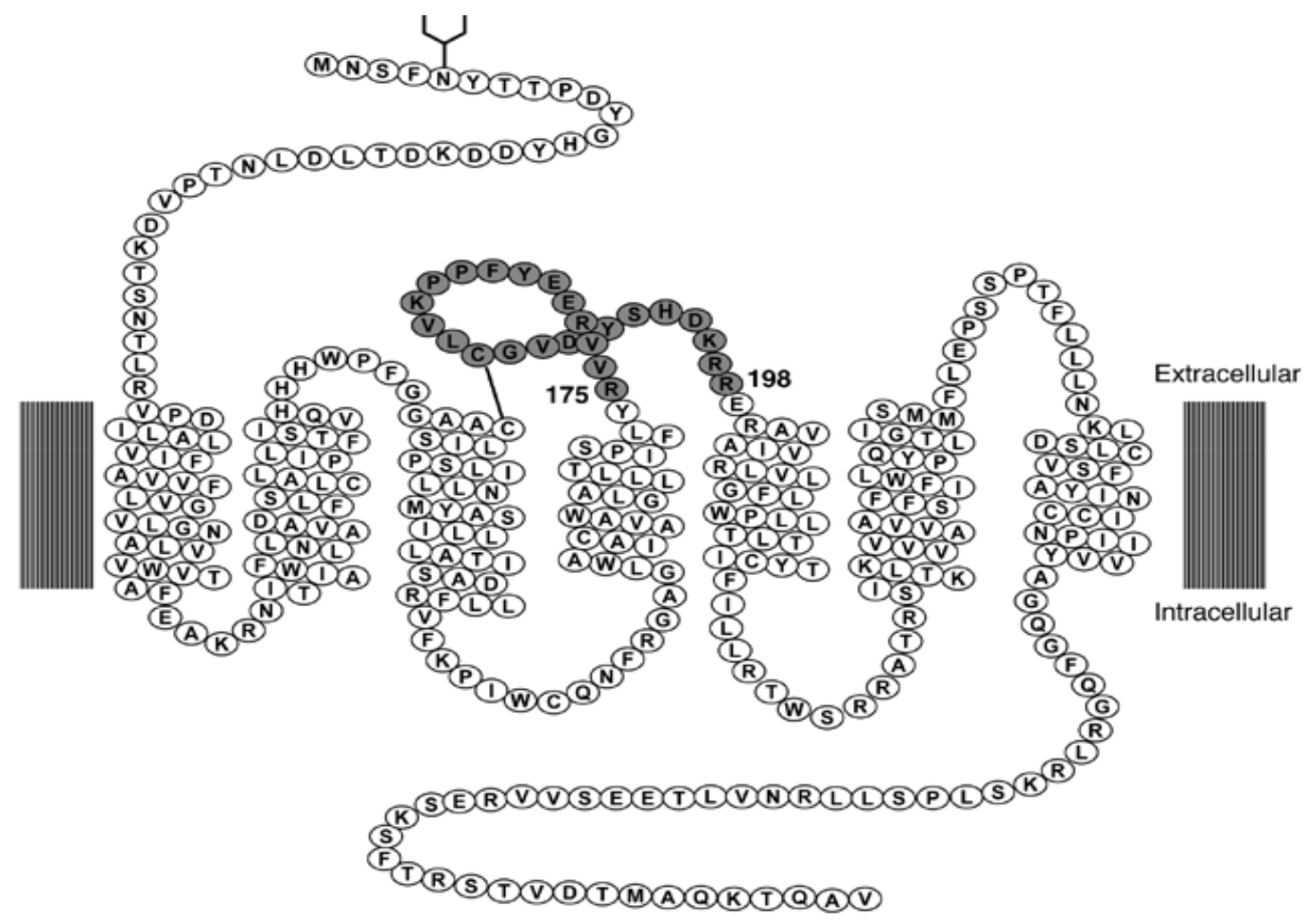

Figura 6. O receptor de $\mathrm{C} 5 \mathrm{a}$, estruturalmente é formado por sete domínios transmembrana. que estão ligadas entre si por seis pontes dissulfeto. 


\subsection{PROTEÍNAS REGULADORAS}

A regulação da ativação do sistema complemento é importante para evitar o consumo desnecessário dos componentes de complemento no soro durante o processo inflamatório o que levaria à posterior incapacidade de ativação do sistema complemento no momento de outra infecção. Além do mais, a regulação da ativação do sistema complemento em nossas próprias células é necessária, caso contrário ocorreria a destruição destas pelo MAC e excesso de mediadores inflamatórios.

\subsubsection{REGULADORES PLASMÁTICOS}

O inibidor de C1 esterase (C1-INH) é uma serinoprotease altamente glicosilada, presente no soro na concentração de $150 \mu \mathrm{g} / \mathrm{mL}$. Para a inativação de proteases (por ex: C1s ou C1r), pelo inibidor de serinoprotease é necessário o reconhecimento e clivagem de um centro reativo na superfície desse inibidor com a posterior ligação dos aminoácidos que formam parte desse centro com as proteases. No momento da ligação, C1r e C1s clivam o C1INH na região $\mathrm{Arg}^{444}-\mathrm{Thr}^{445}$ resultando na formação de um complexo estável formado pelo C1s e C1r e C1-IHN (Figura 7) (SIM et al., 1979). Este fato limita o consumo de C2 e C4 pelo $\mathrm{C} 1$, regulando a ativação da via clássica. C1-INH também regula a ativação da via alternativa mediante a sua ligação com C3b o que inibe a sua posterior ligação com o Fator B, evitando a formação da C3 convertase da via alternativa (JIANG et al., 2001). MATSUSHITA et al. (2000) confirmaram que C1-INH inibia proteoliticamente as formas ativadas de MASP-1 e MASP-2, observando que a atividade proteolítica de MASP-1 contra C3 e C2 eram inibidas de maneira dose-dependente na presença de C1-INH. O mesmo efeito foi observado com MASP-2, onde a clivagem de $\mathrm{C} 4$ e $\mathrm{C} 2$ é inibida de modo dose dependente na presença de C1-INH. 
C4b binding protein (C4BP) é uma proteína plasmática composta por sete cadeias $\alpha$ iguais (Tabela 1) unidas a um centro em comum correspondente à cadeia $\beta$, formando uma estrutura aracnóide. As cadeias $\alpha$ possuem quatro sítios de ligação para $\mathrm{C} 4 \mathrm{~b}$, motivo pelo qual esta proteína apresenta alta afinidade para se ligar ao fragmento $\mathrm{C} 4 \mathrm{~b}$ na fase fluida. GIGLI et al. (1979) isolaram do soro humano de indivíduos normais uma proteína capaz de ligar-se ao fragmento $\mathrm{C} 4 \mathrm{~b}$ do sistema complemento, hoje conhecida como C4BP. C4BP também é capaz de inibir a ligação de $\mathrm{C} 4 \mathrm{~b}$ com a proteína $\mathrm{C} 2$, suprimindo assim a formação da $\mathrm{C} 3$ convertase da via clássica. C4BP ao atuar como co-fator de Fator I, induz a clivagem de C4b formando iC4b, C4c e C4d (Figura 7) (FUJTA et al., 1978).

PILLEMER et al. (1954) mostraram pela primeira vez a existência de uma proteína (hoje conhecida como properdina) que atua conjuntamente com as proteínas do sistema complemento na presença de $\mathrm{Mg}^{+2}$. MARCUS et al. (1971) indicaram que a properdina ajudaria na clivagem de C3. MEDICIUS et al. (1976) provaram que a properdina é capaz de se ligar a C3b, formando o complexo solúvel P-C3 convertase (este complexo inclui Fator B, Fator $\mathrm{D}, \mathrm{C} 3 \mathrm{e} \mathrm{Mg}^{+2}$ ) na membrana dos eritrócitos cobertos por C3b. A presença de properdina aumenta a meia vida da C3- e C5- convertases da via alternativa (Figura 7).

O Fator $\boldsymbol{H}$ é um dos principais reguladores da via alternativa (HARRISON \& LACHMANN, 1980) uma vez que previne a formação e promove a dissociação da C3- e C5convertases $(\mathrm{C} 3 \mathrm{bBb}$ e $\mathrm{C} 3 \mathrm{bBb} 3 \mathrm{~b})$ da via alternativa, mediante a dissociação do Fator $\mathrm{B}$ ou do fragmento $\mathrm{Bb}$ da $\mathrm{C} 3$ convertase e da $\mathrm{C} 5$ convertase da via alternativa. O Fator $\mathrm{H}$ também atua como co-fator do Fator I na clivagem de C3b e iC3b (Figura 7).

O Fator I é um dímero formado por duas cadeias: a cadeia $\alpha$ de $50 \mathrm{kDa}$ e a cadeia $\beta$ de $38 \mathrm{kDa}$ unidas por ponte dissulfeto. Funcionalmente é uma serino-protease que cliva a cadeia $\alpha$ do fragmento $\mathrm{C} 4 \mathrm{~b}$, em dois fragmentos: um maior chamado $\mathrm{C} 4 \mathrm{c}$ e outro menor $\mathrm{C} 4 \mathrm{~d}$. Além disso, quando o Fator I usa como co-fatores o Fator H, MCP ou complement receptor -1 
CR1, cliva a cadeia $\alpha^{\prime}$ de C3b formando iC3b e C3f. Quando o Fator I utiliza como co-fator a CR1, cliva a cadeia $\alpha^{\prime}$ de C3b, formando C3c e C3dg (Figura 7). (MORLEY \& WALPORT, 2000).

\section{I.6.2 REGULADORES ASSOCIADOS À MEMBRANA CELULAR}

A vitronectina (Proteína $S$ ) encontra-se no plasma assim como na superfície de algumas células, tecido conjuntivo e plaquetas, modulando a regulação na formação do complexo ataque à membrana, uma vez que ao se ligar aos complexos C5b-7, C5b-8 e C5b-9 interfere com a polimerização de C9 (Figura 7), inibindo assim a ligação destes complexos à membrana da célula alvo (McLEOD et al., 1974; JENNE et al., 1985). TSCHOPP et al. (1988) mostraram que a vitronectina inibe a formação do complexo de ataque a membrana mediante interações através de ligações com a heparina. O domínio heparina da proteína S se liga a uma região carregada negativamente de $\mathrm{C} 9$, inibindo a polimerização de $\mathrm{C} 9$.

O CR1 (CD35) localizado nas membranas de neutrófilos, eritrócitos, linfócitos B e células dendríticas foliculares, liga-se a $\mathrm{C} 3 \mathrm{~b}, \mathrm{iC} 3 \mathrm{~b}$ e $\mathrm{C} 4 \mathrm{~b}$ com baixa afinidade. Este receptor na presença de Fator I permite a clivagem de C3b e iC3b (FEARON, 1979). Ao se ligar a C4b gera $\mathrm{C} 4 \mathrm{c}$ e $\mathrm{C} 4 \mathrm{~d}$, acelerando o decaimento da $\mathrm{C} 3$ e da $\mathrm{C} 5$ convertase da via clássica (Figura 7) (IIDA \& NUSSENZWEIG, 1983). CR1 atua como receptor para imunocomplexos ou microorganismos opsonizados por $\mathrm{C} 3 \mathrm{~b}$ e $\mathrm{C} 4 \mathrm{~b}$, facilitando a endocitose por células fagocitárias (ver em Remoção dos Imunocomplexos pelo Fígado). YAZDANBAKHSH et al. (2003) avaliaram a habilidade de CR1 solúvel em inibir a lise de eritrócitos humanos e observaram que diversas formas recombinantes truncadas de CR1 (sCR1) têm a capacidade de se ligar a fragmentos $\mathrm{C} 3 \mathrm{~b}$ e $\mathrm{C} 4 \mathrm{~b}$, inibindo assim a formação da C3- e C5 convertase. Empregando um modelo in vitro, estes autores mostraram que as moléculas sCR1 inibiam a formação do MAC e deposição dos fragmentos C3b e C4b na superfície de eritrócitos. Em um modelo in vivo, ao utilizarem camundongos reativos a eritrócitos humanos do grupo A, eles observaram que ao 
receberem transfusão sangüinea deste tipo de eritrócitos a remoção destas células da corrente sangüínea era mediada por anticorpos anti-A. Contudo, a administração de pequenas doses $(1,5 \mathrm{mg} / \mathrm{kg})$ de CR1 prolongava a sobrevida desses eritrócito, sugerindo assim que CR1 poderia funcionar como um inibidor de hemólise dependente de complemento.

Decay Accelerating Factor (CD55) é uma proteína que protege o tecido hospedeiro do dano causado pela ativação do sistema complemento. Localizado nas membranas de eritrócitos, leucócitos, células epiteliais, mas não em células natural killer (NICHOLSONWELLER et al., 1986). Atua de maneira similar à C4BP da via clássica, mas não atua como co-fator de Fator I. Ao se ligar a C4b, evita a ligação de C2 e com isso a formação da C3 convertase da via clássica e das lectinas. Ao evitar a formação da C3 convertase, também inibe a formação da C5 convertase (Figura 7) e com isso a ativação da via terminal comum que gera o MAC.

O CD59 pode ser encontrado no plasma, assim como ancorado na membrana de algumas células como eritrócitos, leucócitos, células do endotélio vascular, brônquios, células renais e na epidermes e no sinciciotrofoblasto da placenta. O CD59 liga-se à membrana da célula via uma âncora de glicosilfosfatidilinositol (GPI), inibindo a formação do MAC (Figura 7), impedindo a ligação de C9 ao complexo C5b-8 (MERI et al., 1990).

A Membrane Cofactor Protein (MCP) está expressa em todas as células circulatórias como granulócitos, linfócitos $\mathrm{T}$, linfócitos $\mathrm{B}$, células $\mathrm{NK}$ (natural killer) e monócitos incluindo plaquetas, mas ausente em eritrócitos. Ao atuar com o Fator I induz a clivagem de C3b e C4b na formação da C3 e da C5 convertases das vias de complemento (Figura 7). Ao contrario do DAF, a MCP não acelera o decaimento das convertases. 


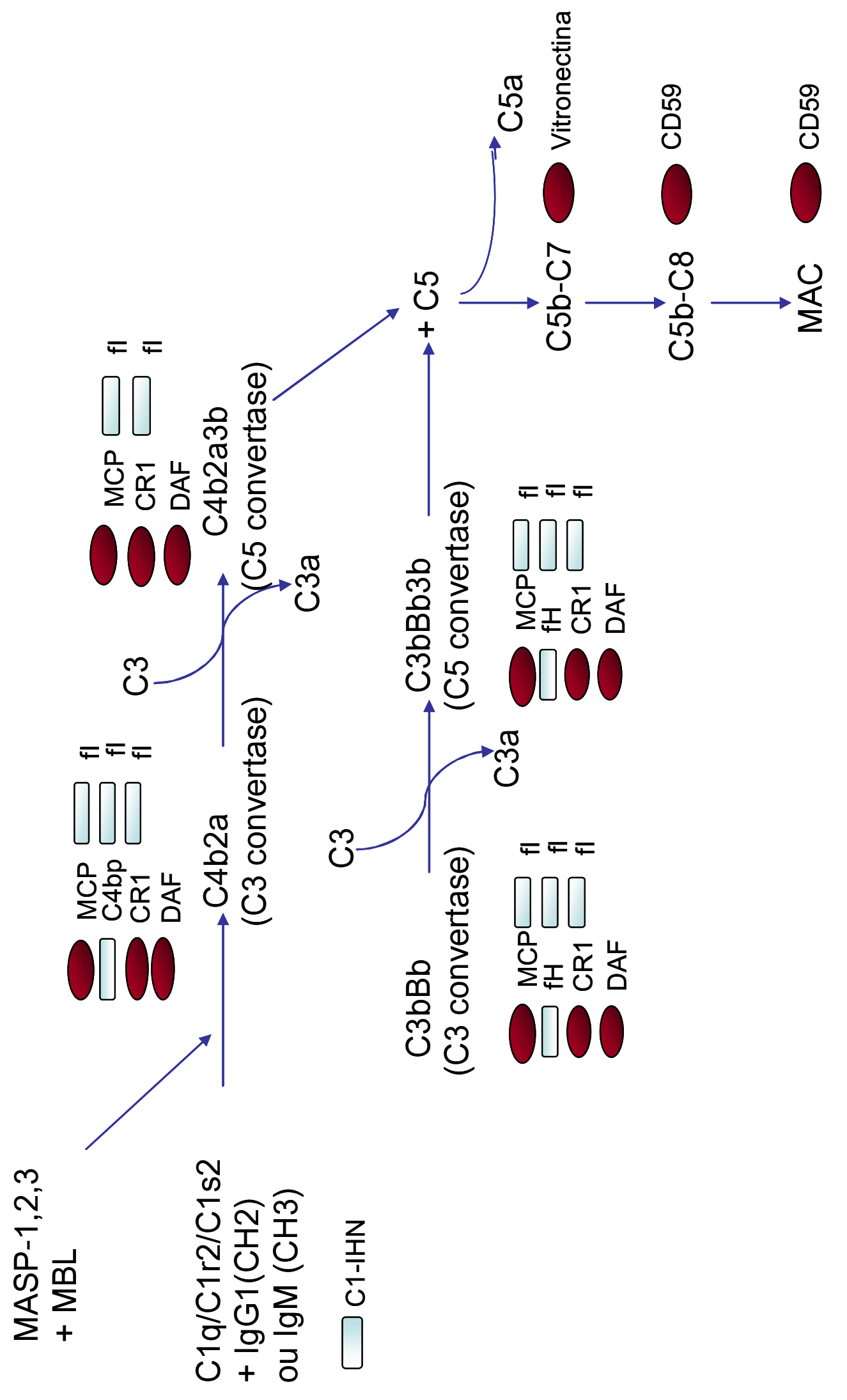




\section{I.7. FUNÇÕES BIOLÓGICAS DERIVADAS DA ATIVAÇÃO DO SISTEMA COMPLEMENTO.}

Várias funções biológicas são geradas após ativação do sistema complemento. Segue abaixo algumas das mais importantes que participam dos mecanismos inatos e adquiridos da resposta imune.

\subsubsection{Formação do MAC}

O MAC C5b-9(1-18), é um dois mais importantes agentes citolíticos do sistema imune inato e adquirido. Este complexo ao inserir-se na bicamada lipídica de células-alvo permite a passagem de água e íons para o interior da célula, causando a lise osmótica (ver Ativação da Via Terminal Comum).

\subsubsection{Produção de Anafilatoxinas}

$\mathrm{Na}$ reação de anafilaxia os mastócitos liberam grânulos de histamina nos tecidos ou órgãos adjacentes a estes. Sabe-se que os fragmentos $\mathrm{C} 5 \mathrm{a}, \mathrm{C} 3 \mathrm{a}$ e $\mathrm{C} 4 \mathrm{a}$ ao se unirem a seus respectivos receptores na membrana dos mastócitos e basófilos, provocam a liberação de histamina e de outros mediadores, causando o aumento da permeabilidade vascular.

GERARD \& GERARD (1994) mostraram que esta molécula pode atuar como uma potente anafilatoxina causando contração muscular, aumento da permeabilidade vascular, desgranulação de mastócitos e basófilos. DAFFERN et al. (1995) mostraram que C5a induz a polarização e ativação em eosinófilos e neutrófilos. A migração mediada por C5a é dez vezes mais potente em eosinófilos do que em neutrófilos, enquanto o fragmento C3a somente ativa eosinófilos. Na atividade enzimática, observou-se que C3a induz a liberação de eosinófiloperoxidase em eosinófilos e C5a induz a liberação de eosinófilo-peroxidase e de $\beta$ glucuronidase em ambas as células. TAKABAYASHI et al. (1996) mostraram que os 
fragmentos $\mathrm{C} 3 \mathrm{a}$ e $\mathrm{C} 3 \mathrm{a}_{\text {desARG }}(\mathrm{C} 3 \mathrm{a}$ clivado pela enzima carboxipeptidase $\mathrm{N}$ ) podem aumentar a síntese de tumour necrosis factor- $\alpha$ (TNF- $\alpha$ ) e interleukin-1 $\beta$ (IL-1 $\beta$ ) por monócitos aderentes em sítios inflamatórios e inibir a síntese das mesmas em células circulantes. Desta forma, estes fragmentos poderiam ter um papel modulador na inflamação.

\subsubsection{Opsonização}

O processo de opsonização envolve o reconhecimento de partículas que cobrem diversos organismos ou antígenos por receptores específicos presentes na célula fagocítica. A formação desta ligação envolve mecanismos nesta célula, que culminam na ingestão e digestão do antígeno que foi coberto. Moléculas que cobrem estes organismos e facilitam a fagocitose são chamadas de opsoninas. As opsoninas formadas durante a ativação do sistema complemento: C3b, iC3b e C4b, são reconhecidas pelos receptores CR1 (C3b e C4b) e CR3 (iC3b). EHLENBERGER \& NUSSENZWEIG (1977) demonstraram pela primeira vez a função de um receptor de complemento na fagocitose. Quando trataram eritrócitos com IgG ou com $\mathrm{C} 3$ ou com $\mathrm{IgG}+\mathrm{C} 3$ para empregarem em experimentos de fagocitose por células polimorfonucleares $(\mathrm{PMN})$, estes autores observaram que $\mathrm{C} 3$, por si só, não induzia a ingestão. Para induzir uma boa ingestão por parte dos neutrófilos eram necessárias 60000 unidades de $\mathrm{IgG}$ por eritrócito, mas na presença de C3 este número diminuiu para 6000 . Demostraram na ligação do receptor de C3b (CR1) presentes nos monócitos, neutrófilos e outras células PMN com C3b na membrana dos eritrócitos, a cooperação do $\mathrm{Fc} \gamma \mathrm{R}$ ligado a IgG na membrana dos eritrócitos é requerida para induzir a ingestão. Estabeleceram assim que a função de C3 com seu receptor na opsonização é aumentar o contacto entre o fagócito e a partícula a ser fagocitada. BAJTAI et al. (2004) encontraram que a célula dendrítica imatura derivada de monócito (imMDC) expressa maior concentração das moléculas que constituem parte do CR3 (CD11b e CD18), quando comparado com células dendriticas maduras. 
Ao opzonizar particulas de HIV-1 com C3 e imunoglobulinas (IgG), observou-se que a infecção de monócitos e macrófagos com HIV era facilitada pelo reconhecimento via CR3. PRUENSTER et al. (2005) reafirmou este conceito. Os fragmentos de C3 (C3c e C3d), uma vez formados, depositam-se sobre as cápsides das partículas de HIV recém-sintetizadas e liberadas pelas células dendríticas hospedeiras. Em um experimento in vitro, mostrou-se que o vírus $\mathrm{HIV}$ ao ser cultivado com $\mathrm{C} 3 \mathrm{c} / \mathrm{C} 3 \mathrm{~d}$ apresentava uma forte ligação com células dendríticas imaturas via CR3. Esta ligação e posterior fagocitose provoca a infecção da célula hospedeira. A infecção provocada nesta célula pelas partículas de HIV opsonizadas é duas vezes maior se comparada com as partículas não opsonizadas. Se estas partículas de HIV opsonizadas com C3 forem neutralizadas com anti-CR3, a ligação e posterior fagocitose do vírus por parte das células dendríticas diminui em 50\%, quando comparada com o vírus que não foi neutralizado com anti-CR3.

Outras proteínas do complemento que também funcionam como opsoninas são C1q e MBL (NAUTA et al., 2004). Ao se incubar células dendríticas imaturas com células apoptóticas opsonizadas por $\mathrm{C} 1 \mathrm{q}$, estes autores observaram a presença de células duplo positivas (células dendríticas que se ligam a células apoptóticas via C1q) de maneira tempo dependente a $37^{\circ} \mathrm{C}$. Esta propriedade também foi observada em macrófagos que ingerem células apoptóticas opsonizadas com MBL. A ingestão de células apoptóticas opsonizadas pelas células dendríticas imaturas ou pelos macrófagos depende da concentração de C1q e de MBL. As células dendríticas e os macrófagos expressam na sua superfície receptores para C1q (C1qR). NAUTA et al. (2004) mostraram que a interação da células dendríticas com C1q-célula apoptótica estimulava a síntese de IL-6, IL-10 e TNF e diminuía a síntese de IL12 p70 pelas células dendríticas. Concluíram que a opsonização de células apoptóticas com C1q e MBL favorece a fagocitose por parte das céuluas dendríticas, sendo esta função 
importante para evitar o reconhecimento de auto-antígenos e desenvolvimento de resposta auto-imune.

TAYLOR et al. (2004) determinaram in vivo pela primeira vez a contribuição das proteínas C1q e C4 na ativação, recrutamento e fagocitose de células apoptóticas por macrófagos murinos residentes ou inflamatórios. Recentemente, nosso grupo demonstrou que células dendríticas originadas a partir de monócitos são capazes de expressar várias proteínas como C3, C5, C9, Fator I, Fator H, Fator B, Fator D e properdina em níveis semelhantes aos observados com macrófagos. O tratamento de células dendríticas com lipopolissacarídeo promoveu um aumento na expressão de RNAm de C3 e de Fator I, entretanto diminuiu a expressão do mensageiro de C5, enquanto os níveis de RNAms das proteínas acima não foram afetados (REIS et al., 2006a). Nessa mesma linha, foi também observada a expressão aumentada de C6, C7, C8, CR1 e C4BP (REIS et al., 2006b) por estes dois tipos celulares.

\subsubsection{Função Quimiotática}

A quimiotaxia é um processo pelo qual as células são induzidas a migrar em direção a moléculas atrativas. Moléculas com esta qualidade são chamadas de fatores quimiotáticos. No processo inflamatório, os neutrófilos possuem a habilidade de responder a estas moléculas iniciando o influxo destas células ao foco inflamatório, o que culmina com a resolução deste processo. FERNANDEZ et al. (1978) foram os primeiros a demostar in vivo que o componente C5a estimula a migração de neutrófilos (ver em Funções de Complemento Mediadas por C5). 


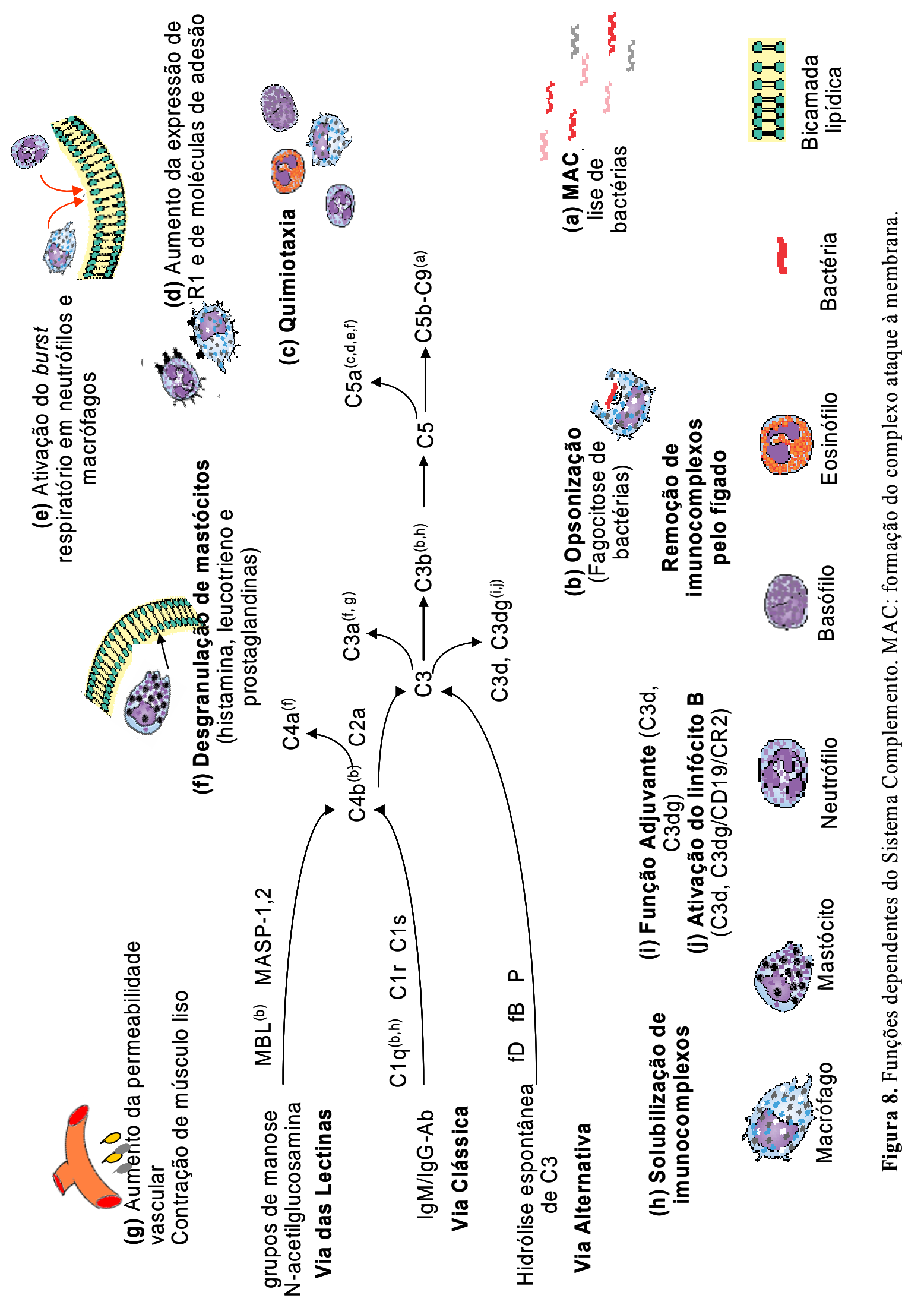




\subsubsection{Solubilização e Transporte de Imunocomplexos}

MILLER \& NUSSENZWEIG (1975) mostraram que proteínas sericas eram capazes de solubilizar imunocomplexos. Essa solubilização era dependente da concentração do soro, presença de $\mathrm{Ca}^{+2}$ e $\mathrm{Mg}^{+2}$ e de $\mathrm{C} 3$, uma vez que ao utilizar anti-C3, formavam-se precipitados de Ag-Ac. FUJITA et al. (1977) mostraram que as proteínas C1 e C3b interferiam na formação da rede de antígeno-anticorpo, o que favorecia a sua solubilização e impedia seu depósito como agregados insolúveis dentro dos tecidos. Isso é particularmente importante, pois imunocomplexos circulantes são potencialmente danosos, já que ao depositarem nas paredes vasculares, ativa o complemento e provoca reações inflamatórias que lesionam os tecidos locais e circunjacentes.

\subsubsection{Remoção dos Imunocomplexos pelo Fígado}

Cerca de 90\% das moléculas de CR1 na circulação estão presentes nos eritrócitos e complexos imunes cobertos por C3b são rapidamente ligados aos eritrócitos via CR1, prevenindo a sua precipitação. Eritrócitos transportam estas redes de imunocomplexos até o fígado e baço, onde fagócitos residentes destes órgãos são encarregados da remoção destas redes da superfície dos eritrócitos para a sua posterior internalização e fagocitose, antes de voltarem a circular (MEDOF et al., 1983). Se não ocorrer esta remoção, estes agregados insolúveis formados por antígenos próprios ligados a auto-anticorpos poderiam se depositar em diversos tecidos, iniciando um forte processo inflamatório que culminaria com dano tecidual.

HELMY et al. (2006) estudaram as propiedades de um novo receptor "CRIg" expressado em monócitos (humanos) e nas células de Küpffer (humanas e murinas). Este receptor tem a capacidade de ligar-se aos fragmentos $\mathrm{iC} 3 \mathrm{~b}$ e $\mathrm{C} 3 \mathrm{~b}$ ligados a superfície de patógenos como Listeria monocytogenes e Staphylococcus aureus, favorecendo assim a 
opsonização e a fagocitose. Em camundongos deficientes (CRIg $\left.{ }^{-/-}\right)$infectados intravenosamente com Listeria monocytogenes, observou-se uma falha na fagocitose destes patógenos quando opsonizados por fragmentos de C3 na circulação, dos pulmões e do fígado, acompanhados pelo aumento da mortalidade. Os autores mostraram assim que CRIg presente na membrana das células de Küpffer intervem na fagocitose e contribui para a rápida remoção de patógenos circulantes.

\subsubsection{Ativação dos linfócitos $B$ e geração de memória imunológica}

EDEN et al. (1973) mostraram que populações de linfócitos B possuem na sua membrana receptores para os fragmentos C3b e C3d. PEPYS (1974) demonstrou que a depleção de C3 em camundongos previamente sensibilizados por eritrócitos de carneiro, diminui a síntese de IgG específicos tanto na resposta primária quanto secundária timodependente.

KLAUS \& HUMPHREY (1977) observaram que camundongos timectomizados imunizados com dinitrofenil haemocianina e logo depletados da proteína C3 pelo tratamento com CoF (cobra venom factor) falhavam no desenvolvimento de linfócitos B de memória, quando comparados com camundongos que não sofreram de depleção da proteína C3. Estes resultados demonstraram assim que a proteína C3 é necessária para a geração normal de linfócitos B de memória. ERDEY et al. (1985) investigaram a ativação de linfócitos murinos esplênicos em cultura com C3, encontrando que C3 assim como LPS induzia a proliferação e a ativação (avaliado pela secreção de imunoglobulinas) dos linfócitos B. MELCHERS et al. (1985) notaram que esta ativação era devida ao fragmento C3d que se ligava ao linfócito B. KLAUS \& HUMPHREY (1986) mostraram que ligação de CR2 com o fragmento C3dg, previamente ligado ao antígeno apresentado pela célula dendrítica folicular, não somente induzia a ativação e diferenciação dos linfócitos B, como também induzia o desenvolvimento 
de centros germinativos. CARTER \& FEARON (1992) mostraram que o complexo formado pelas moléculas CD19/CR2, CD81 e IgM (BCR) presentes na membrana dos linfócitos B reduzia em dez vezes a concentração de antígenos requeridos para a ativação dessas células. AHEARN et al. (1996) mostraram que animais geneticamente modificados $[\mathrm{cr} 2 / \mathrm{cr} 1]^{-/-}$ possuem níveis reduzidos de $\operatorname{IgG} 2 \mathrm{a}, \operatorname{IgG} 2 \mathrm{~b}$ e $\operatorname{IgG} 3$, que resulta em uma diminuição da resposta humoral contra antígenos T-dependentes, levando a uma falha na formação de centros germinativos.

\subsubsection{Função Adjuvante}

Os antígenos cobertos pelos fragmentos C3d e C3dg são mais imunogênicos. Antígeno recoberto por C3d liga-se concomitantemente à $\operatorname{IgM}$ de superfície e aos receptores CD21/CD35 expressos na superfície dos linfócitos B, desencadeando uma forte resposta imune. DEMPSEY et al. (1996) empregaram uma proteína recombinante HEL (lisozima do ovo da galinha) sozinha ou ligada com uma, duas ou três unidades de $\mathrm{C} 3 \mathrm{~d}$, quando encontraram que quanto maior o número de fragmentos $\mathrm{C} 3 \mathrm{~d}$ ligados ao antígeno, maior é a ativação dos linfócitos B e menor é o limiar de antígenos necessários para a produção de anticorpos específicos. HAAS et al. (2004) encontraram que camundongos CD21/CD35 $5^{-/-}$ imunizados com estreptoavidina (SA) ligada a tetrâmeros de C3dg, mostravam uma forte resposta humoral primária e secundária avaliadas pela síntese de IgG e IgM respectivamente em mais de 10000 vezes comparada com camundongos CD21/CD35 $5^{-/}$que só foram imunizados com SA. Em outro experimento, imunizaram camundongos $\mathrm{CD} 21 / \mathrm{CD} 35^{-/-} \mathrm{com}$ a proteína gp120 de HIV ligada a trímeros de C3d, que acabaram por gerar uma forte resposta humoral primária aumentando 150 vezes a produção de IgG comparada com camundongos que só receberam a proteína gp120. Estes dados conjuntamente mostraram que C3dg e C3d 
funcionam como uma molécula adjuvante já que a resposta primária e secundária foi incrementada mesmo na ausência de CD21/CD35.

\subsection{FUNÇÕES BIOLÓGICAS DERIVADAS DA PROTEÍNA C5}

Com a clivagem de C5 em C5a e C5b, várias funções biológicas são geradas e serão descritas a seguir:

\subsubsection{Formação do MAC}

O fragmento C5b apresenta característica hidrofóbica que lhe permite aderir a diversas superfícies celulares e a ele as demais proteínas da via terminal comum C6, C7, C8 e até 18 unidades de C9 se ligam seqüencialmente até formar o MAC, responsável pela lise celular graças a um desbalanço osmótico responsável pelo aumento do volume celular e ruptura celular.

SPRONG et al. (2003) avaliaram a atividade bactericida dependente de C5 em infecção causada por Neisseria meningitidis. em pacientes defiecientes de C5.estes individuos apresentam falha na lise de bactérias como Neisseria sp., S. pneumoniae e $H$. influenzae evidenciando a importância de estúdos que avaliem a participação de C5b na formação do MAC nestas bactérias. Suspensões de N. meningitidis do tipo H44/76 foram misturadas com sangue tratado com anticoagulante ou com PBS, pré-incubando-se por 5 min a $37^{\circ} \mathrm{C}$ (controle) ou com anticorpos (anti-C5 ou anti-C5a). Das alíquotas colectadas, observou-se que quando as bactérias eram incubadas com anti-C5a e com PBS a atividade bactericida foi total. Ao contrário, quando a amostra foi incubada com anti-C5, observou-se uma atividade bactericida contra $N$. meningitidis inferior a $30 \%$, o que reafirma a importância do fragmento C5b na formação do MAC sob a superfície desta bactéria. 


\subsubsection{Atividade Quimiotática}

O fragmento C5a apresenta propriedade quimiotática responsável pela atração ao foco inflamatório de diferentes células polimorfonucleares. WARD \& NEWMAN (1969) foram os primeiros a demonstrar in vitro que neutrófilos de coelho mostravam uma forte resposta migratória ao serem estimulados com $\mathrm{C} 5$ tratado com tripsina produzindo $\mathrm{C} 5 \mathrm{a}$ e $\mathrm{C} 5 \mathrm{~b}$, sendo esta resposta dose e tempo dependentes. TAUBMANN et al. (1970) demonstraram que enzimas lisossomais ao serem misturadas com C5 purificado também geravam atividade quimiotática. NILSSON et al. (1975) mostraram que a tripsina, à semelhança da C5 convertase da via clássica, cliva a cadeia $\alpha$ da proteína C5 gerando C5a. SNYDERMAN et al. (1975) demonstraram ausência de atividade quimiotática sobre macrófagos expostos a soro C5 deficiente. FERNANDEZ et al. (1978) corroboraram os achados de WARD \& NEWMAN (1969), mas empregando desta vez C5a purificado, mostrando assim que este fragmento seria capaz de atrair células para o foco inflamatório.

A atividade quimiotática de C5a não é somente observada na migração de monócitos, eosinófilos e neutrófilos durante a inflamação, mas também induz a migração de linfócitos B humanos. OTONELLO et al. (1999) mostraram que linfócitos B isolados de tonsilas de camundongos apresentavam uma forte polarização e migração, quando expostos a diferentes concentrações de rC5a em câmara de Boyden. Ao dividir esta população de linfócitos B pelo seu estado de maturidade, encontrou-se que os linfócitos $\mathrm{B}$ de memória migravam mais quando expostos ao rC5a, em comparação com os linfócitos B virgens e os linfócitos B do centro germinativo. Empregando citometria de fluxo, constatou-se que linfócitos B de memória expressam 33-47\% de C5aR na sua superfície, os linfócitos B virgens expressam de 10-14\% e os linfócitos B do centro germinativo não exibem C5aR, o que sugere que a migração deve-se à ligação de C5a ao seu receptor encontrado na superfície das diferentes populações de linfócitos B. 
GRANT et al. (2002) empregando um modelo inflamatório in vivo, induziram artrite reumatóide nos joelhos de camundongos $(\mathrm{BALB} / \mathrm{c})$ após injeção de um coquetel composto por quatro tipos de anticorpos específicos para o fragmento CB11 de colágeno tipo II. Observaram que camundongos $\mathrm{C} \mathrm{aR}^{-/-}$não apresentavam danos ocasionados pela artrite, quando comparados com os camundongos $\mathrm{C} \mathrm{aR}^{+/+}$que desenvolvem todos os processos da artrite. Os joelhos dos camundongos $\mathrm{C} \mathrm{aR}^{+/+}$apresentam altíssimos níveis na expressão (RNAm) de IL-1 beta, de metaloproteinase 3 (MMP-3), do ligante de osteoprotegerina que estimula a diferenciação dos osteoclastos e dos marcadores CD4 e CD68 (marcadores específicos de linfócitos $\mathrm{T}$ e de macrófagos respectivamente). Os joelhos dos camundongos

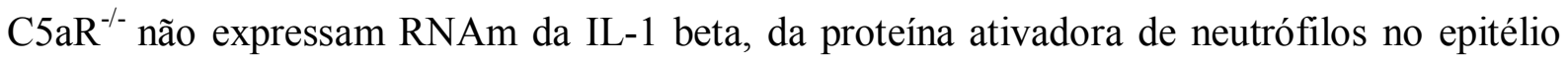
(ENA-78), da proteína inflamatória do macrófago (MIP-1 alfa) e das proteínas VCAM-1 e Eselectina. Motivo pelo qual nestes camundongos diminuem o rolamento e posterior influxo de neutrófilos, a proliferação de fibroblastos e destruição de cartilagens e ossos neste modelo inflamatório.

\subsubsection{Aumento da Explosão Respiratória}

O complemento medeia a ativação de diversas células polimorfonucleares, causando nestas a ativação da explosão respiratória com a conseqüente liberação de espécies reativas de oxigênio $\left(\mathrm{H}_{2} \mathrm{O}_{2}\right.$ e $\left.\mathrm{O}^{-2}\right)$, de citocinas, de enzimas lisosomais, de ácido araquidônico e de histamina. WYMANN et al. (1987) observaram que neutrófilos estimulados com antagonistas de $\mathrm{C} 5 \mathrm{a}$ produziam grandes quantidades de $\mathrm{H}_{2} \mathrm{O}_{2}$ e que esta resposta não está relacionada com

o consumo de $\mathrm{Ca}^{+2}$ intracelular nos neutrófilos, mas sim com a ligação de C5a com seu receptor. EHRENGRUBER et al. (1994) ativaram neutrófilos humanos com os fragmentos C3a e C5a, observando que C3a também ativa neutrófilos, mas esta resposta é passageira. Comparando os dois fragmentos, encontraram que a resposta dos neutrófilos é 100 vezes mais 
potentes, quando estimulados com C5a.

MOLNESS et al. (2002) estudaram o papel do complemento na indução da explosão respiratória em granulócitos e monócitos durante a resposta inflamatória induzida com E. coli, encontrando que a indução da explosão respiratória é três vezes maior em granulócitos que em monócitos. Quando estas células foram incubadas com sangue humano, E. coli e compstatina (aminoácido cíclico que inibe a clivagem de C3 e portanto a geração de C5a) a indução da explosão respiratória foi inibida. Mas ao utilizar anti-C5 humano ou anticorpo monoclonal anti C5a no lugar de compstatina, estes autores observaram uma diminuição de 70\% na explosão respiratória nos granulócitos e 50\% nos monócitos. Antagonistas de C5aR causaram o mesmo efeito nestes tipos celulares. Sendo a explosão respiratória e a fagocitose dois eventos íntimos e contínuos nessas células, estes autores mostraram que a síntese de uma das cadeias do receptor para C3 (CD11b) diminuía aproximadamente 2000 vezes, a explosão respiratória em 3 vezes e a fagocitose em cerca de 600 vezes para granulócitos e 250 vezes para monócitos, quando tratados com este antagonista de C5aR. Estes dados sugerem que C5a exerça um papel importante na indução da explosão respiratória e fagocitose neste modelo experimental.

\subsubsection{Regeneração Tecidual}

A proteína C5a ajuda no influxo e ativação de células polimorfonucleares as quais, por sua vez, contribuem para uma forte resposta inflamatória que causa inicialmente lesão tecidual em um primeiro momento e culmina com a recuperação deste mesmo tecido, após eliminação do agente patogênico.

\subsubsection{Ativação da Produção de Citocinas}

A união de C5a com C5aR também ativa a síntese de IL-6, o que contribui ao 
estabelecimento do processo inflamatório, conforme mostrado por RIEDEMANN et al. (2003). Estes pesquisadores investigaram o papel de C5a na resposta inflamatória, mediante a indução de um estado inflamatório por punctura e ligação de $2 / 3$ do ceco (porção inicial do intestino grosso) no abdome de camundongos da linhagem C57B6 e 1/3 do ceco em ratos (Long Evans) nestas condições os autores observaram que a secreção in vitro de IL-6 por neutrófilos isolados dos ratos controle aumentou 5,5 vezes ao serem estimulados por $4 \mathrm{~h}$ com LPS e C5a, quando comparada com neutrófilos estimulados somente por $2 \mathrm{~h}$. Entretanto, os ratos depletados de neutrófilos ou injetados com anti-C5a diminuíram 4 vezes a síntese de IL6. Em neutrófilos de ratos estimulados com LPS e C5a em presença de um inibidor para NF$\mathrm{k} \beta$, para MEK 1/2, e para p38, observou-se inibição da síntese de IL-6, sugerindo que na transcrição de IL-6 há participação de uma via de sinalização dependente de NF-k $\beta, M E K 1 / 2$ e p38. A ligação de C5a com seu receptor (C5aR) e de LPS com (TLR-4) Toll like receptor 4 ativa as vias de sinalização dependentes de MEK1/2 e p38 respetivamente, que induzem a transcrição e posterior síntese de IL-6 nos neutrófilos.

Observou-se anteriormente (RIEDEMANN et al., 2003) que a resposta inflamatória induzia uma grande síntese de citocinas (IL-1 beta, TNF-alfa e IL-6), as quais, por sua vez, ativam diversas células como: neutrófilos, eosinófilos e macrófagos a produzir outras citocinas (TNF-alfa, IL-12), e diversas moléculas (VCAM, E-selectina, MMP-3, ENA-78, MIP-alfa, EPO e beta-galactosidase) o que permite potencializar a resposta inflamatória.

C5 além de participar da resposta imune inata, pode também estar envolvido na regulação da resposta imune adquirida, uma vez que HAWLISCH et al. (2005) mostraram que C5a tem um efeito negativo na resposta imune induzida por TLR-4. Em macrófagos ativados e estimulados com LPS e C5a observou-se a diminuição da síntese de todas as subunidades da família de IL-12 (IL-12p70, IL-23 e IL-27), sendo esta diminuição dosedependente. Este bloqueio da expressão de IL12p70 dá-se pela inibição do fator de transcrição ERK 1/2. A 
citocina IL-12 induz ativação das células NK e síntese de IFN-gama por linfócitos CD8 ${ }^{+}$. Esta citocina ativa macrófagos e induz a polarização dos linfócitos $\mathrm{T}$ helper 0 a $\mathrm{T}$ helper 1 , mostrado experimentalmente in vitro e in vivo em animais infectados com Leishmania major, já que camundongos C5 deficientes têm uma polarização diminuída dos linfócitos $\mathrm{T}$ helper 0 a linfócitos $\mathrm{T}$ helper 1, quando comparados com os camundongos $\mathrm{C} 5$ suficientes (HAWLISCH et al., 2005).

\subsubsection{Regeneração de Órgãos e Tecidos}

STREY et al. (2003) mostraram que camundongos C3 suficientes e C5 suficientes que haviam sido parcialmente hepatomizados $(\mathrm{pHx})$ iniciavam a etapa de regeneração hepática mediante o consumo de 5-bromo 2- deoxiuridina ("BrdU", marcador corado que se deposita no núcleo dos hepatócitos) 36 h depois da operação, contudo, camundongos $\mathrm{C} 3^{-/-}$e $\mathrm{C} 5^{-/-}$, após cirurgia no fígado, apresentavam uma resposta regenerativa anormal, observando-se nos cortes histológicos do fígado destes camundongos, áreas necrosadas, assim como baixo consumo de BrdU nos hepatócitos desses camundongos $\mathrm{C} 3-$ e $\mathrm{C} 5$ deficientes $\left(\mathrm{C}^{-/-}\right.$e $\left.\mathrm{C}^{-/-}\right)$, indicando menor proliferação destas células comprovada pela diminuição na pesagem dos fígados dos camundongos mortos 44 h depois da operação. Entretanto, a adição de C3a e C5a reverteu o dano ocasionado ao tecido, aumentando significativamente a síntese de DNA por hepatócitos, evidenciado pelo consumo de BrdU e regeneração do tecido hepático depois da extração parcial do fígado.

\subsubsection{Ativação de Linfócitos $T$}

KIM et al. (2004) mostraram que C5aR também induzia a geração e ativação de linfócitos $\mathrm{T} \mathrm{CD}^{+}$, potencializando assim a atividade citotóxica em uma infecção viral in vivo. Para isso, empregaram camundongos selvagens que foram infectados com o vírus da influenza X31 (vírus recombinante tipo A). Estes camundongos foram divididos em três 
grupos: o primeiro foi tratado com um peptídeo antagonista de C5aR; o segundo foi tratado com compstatina que ao se ligar a C3 falha na inibição e clivagem de C3 e por tanto inibe a geração de C5a, e por último o terceiro grupo que não recebeu qualquer tratamento. Estes autores observaram que os camundongos tratados com o antagonista de C5aR apresentavam uma diminuição na expansão de linfócitos T CD8+ específicos para o peptídeo $\mathrm{NP}_{366^{-374}}$ do vírus da influenza no pulmão, comparados com os outros tratamentos. Após análise por citometria de fluxo, constatou-se que os linfócitos T CD8+ dos camundongos tratados com o antagonista de C5aR, apresentavam menor síntese de interferom-gamma (3 vezes menor), comparada com os camundongos do segundo e terceiro grupos. O IFN-gama é uma citocina capaz de aumentar o potencial microbicida e expressão de moléculas de classe I e II do complexo principal de histocompatibilidade em macrófagos. Também se demonstrou que C5a ativa a capacidade citolítica dos linfócitos T CD8+ sobre células infectadas com o peptídeo da influenza (KIM et al., 2004).

\subsection{IMUNODEFICIÊNCIAS PRIMÁRIAS}

As imunodeficiências primárias ou PIDs (do inglês - primary immunodeficiency diseases) constituem um grupo de doenças causadas por algum defeito no sistema imunológico responsável por maior susceptibilidade infecções graves e/ou desenvolvimento de autoimunidade.

No ano de 1970 a Organização Mundial de Saúde convocou em Genebra a primeira reunião para classificar as PIDs. Desde então a cada dois anos este comitê atualiza as informações sobre as PIDs. Na última reunião da Organização Mundial da Saúde ocorrida em Budapeste (Hungria) em 2006 mais de 120 PIDs foram. Nas Tabelas 2, 3 e 4 algumas delas estão apresentadas (NOTARANGELO et al. 2005). 
Um indivíduo que sofre de:

-Inexplicáveis infecções recorrentes

-Infecções com patógenos oportunistas

- Falha no tratamento com antibióticos

é suspeito de sofrer PIDs

A família tem história de PIDs

Estes indivíduos têm algum outro

motivo para sofrer destas infecções

como asma alergia, infecção pelo

HIV, fibrose cística ou outras

anormalidades?

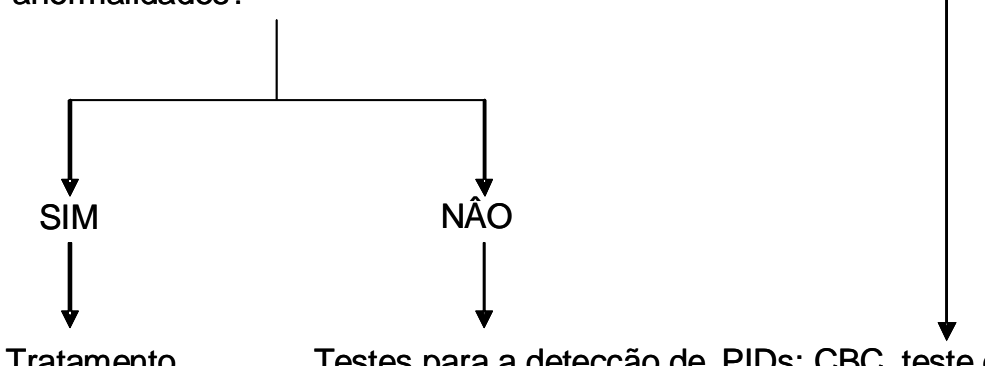

Tratamento

Testes para a detecção de PIDs: CBC, teste de hipersensibilidade,

correspondente

avaliação da concentração de imunoglobulinas ( $\lg G$, $\lg M$ e $\lg A$ ),

teste de anticorpos específicos depois da vacinação, ensaio

hemolítico

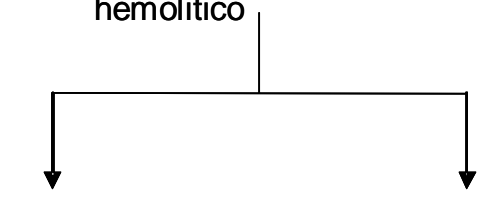

Normal

Abnormal

Diagnóstico de imunodeficiência primária ( PIDs):

Deficiência Imune Celular : diminuição na população de linfócitos T e/ou B. Deficiências de Anticorpos : diminuição da população de linfócitos B com ou sem diminuição dos níveis de IgG.

Síndrome de Wiskott-Aldrich: decréscimo de plaquetas.

Deficiências de Proteínas de Complemento : falha na atividade hemolítica

Figura 9. Etapas a serem seguidas na avaliação de um indivíduo com suspeita de imunodeficiência primária (COOPER et al., 2003). HIV: vírus da imunodeficiência humana, $\mathrm{CBC}$ : contagem total de células sangüíneas. PID imunodeficiência primária. 
Tabela 2. Imunodeficiências combinadas de linfócito T e/ou linfócito B (NOTORANGELO et al., 2005)

\begin{tabular}{|c|c|c|c|c|c|}
\hline Doença & \begin{tabular}{|l}
$\begin{array}{l}\text { Linfócito } \\
\text { circulante }\end{array}$ \\
\end{tabular} & \begin{tabular}{|l|}
$\begin{array}{l}\text { Linfócito } \\
\text { circulante }\end{array}$ \\
\end{tabular} & Ig sérica & \begin{tabular}{|l|}
$\begin{array}{l}\text { Características } \\
\text { associadas }\end{array}$ \\
\end{tabular} & Herança \\
\hline $\begin{array}{l}\mathbf{T}^{-/-} \mathbf{B}^{+/+}, \text {SCID } \\
\gamma \mathrm{c}^{-/-}, \quad \mathrm{JAK} 3^{-/-}, \\
\mathrm{IL}-7 \mathrm{R} \alpha^{-/-}, \\
\mathrm{CD} 45^{-/-}, \\
\mathrm{CD} 3 \delta / \mathrm{CD} 3 \varepsilon^{-/-}\end{array}$ & Reduzido & $\begin{array}{l}\text { Normal ou } \\
\text { incrementado }\end{array}$ & Reduzido & $\begin{array}{l}\text { Marcada diminuição de } \\
\text { células NK }\end{array}$ & $\begin{array}{l}\text { Todos A. R., } \\
\text { exceito } \gamma \mathrm{c}^{-/-} \\
(\mathrm{X}-\mathrm{L})\end{array}$ \\
\hline $\begin{array}{l}\mathbf{T}^{-/-} \mathbf{B}^{-/-} \text {SCID } \\
\mathrm{RAG}^{1 / 2^{-/-},} \\
\text {Ártemis }^{-/-}, \\
\mathrm{ADA}^{-/-}, \\
\text {disgenesis } \\
\text { reticular. }\end{array}$ & $\begin{array}{l}\text { Marcada } \\
\text { diminuição }\end{array}$ & $\begin{array}{l}\text { Marcada } \\
\text { diminuição }\end{array}$ & Reduzido & $\begin{array}{l}\text { Defeito na recombinação } \\
\text { VDJ }\end{array}$ & A. R. \\
\hline $\begin{array}{l}\text { Síndrome de } \\
\text { Omenn }\end{array}$ & Presente & $\begin{array}{ll}\text { Normal ou } \\
\text { diminuído }\end{array}$ & $\begin{array}{l}\text { Reduzido, } \\
\text { exceto IgE }\end{array}$ & $\begin{array}{l}\text { Eritroderma, eosinofília, } \\
\text { adenopatia, } \\
\text { hepatoslenomegalia. }\end{array}$ & A. R. \\
\hline DNA ligase IV & Reduzido & Reduzido & Reduzido & $\begin{array}{l}\text { Microcefalia, distrofia } \\
\text { facial e sensibilidade à } \\
\text { radiação. }\end{array}$ & A. R. \\
\hline $\mathrm{CD} 40 \mathrm{~L}^{-/-}$ & Normal & $\begin{array}{l}\text { Ausência de } \\
\text { IgA, IgG e } \\
\text { IgE. }\end{array}$ & $\begin{array}{l}\text { IgM e } \mathrm{IgD} \\
\text { presente em } \\
\text { concentrações } \\
\text { normais }\end{array}$ & $\begin{array}{l}\text { Neutropenia, } \\
\text { trombocitopenia, anemia } \\
\text { hemolítica. }\end{array}$ & A. R. \\
\hline $\mathbf{P N P}^{-/-}$ & $\begin{array}{l}\text { Diminuição } \\
\text { progressiva }\end{array}$ & Normal & $\begin{array}{l}\text { Ligeira } \\
\text { diminuição }\end{array}$ & \begin{tabular}{|lr} 
Anemia & hemolítica \\
autoimune, & danos \\
neurológicos. & \\
\end{tabular} & A. R. \\
\hline MHC-/- & \begin{tabular}{|l|}
\multicolumn{2}{|l|}{ Diminuição } \\
só de \\
linfócitos \\
$\mathrm{CD}^{+}$
\end{tabular} & Normal & Normal & & A. R. \\
\hline CD3 $\gamma^{-1-}$ & \begin{tabular}{|l|} 
Reduzida \\
expressão de \\
TCR
\end{tabular} & Normal & Normal & & A. R. \\
\hline $\begin{array}{l}\mathrm{CD8}^{+/+}, \text {ZAP- } \\
\text { 70 }^{-/-}, \text {TAP }_{1 / 2}^{-/-}\end{array}$ & $\begin{array}{l}\text { Diminuição } \\
\text { de linfócitos } \\
\text { CD8 } 8^{+}, \\
\text {expressão } \\
\text { normal de } \\
\text { linfócitos } \\
\text { CD4 }^{+}\end{array}$ & Normal & Normal & & A. R. \\
\hline
\end{tabular}

SCID: imunodeficiência combinada grave, A.R.: herança autossômica recessiva, X-L: deficiência ligada ao cromossomo X, JAK: janus-associated kinase, IL-7R: receptor IL-7, ZAP-70: zeta associada à proteína de 70kDa, TAP: transporter associated with antigen processing. 
Tabela 3. Deficiências de imunoglobulinas (NOTORANGELO et al., 2005)

\begin{tabular}{|c|c|c|c|c|}
\hline Doença & \begin{tabular}{|l|} 
Número de \\
linfocitos B
\end{tabular} & Ig sérica & $\begin{array}{l}\text { Característica } \\
\text { associados }\end{array}$ & Herança \\
\hline $\begin{array}{l}\text { Ausência de linfócitos } \mathrm{B}, \\
\text { redução de todas as Ig } \\
\text { séricas: Btk } \\
\text { pesada } \mu^{-/-}, \text {cadeia } \\
\text {, thymona } \alpha^{-/-}, \mathrm{BLNK}^{-/-}\end{array}$ & $\begin{array}{l}\text { Forte redução } \\
\text { ou ausência }\end{array}$ & $\begin{array}{l}\text { Redução de todos } \\
\text { os isótipos. }\end{array}$ & $\begin{array}{l}\text { Infecções graves } \\
\text { causadas por bactérias }\end{array}$ & $\begin{array}{l}\text { Todas A. R., } \\
\text { exceto Btk } \\
(\mathrm{X}-\mathrm{L})\end{array}$ \\
\hline $\begin{array}{l}\text { Redução de ao menos } 2 \\
\text { isótipos de Ig com baixo } \\
\text { número de linfócitos B: } \\
\text { ICOS }^{-/-}, \mathrm{CD}^{-/-} 9^{- \text {TACI }^{--}} \\
\text {BAFF receptor }^{-/-}\end{array}$ & $\begin{array}{l}\text { Normal ou } \\
\text { reduzido }\end{array}$ & $\begin{array}{l}\text { Redução de IgG e } \\
\text { IgA e } \\
\text { concentrações } \\
\text { normais de IgM }\end{array}$ & $\begin{array}{l}\text { Pode ter doenças } \\
\text { autoimunes, ou doenças } \\
\text { linfoproliferativas. }\end{array}$ & $\begin{array}{l}\text { Todas A. R., } \\
\text { exceto TACI } \\
\text { que pode ter } \\
\text { A.R. e A.D. }\end{array}$ \\
\hline $\begin{array}{l}\text { Redução de IgG e IgA } \\
\text { sérica e incremento de } \\
\text { IgM com quantidades } \\
\text { normais de linfócitos B: } \\
\mathrm{AID}^{-/}, \mathrm{UNG}^{-/-} \text {. }\end{array}$ & Normal & $\begin{array}{l}\text { Redução de IgG e } \\
\text { IgA e incremento } \\
\text { de IgM }\end{array}$ & $\begin{array}{l}\text { Aumento dos linfonodos } \\
\text { e do centro germinativo }\end{array}$ & A.R. \\
\hline 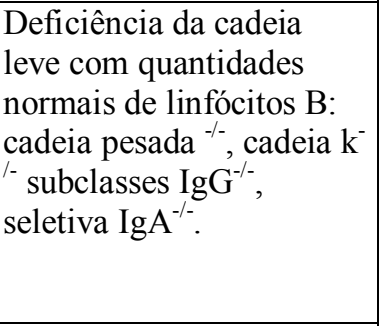 & Normal & $\begin{array}{l}\text { Redução de uma } \\
\text { o mais subclasses } \\
\text { de IgG, IgA e IgE }\end{array}$ & $\begin{array}{l}\text { Pode ser assintomático } \\
\text { ou ter infecções } \\
\text { recorrentes com ou sem } \\
\text { resposta de } \\
\text { imunoglobulinas a } \\
\text { carbohidratos } \\
\text { (antígenos), alergias ou } \\
\text { doenças autoimunes }\end{array}$ & Variável. \\
\hline $\begin{array}{l}\text { Deficiência de anticorpos } \\
\text { específicos com } \\
\text { concentrações normais de } \\
\text { Ig e de linfócitos B }\end{array}$ & Normal & Normal & $\begin{array}{l}\text { Inabilidade da síntese de } \\
\text { anticorpos específicos }\end{array}$ & Variável \\
\hline
\end{tabular}

A.R.: herança autossômica recessiva, A.D.: herança autossômica dominante, X-L: deficiência ligada ao cromossomo X, BLNK: B-cell linker protein, ICOS: induzível coestimulador, TACI: ativador de transmembrana modulador de $\mathrm{Ca}^{+2}$, BAFF: fator de ativação o linfócito $\mathrm{B}$, AID: ativação que induz uma citidina deminase, UNG: uracil DNA glicoilase. 
Tabela 4. Outras imunodeficiências (NOTORANGELO et al., 2005)

\begin{tabular}{|c|c|c|c|c|c|}
\hline Doença & \begin{tabular}{|l}
$\begin{array}{l}\text { Linfócito } \\
\text { circulante }\end{array}$ \\
$T$
\end{tabular} & $\begin{array}{l}\text { Linfócito } \\
\text { circulante }\end{array}$ & Ig sérica & $\begin{array}{l}\text { Características } \\
\text { associadas }\end{array}$ & Herança \\
\hline $\begin{array}{l}\text { Síndrome de Wiskott- } \\
\text { Aldrich }\end{array}$ & $\begin{array}{l}\text { Redução } \\
\text { progressiva }\end{array}$ & Normal & $\begin{array}{l}\text { Redução de } \\
\text { IgM, } \\
\text { aumento de } \\
\text { IgA e IgE }\end{array}$ & $\begin{array}{l}\text { Trombocitopenia, } \\
\text { eczemas, linfomas, } \\
\text { infeções } \\
\text { bacterianas. }\end{array}$ & X-L \\
\hline $\begin{array}{l}\text { Dano no reparo do } \\
\text { DNA: telangiectasia, } \\
\text { síndrome like-ataxia, } \\
\text { síndrome de Nijmegen } \\
\text { breakage, síndrome de } \\
\text { Bloom }\end{array}$ & Reduzido & Normal & $\begin{array}{l}\text { Redução de } \\
\text { IgA, IgE e } \\
\text { das } \\
\text { subclasses de } \\
\text { IgG, } \\
\text { incremento } \\
\text { de IgM }\end{array}$ & $\begin{array}{l}\text { Ataxia, } \\
\text { sensibilidade aos } \\
\text { raios X e a outras } \\
\text { radiações. }\end{array}$ & A. R. \\
\hline $\begin{array}{l}\text { Defeitos tímicos, } \\
\text { síndrome de Di George }\end{array}$ & $\begin{array}{l}\text { Reduzido ou } \\
\text { normal }\end{array}$ & Normal & $\begin{array}{l}\text { Reduzido ou } \\
\text { normal }\end{array}$ & \begin{tabular}{lr}
\multicolumn{3}{l}{ Hipoparatiroidismo, } \\
malformação \\
conotruncal, \\
defeitos em $r \%$ \\
dos rones \\
envolvidos r na \\
maturação do timo.
\end{tabular} & A. D. \\
\hline $\begin{array}{l}\text { Dislasia Imuno ósea } \\
\text { hipoplasia } \\
\text { cartilagem, síndrome } \\
\text { Schimke. }\end{array}$ & Reduzido & Normal & Normal & & A. R. \\
\hline $\begin{array}{ll}\text { Síndrome } & \text { de } \\
\text { Hermansky-Pudlak } & \\
\text { tipo2 } & \end{array}$ & Normal & Normal & Normal & $\begin{array}{l}\text { Albinismo } \\
\text { oculocutâneo, } \\
\text { neutropenia, defeito } \\
\text { na toxicidade do } \\
\text { linfócito T e de } N K .\end{array}$ & A. R. \\
\hline Síndrome de Hiper IgE & Normal & Normal & $\begin{array}{l}\text { Normal ou } \\
\text { elevado IgE }\end{array}$ & $\begin{array}{l}\text { Candidíase } \\
\text { fosas } \\
\text { assimetria } \\
\text { nasais, } \\
\text { facial, } \\
\text { escoliose. }\end{array}$ & A. R. \\
\hline $\begin{array}{l}\text { Candidíase } \\
\text { mucocutânea }\end{array}$ & Normal & Normal & Normal & $\begin{array}{l}\text { Candidíase } \\
\text { mucocutânea, } \\
\text { sensibilidade à } \\
\text { Candida albicans. }\end{array}$ & $\begin{array}{l}\text { A. R. e } \\
\text { A. D. }\end{array}$ \\
\hline
\end{tabular}

SCID: imunodeficiência combinada grave, A.R.: herança autossômica recessiva, X-L: deficiência ligada ao cromossomo X, JAK: janus-associated kinase, IL-7R: receptor IL-7, ZAP-70: zeta associada à proteína de $70 \mathrm{kDa}$, TAP: transporter associated with antigen processing. 


\subsubsection{DEFICIÊNCIAS DAS PROTEÍNAS DE COMPLEMENTO}

Indivíduos deficientes de proteínas do sistema complemento geralmente apresentam uma forte tendência para adquirir infecções piogênicas ocasionadas por bactérias encapsuladas como Neisseria sp., Streptococcus sp. e H. influenzae. Cabe mencionar que indivíduos deficientes de alguma das proteínas da via terminal comum são bastantes suscetíveis a infecções ocasionadas por bactérias do gênero Neisseria. A ocorrência de infecções causadas por este tipo de bactéria em indivíduos deficientes de complemento é mostrado na Tabela 5. A deficiência de alguma destas proteínas ocasiona falha na opsonização, fagocitose e formação do MAC (MORGAN \& WALPORT, 1991; FIGUEROA \& DENSEN, 1991). A Tabela 6 mostra o tipo de herança, a caraterística e as doenças associadas às deficiências complemento.

Tabela 5. Comparação da freqüência de ocorrência de infecções causadas por Neisseria sp., S. pneumoniae e $H$. influenzae em pacientes deficientes de complemento (FIGUEROA \& DENSEN, 1991)

\begin{tabular}{|l|l|l|l|l|}
\hline \multirow{2}{*}{$\begin{array}{l}\text { Deficientes } \\
\left(N^{\circ} \text { de Homozigotos) }\right.\end{array}$} & \multicolumn{3}{|c|}{$\mathbf{N}^{\circ}$ de Pacientes (\%) com } & \multirow{2}{*}{} \\
\cline { 2 - 5 } & Neisseria. sp. & S. pneumoniae & H. influenzae & Total (\%) \\
\hline C1, C4, C2 (161) & $9(5,6)$ & $20(12,4)$ & $8(5)$ & $32(20)$ \\
\hline C3, fI, fH (46) & $17(37)$ & $12(26)$ & $2(4,4)$ & $25(54)$ \\
\hline$P, f D(57)$ & $25(44)$ & $2(3,5)$ & $2(3,5)$ & $29(51)$ \\
\hline $\begin{array}{l}C 5, C 6, C 7, \quad C 8, \quad C 9 \\
(267)\end{array}$ & $151(57)$ & $2(0,8)$ & $0(0)$ & $150(56)$ \\
\hline Total (531) & $\mathbf{2 0 2 ( 3 8 )}$ & $\mathbf{3 6 ( 6 , 8 )}$ & $\mathbf{1 2}(\mathbf{2 , 3})$ & $\mathbf{2 3 6 ( 4 4 )}$ \\
\hline
\end{tabular}

a total de pacientes com infecção causada por algum destes três tipos de organismos encapsulados. Cada paciente foi contado só uma vez. 
Tabela 6. Deficiências de proteínas do sistema complemento (MORGAN \& WALPORT, 1991; WEN et al., 2004; NOTARANGELO et al., 2005; REIS et al., 2006)

\begin{tabular}{|c|c|c|c|c|}
\hline & $\begin{array}{l}N^{\circ} \\
\text { casos }\end{array}$ & Herança & Característica & Doença associada \\
\hline C1q, & 42 & \multirow{4}{*}{ A. R. } & \multirow{4}{*}{$\begin{array}{l}\text { Ativação defeituosa da Via Clássica, } \\
\text { falhas na dissolucão de complexos } \\
\text { imunes e na remoção de células } \\
\text { apoptóticas }\left(\mathrm{Clq}^{-/-}\right) . \\
\end{array}$} & \multirow{4}{*}{$\begin{array}{l}\text { LES, infecções } \\
\text { piogênicas e } \\
\text { glomerulonefrite }\end{array}$} \\
\hline $\mathrm{C} 1 \mathrm{r} / \mathrm{C} 1 \mathrm{~s}$ & 15 & & & \\
\hline $\mathrm{C} 2$ & $>100$ & & & \\
\hline $\mathrm{C} 4$ & 24 & & & \\
\hline $\mathrm{C} 1-\mathrm{INH}$ & $>100$ & A. D. & $\begin{array}{l}\text { Ativação contínua da Via Clássica } \\
\text { e das Lectinas com consumo de } \\
\text { C4/C2. O contato do sistema de } \\
\text { complemento com o sistema de } \\
\text { coagulação resulta na geração de } \\
\text { bradicinina. }\end{array}$ & $\begin{array}{l}\text { Angioedema } \\
\text { hereditário e LES }\end{array}$ \\
\hline MBL & $>30$ & $\begin{array}{l}\text { A. R. e } \\
\text { L-X }\end{array}$ & $\begin{array}{l}\text { Defeito no reconhecimento de } \\
\text { manose com conseqüente defeito } \\
\text { na ativação da Via das Lectinas }\end{array}$ & $\begin{array}{l}\text { Defeito na } \\
\text { opsonização por } \\
\text { fungos }\end{array}$ \\
\hline MASP-2 & & & $\begin{array}{l}\text { Ausência da atividade hemolítica } \\
\text { mediada pela Via das Lectinas }\end{array}$ & $\begin{array}{l}\text { LES e infecções } \\
\text { piogênicas }\end{array}$ \\
\hline Fator D & 1 & A. R. & $\begin{array}{l}\text { Ativação defeituosa da Via } \\
\text { Alternativa }\end{array}$ & $\begin{array}{l}\text { Infecções piogênicas } \\
\text { e por Neisseria sp. }\end{array}$ \\
\hline $\mathrm{C} 3$ & 27 & A. R. & $\begin{array}{l}\text { Ativação defeituosa das três vias de } \\
\text { ativação, ausência do MAC, falha } \\
\text { na opsonização e fagocitose. }\end{array}$ & $\begin{array}{l}\text { Infecções piogênicas } \\
\text { e glomerulonefrite }\end{array}$ \\
\hline $\mathrm{C5}$ & 38 & \multirow[t]{5}{*}{ A. R. } & \multirow{5}{*}{$\begin{array}{l}\text { Formação defeituosa do MAC, } \\
\text { ausência da atividade hemolítica } \\
\text { mediada por qualquer uma das três } \\
\text { vias. }\end{array}$} & \multirow{5}{*}{$\begin{array}{l}\text { Infecção por } \\
\text { Neisseria } s p\end{array}$} \\
\hline C6 & $>50$ & & & \\
\hline $\mathrm{C} 7$ & 26 & & & \\
\hline $\mathrm{C} 8$ & 32 & & & \\
\hline C9 & $>50$ & & & \\
\hline Properdina & $>50$ & $\mathrm{~L}-\mathrm{X}$ & $\begin{array}{l}\text { Falha na ativação da Via } \\
\text { Alternativa }\end{array}$ & $\begin{array}{l}\text { Infecções piogênicas } \\
\text { e por Neisseria sp. }\end{array}$ \\
\hline Fator I & 31 & A. R. & $\begin{array}{l}\text { Ativação descontrolada da Via } \\
\text { Alternativa com consumo de C3, } \\
\text { aumento na formação da C3- e C5- } \\
\text { convertases das Vias Clássica e } \\
\text { Alternativa. }\end{array}$ & $\begin{array}{l}\text { LES, infecções } \\
\text { piogênicas e } \\
\text { glomerulonefrite }\end{array}$ \\
\hline Fator $\mathrm{H}$ & 21 & A. R. & $\begin{array}{l}\text { Espontânea ativação da via } \\
\text { alternativa com consumo de C3. }\end{array}$ & $\begin{array}{l}\text { LES, infecções } \\
\text { piogênicas, } \\
\text { glomerulonefrite e } \\
\text { SHU. }\end{array}$ \\
\hline
\end{tabular}

A. R.: autossômica recesiva, A. D.: autossômica dominante, L-X: herança ligada ao cromossomo X, LES: lúpus eritematoso sistêmico, SHU: síndrome hemolítico-urêmica 


\subsubsection{DEFICIÊNCIAS DE PROTEÍNAS DA VIA CLÁSSICA}

As defic iências de proteínas da via clássica de complemento (C1q, C1r, C1s, C2 e C4) estão associadas a maior suscetibilidade a infecções graves e desenvolvimento de doenças autoimunes como lúpus eritematoso sistêmico (LES). A incidência de indivíduos deficientes das proteínas C1q, C2 ou C4 e que sofrem de LES é de $90 \%, \sim 15 \%$ e 75\%, respectivamente (PICKERING et al., 2000). Estas proteínas estão envolvidas com eliminação de imunocomplexos, de produtos liberados por células apoptóticas que podem funcionar como auto-antígenos (ver em Solubilização e Transporte de Imunocomplexos e Remoção dos Imunocomplexos pelo Fígado). A eliminação de linfócitos B imaturos durante a vida embrionária é dependente de C1q e C4, mas não de C3. (PRODEUS et al., 1998).

A deficiência de C1q é causada pela falha na síntese de C1q (60\% dos casos) ou pela síntese de C1q não funcional (40\% dos casos). C1q, C1r e C1s são requeridos para formar o complexo $\mathrm{C} 1$. A deficiência de algum destes três componentes inibe a formação do complexo C1. Em geral, indivíduos que apresentam a deficiência de $\mathrm{C} 1 \mathrm{~s}$, também apresentam a deficiência de C1r. Uma das explicações poderia ser a proximidade dos genes C1s e C1r no cromossomo 12 localização 12p13. Indivíduos deficientes destas proteínas podem apresentar pneumonias, tuberculose pulmonar, infecções por Staphylococcus, rash, vasculites, glomerulonefrite, hematúria ou ainda serem assintomáticos. Na literatura apresentam-se três estudos moleculares que explicam a deficiência de C1r e C1s. INOUE et al. (1998) estudaram um caso de um homem japonês de 26 anos com deficiência total de C1s e deficiência parcial de C1r, com deleção de 4 pb (TTTG) no éxon 10 do gene C1s. ENDO et al. (1999) encontraram no alelo paterno de um menino japonês uma deleção de 4 pb (TTTG) no éxon 10 do gene C1s e no alelo materno uma substituição de uma G por uma $\mathrm{T}$ no éxon 12 do gene C1s. DRAGON-DUREY et al. (2001) encontraram em uma menina caucasiana uma substituição de uma $\mathbf{C}^{534}$ por uma $\mathbf{T}$ no éxon 12 do gene C1s. As mutações apresentadas 
nestes três casos geram códons de parada prematura, que ocasionam o bloqueio da tradução da proteína $\mathrm{C} 1 \mathrm{~s}$.

Em nosso laboratório, AMANO (2006) em seu trabalho de mestrado, descreveu a deficiência total de $\mathrm{C} 1 \mathrm{~s}$ e parcial de $\mathrm{C} 1 \mathrm{r}$ em quatro irmãos, pertencentes a uma família brasileira com história de consangüinidade. Destes quatro irmãos, dois são assintomáticos, enquanto que os outros dois sofrem de LES. Estes pacientes apresentam uma substituição de uma $\mathbf{C}^{\mathbf{9 3 8}} \mathbf{G}$ o que gera um códon de parada prematura. O seqüenciamento do cDNA de C1r não apontou a presença de alguma mutação que pudesse ser a causa da deficiência. Sugerindo assim que a regulação de $\mathrm{C} 1 \mathrm{r}$ pode ser possivelmente dependente da presença de $\mathrm{C} 1 \mathrm{~s}$.

Os dois isotipos de C4 (C4A e C4B) são codificados por genes altamente polimórficos situados na região da classe II do $\mathrm{MHC}$ no cromossomo 6. Tanto $\mathrm{C} 4 \mathrm{~A}$ como $\mathrm{C} 4 \mathrm{~B}$, estão presentes em igual concentração em $75 \%$ da população mundial. Uma pequena diferença entre os aminoácidos de cada isótipo afeta a sua capacidade de ligar-se a outras proteínas (C4A) ou de se ligar a resíduos de carboidratos em diversas superfícies celulares (C4B) (WAN et al., 2004). A deficiência completa de C4 requer a herança de alelos defeituosos nos 4 loci. A deficiência heterozigota de C4 é mais freqüente, estima-se que apenas $60 \%$ da população possua os 4 genes funcionais (MORGAN \& WALPORT, 1991).

O angioedema hereditário (HAE) é uma doença caracterizada por edema nas mucosas com duração de aproximadamente dois a três dias, com ausência de febre ou de outras manifestações clínicas. Clinicamente, encontram-se três formas de HAE: o tipo I é caracterizado por uma redução de $30 \%$ ou menos na concentração de C1-INH sérica. No HAE tipo II os indivíduos secretam uma proteína C1-INH disfuncional. No tipo III o padrão de heramça genética é dominante, mas ligado ao cromossomo X (BORK et al., 2000). 


\subsubsection{DEFICIÊNCIAS DAS PROTEÍNAS DA VIA DAS LECTINAS}

A deficiência de MBL é uma das mais freqüentes (5,3\% da população da Finlândia), onde uma grande proporção é assintomática (AITTONIEMI et al., 1996). Um estudo feito com 9 crianças deficientes de MBL demonstrou que esta deficiência não se encontra isolada, mas sim associada a outros tipos de imunodeficiências humorais. AITTONIEMI et al. (1998) observaram que crianças com esta deficiência também possuem deficiência parcial ou total de uns dos alótipos da imunoglobulina $\operatorname{IgG}\left(\operatorname{IgG}_{2}, \mathrm{IgG}_{3}\right.$ ou $\left.\mathrm{IgG}_{4}\right)$ e a associação destes dois tipos de deficiência causam falha na opsonização de bactérias. SUPER et. al. (1989) num ensaio in vitro observaram que o soro deficiente de MBL apresenta falha na opsonização de leveduras (S. cerevisiae). Esta opsonização é corrigida mediante a adição de MBL purificada (dose dependente). Estes autores também observaram uma correlação entre a concentração de MBL plasmática e a formação de $\mathrm{C} 3 \mathrm{~b}$ em indivíduos saudáveis. O mesmo grupo de pesquisa encabeçado por SUMIYA et al. (2003) observou a falha na opsonização destes soros deficiêntes deve-se à substituição de uma $\mathrm{GG}^{\mathbf{2 3 0}} \mathrm{C}$ por uma $\mathrm{GA}^{\mathbf{2 3 0}} \mathrm{C}$ no éxon 1 do gene $M B L$. Esta troca produz a troca de glicina por ácido aspártico modificando a conformação tridimensional da MBL e facilitando com isso sua posterior degradação. Em estudo feito com crianças inglesas, encontrou-se que as crianças que apresentam mutações heterozigotas no códon 52, códon 54 e códon 57 do gene $M B L$ sofriam com maior freqüência de osteomielites, otite média, infecções por Streptococcos, infecção no trato urinário, gastroenterites, celulites e abscessos, febre de origem desconhecida, tonsilites, meningococemia e infecções no trato respiratório. Entretanto, as crianças que apresentam mutações homozigotas no códon 54 e 57 do gene $M B L$ apresentam maior risco de contrair infecções meningocócicas graves e inclusive septicemia generalizada (SUMMERFIELD et al., 1997). 


\subsubsection{DEFICIÊNCIAS DAS PROTEÍNAS DA VIA ALTERNATIVA}

A properdina estabiliza a C3- e C5-convertase e sua deficiência está associada ao

cromossomo X, portanto é descrita apenas em indivíduos do sexo masculino. Três tipos de deficiência de properdina têm sido descritos. No primeiro tipo não se detecta a presença de properdina, no segundo a properdina está ativa em apenas $10 \%$ dos níveis normais e no último tipo há produção de properdina não funcional. Estes pacientes apresentam infecções causadas por bactérias do gênero Neisseria (MORGAN \& WALPORT, 1991).

HIEMSTRA et al. (1989) descreveram o primeiro caso da deficiência completa de Fator D em homem caucasiano. Este paciente sofreu três episódios infecciosos, onde primeiro foi de meningite e os outros dois de septicemia generalizada, ocasionadas por Neisseria. Neste paciente a opsonização e a fagocitose foram restauradas mediante adição de Fator D ao soro.

BIESMA et al. (2001) descreveram a deficiência de Fator D numa família dinamarquesa com história de consangüinidade, onde uma das netas sofreu de sérias infecções causadas por Neisseria meningitidis. Ao avaliar a atividade hemolítica mediada pelo complemento, observou-se que cinco integrantes desta família (pertencentes a três gerações diferentes) não ativam a via alternativa, por conta de carência do Fator D no soro destes pacientes. Observou-se também que nos soros deficientes de Fator D a opsonização e fagocitoses de E. coli e N. meningitides e fagositose por neutrófilos encontrava-se comprometida, mas foi restaurada ao se adicionar Fator D purificado. Ao estudar as causas moleculares desta deficiência foi encontrada nestes deficiêntes uma subtituição de $\mathrm{TC}^{125} \mathrm{G}$ a $\mathrm{TA}^{125} \mathrm{G}$ no éxon 2 que forma um códon de parada prematura.

FEDERMANN et al. (1980) estudaram a atividade hemolítica de diferentes variantes do Fator B mostrando que a variante BfFO5.5 não ativa a hemólise pela via alternativa. Esta variante foi encontrada em três gerações (6 indivíduos) em associação com o haplótipo HLAA11 mostrando-se inativa em todos os membros desta família. Estes indivíduos possuem além do alelo FO5.5 o alelo Bfs que determina a síntese do Fator B hemolíticamente ativo. A 
concentração de Fator B no soro é normal a moderadamente baixo. Este estudo constitui a primeira descrição de uma anomalia genética de Fator B em humanos. Entretanto, ainda não foi descrita em humanos a deficiência completa de Fator B.

A proteína C3 exerce um papel fundamental nas três vias de ativação do sistema complemento. Os produtos de clivagem desta proteína participam de diversas funções imunológicas como: formação da C3- e C5-convertase, produção de opsoninas, liberação de mediadores inflamatórios, a ativação de linfócitos B com a conseqüente produção de anticorpos, solubilização, remoção de imunocomplexos e, por último, propriedade adjuvante. Em nosso laboratório ULBRICH et al. (2001) mostraram que soro C3 deficiente ativado com LPS, assim como soro humano normal inativado a $56^{\circ} \mathrm{C}$, induzia uma menor migração de leucócitos. Em outra avaliação, constatou-se que a ingestão e morte de C. albicans por fagócitos normais, ao serem opsonizadas por soro do probando, foram semelhantes à ingestão e morte destes fungos quando tratados por soro inativado. Dessa maneira, a incapacidade de exercer as funções imunológicas dependentes do complemento causadas pela ausência de C3 resultaria em maior suscetibilidade a infecções.

Em sua tese de mestrado REIS (2003) mostrou que a deficiência de C3 em dois indivíduos brasileiros, deve-se a algumas mutações no cDNA do gene C3. O cDNA do paciente 1 apresentou uma substituição de $\mathrm{T}^{1001}$ por $\mathrm{C}^{1001}$ no éxon 9 que resulta na troca de uma $\mathrm{L}^{314}$ por uma $\mathrm{P}^{314}$, uma substituição silenciosa de $\mathrm{G}^{972}$ por $\mathrm{A}^{972}$ que no momento a tradução dá origem a uma $\mathrm{R}^{304}$ e por último a substituição de uma $\mathrm{G}^{1716}$ por $\mathrm{A}^{1716}$ no éxon 13 que troca um resíduo de $\mathrm{W}^{552}$ pela formação de um códon de parada prematura no gene C3. O cDNA do paciente 2, estudado anteriormente por ULBRICH et al. (2001) ok apresentou a substituição de $\mathrm{T}^{1001}$ por $\mathrm{C}^{1001}$ no éxon 9 que resulta na substituição polimorfica de uma $\mathrm{L}^{314}$ por uma $\mathrm{P}^{314}$, a substituição silenciosa de $\mathrm{T}^{1791}$ por $\mathrm{C}^{1791}$ no éxon 14 que resultam na formação de uma $\mathrm{P}^{577}$, uma segunda substituição silenciosa de $\mathrm{C}^{2454}$ por $\mathrm{T}^{2454}$ no éxon 19 que resultam 
na formação de uma $S^{798}$ e uma terceira substituição silenciosa de uma $C^{4371}$ por $T^{4371}$ no éxon 35 que resulta na formação de uma $A^{1437}$ e por último a formação de um códon de parada prematura devido a uma substituição $C^{2602}$ por $T^{2602}$ no éxon 20 do gene $C 3$.

VYSE et al. (1994) relataram o caso de 3 famílias deficientes de Fator I onde dois integrantes (irmãos) de uma destas famílias apresentaram esta deficiência. Indivíduos deficientes de Fator I apresentam concentrações reduzidas de C3 no plasma. Estes indivíduos deficientes apresentam numerosos casos de infecções recidivantes causados por bactérias do gênero Neisseria sp.

Nosso grupo de pesquisa (NAKED et al., 2000) descreveu o caso de uma chilena proveniente de uma família com história de consangüinidade que morreu aos 4 anos de idade despoies de ter desenvolvido múltiplas infecções bacterianas (meningite meningocócica, pneumonia, epilepsia de origem bacteriana, otite média e piodermite).Ao avaliar a atividade hemolítica mediada por complemento, encontramos níveis reduzidos da ativação da via clássica (30 \% - valores normais 56 a $192 \%)$ e nulos na via alternativa o que nos sugeriu a deficiência de alguma proteína da via alternativa compartilhada pela via clássica. A deficiência total de Fator I e parcial de Fator H $(151 \mu \mathrm{g} / \mathrm{ml}$ - valores normais 228,51 a 829,17 $\mu \mathrm{g} / \mathrm{ml})$ foi encontrada no soro desta paciente. Isto leva a forte consumo de C3 $(290 \mu \mathrm{g} / \mathrm{ml}-$ valores normais 610 a $1410 \mu \mathrm{g} / \mathrm{ml}$ ) devido à falha na regulação da ativação da alça de amplificação da via alternativa.

Dois anos mais tarde (AMADEI et al., 2001) descrevemos também o caso duas irmãs brasileiras com história de consangüinidade. A irmã mais velha desenvolveu lúpus eritematoso sistêmico na sua infância, além de outras infecções de origem bacteriana. A irmã mais nova desenvolveu uma infecção gastro-intestinal e um grave síndrome de estresse respiratório. Ao avaliar a atividade hemolítica mediada por complemento, encontramos que o soro de ambas as pacientes não tinhan qualquer atividade mediada pela via clássica ou 
alternativa. A concentração de Fator I e Fator B encontraram-se abaixo do límite de normalidade (64 a $13 \mu \mathrm{g} / \mathrm{ml}$ e $183-513 \mu \mathrm{g} / \mathrm{ml}$, respectivamente), a concentração de Fator $\mathrm{H}$ foi de 93 e $105 \mu \mathrm{g} / \mathrm{ml}$, respectivamente - límite de normalidade 454 a $124 \mu \mathrm{g} / \mathrm{ml}$. Semelhante ao estudo feito por NAKED et al. (2000) a falha nestas proteínas reguladoras causam um consumo exagerado de C3 (127 e $259 \mu \mathrm{g} / \mathrm{ml}$, respectivamente) devido à formação descontrolada da C3-convertase.

Em nosso laboratório BARACHO (2002) ao estudar uma família brasileira com história de consangüinidade encontrou que duas irmãs apresentavam deficiência do Fator I. Tanto o seqüenciamento do cDNA do Fator I como o seqüenciamento do gene Fator I revelaram a presença de uma inserção $\mathrm{A}^{1204} \mathrm{~T}^{1205}$ no éxon 11, a qual gera um códon de parada prematura, que explicaria a deficiência desta proteína nas duas irmãs.

\subsubsection{DEFICIÊNCIAS DAS PROTEÍNAS DA VIA TERMINAL COMUM}

Indivíduos deficientes nas proteínas da via terminal comum (C5, C6, C7, C8 e C9), sofrem um bloqueio na formação do MAC. O MAC por ter uma função importante na neutralização de Neisseria, indivíduos deficientes de uma destas proteínas, apresentam predisposição a infecções ocasionadas por meningococos e gonococos (MORGAN \& WALPORT, 1991).

O risco de uma doença por meningococcos em pessoas deficientes das proteínas da via terminal comum (LCCD, do inglês - late complement component deficient individuals) é de 7000 a 10000 vezes mais elevados que em indivíduos normais, e 60\% de indivíduos LCCD há tido pelo menos uma experiência de doença por meningococcos, dos quais aproximadamente 50\% sofreram de uma experiência adicional da doença (Tabela 3) (FIGUEROA \& DENSEN, 1991). 
Tabela 7. Comparação das doenças ocasionadas por meningococos em indivíduos normais, LCCD (complement component deficient individuals) e indivíduos deficientes de properdina (FIGUEROA \& DENSEN, 1991).

\begin{tabular}{|c|c|c|c|c|}
\hline \multirow{2}{*}{\multicolumn{2}{|c|}{ Parâmetros }} & \multicolumn{3}{|c|}{ Indivíduos } \\
\hline & & Normal & $L C C D$ & Properdina $^{-/-}$ \\
\hline \multicolumn{2}{|l|}{$N^{\circ}$ de homozigotos } & & 267 & $54-70$ \\
\hline \multicolumn{2}{|c|}{$\begin{array}{l}N^{\circ} \text { de indivíduos com infecção por } \\
\text { meningococos }\end{array}$} & & 151 & $25-37$ \\
\hline \multicolumn{2}{|c|}{ Freqüência da infecção (\%) } & 0,0072 & 57 & $46-53$ \\
\hline \multicolumn{2}{|c|}{ Proporção homem / mulher } & $1: 3: 1$ & $2: 2: 1$ & $21: 0-37: 1$ \\
\hline \multicolumn{2}{|c|}{ Idade média do primeiro episódio } & 3 & 17 & $14-11,5$ \\
\hline \multicolumn{2}{|l|}{ Recorrência (\%) } & 0,34 & 41 & $2-1,4$ \\
\hline \multicolumn{2}{|l|}{ Recaída (\%) } & 0,6 & 7,6 & 0 \\
\hline \multicolumn{2}{|c|}{ Mortalidade / 100 episódios (\%) } & 19 & 1,5 & $12-51,4$ \\
\hline \multirow{3}{*}{ Sorogrupos infectantes } & $N^{\circ}$ isolados & 3184 & 67 & 16 \\
\hline & $\% B$ & 50 & 19,4 & 18,7 \\
\hline & $\% Y$ & 4,4 & 32,8 & 37,5 \\
\hline
\end{tabular}

A resposta a meningococos em indivíduos LCCD é diferente da resposta encontrada em indivíduos normais devido ao aumento da carga parasitária nos indivíduos LCCD durante a infecção, à falha da formação do MAC sobre a bactéria (Figura 8), à prolongada sobrevivência do meningococos dentro do fagócito, à apresentação de antígenos alterada e à ligação de fragmentos $\mathrm{C} 3 \mathrm{~b} / \mathrm{iC} 3 \mathrm{~b}$ na superfície destes organismos encapsulados que facilita a fagocitose em neutrófilos (FIGUEROA \& DENSEN, 1991) e à falta de quimioataxia por C5a (Ver em Atividade Quimiotática Dependente de C5) (DENSEN, 1989) o que altera a resposta imune contra este patógeno. 

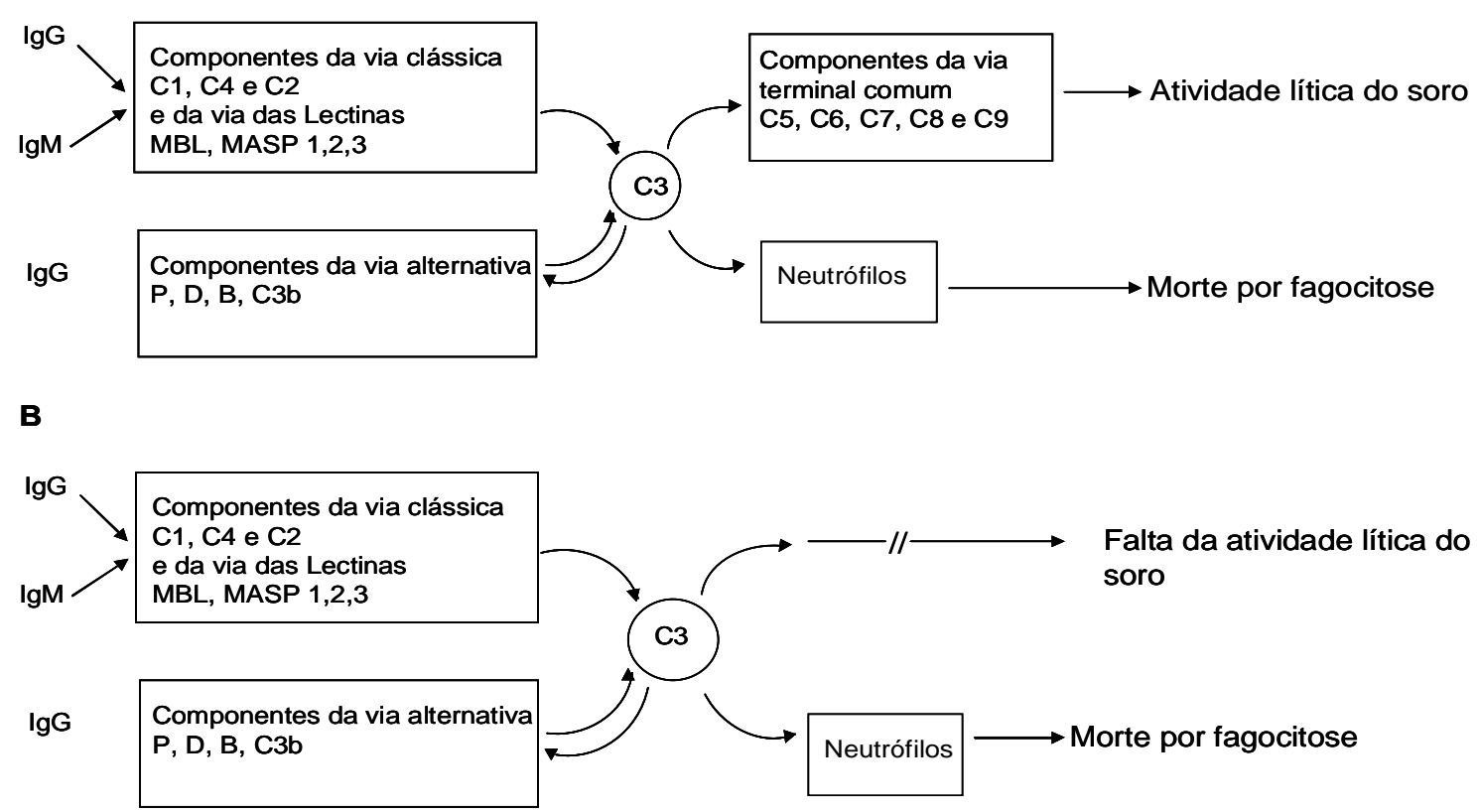

Figura 10. Fatores que contribuem à falha da resposta imune contra meningococos em indivíduos complemento suficiêntes (A) e indivíduos LCCD (B), modificado a partir de FIGUEROA \& DENSEN (1991).

A vacinação com polissacarídeos purificados destas bactérias capsuladas confere uma proteção contra doenças causadas por diversos sorogrupos de meningococos. Anticorpos específicos formados contra estes antígenos em indivíduos normais ativam a opsonização e a fagocitose devido à formação e à deposição do fragmento $\mathrm{C} 3 \mathrm{~b}$ na superfície capsular e subcapsular o que promove juntamente com os anticorpos (IgG2) a remoção da bactéria encapsulada do organismo pelos fagócitos. Em indivíduos LCCD esta resposta é similar com exceção da formação do MAC. FIJEN et al. (2000) mostraram num ensaio in vitro que o alótipo de $\mathrm{IgG}_{2}, \mathrm{C} 3 \mathrm{~b}$ e $\mathrm{CR} 3$ atuam sinergicamente na opsonização e fagocitose da $N$. meningitidis W135, por células polimorfonucleares em indivíduos LCCD. Estudos feitos por POTTER et al. (1990) mostraram que indivíduos LCCD durante uma infecção causada por meningococos produzem 10 vezes mais anticorpos específicos tanto para a membrana externa como para lipopolissacarídeos do que os indivíduos normais. 
A deficiência de C6 é a terçeira deficiência de complemento mais comum entre caucasianos, com uma prevalência de 1: 60000 indivíduos, destes 25\% dos casos, é formado por indivíduos assintomáticos (MORGAN \& WALPORT, 1991). Nas províncias de Western Cape e Gauteng na África do Sul, infecções causadas por meningococos, têm uma incidência de 20-100:100000 indivíduos por ano, onde a maioria de indivíduos afetados é C6 deficiente (POTTER et al., 1990). Um total de 45 casos de indivíduos C6 deficientes que apresentaram infecções ocasionadas por $N$. meningitidis $\mathrm{B}$ foi diagnosticado nesta área (ORREN \& POTTER, 2004).

Apesar do gene C6 se encontrar próximo do gene C7, a deficiência de $C 7$ não é comum entre caucasianos depois da deficiência de C9, a deficiência de C7 é a segunda deficiência de complemento mais comum entre japoneses, com uma incidência de 1: 25000 (INAI et al., 1989).

Já que a proteína $\mathrm{C} 8$, é composta por 3 cadeias $(\alpha, \beta$ e $\gamma)$ e cada uma destas é codificada por genes diferentes, a deficiência de C8 pode ser resultado de falha na síntese de qualquer uma das três cadeias. Nesta proteína a cadeia $\alpha$ e $\gamma$ estão covalentemente ligadas, mas a cadeia $\beta$ não está ligada covalentemente a $\alpha \gamma$. A deficiência da $\mathrm{C} 8 \beta$ tem sido encontrada somente em caucasianos, enquanto a deficiência de C8 $\alpha \gamma$ tem sido encontrada em japoneses e negros (INAI et al., 1989).

A deficiência de C9 é rara em caucasianos, ZOPPI et al. (1990) descreveram pela primeira vez a deficiência de C9 em dois irmãos pertencentes a uma família suíça com numerosos casos de infecções ocasionadas por bactérias do gênero Neisseria, e nestes indivíduos a formação do MAC pode ser reconstituída mediante a adição de C9. Em outro estudo com 145640 japoneses, observou-se que os soros de 139 japoneses (0,095\%) não ativavam nem a via clássica nem a via alternativa, sendo posteriormente demonstrado que estes indivíduos eram deficientes de C9 (FUKUMORI et al., 1989). 


\subsubsection{DEFICIÊNCIA DA PROTEÍNA C5}

A deficiência de C5 (C5D) é muito rara e não pode ser atribuída a uma raça, etnia ou população ou mais prevalente em alguma região em particular. Até o momento, foram relatados 38 casos de pacientes com deficiência completa deste componente do sistema complemento (Tabela 5) distribuídos em 21 famílias.

Os avanços em Biologia Molecular vêm contribuindo para uma melhor identificação da presença de possíveis mutações no gene C5. WANG et al. (1995) investigaram as causas moleculares da deficiência da proteína C5 em 3 famílias. A primeira família já havia sido estudada anteriormente por ROSENFELD et al. (1976), quando encontraram uma primeira mutação $\mathrm{C}^{4521} \mathrm{AG}$ para $\mathrm{T}^{4521} \mathrm{AG}$ no éxon 36. A mutação acima mencionada forma no momento da tradução um códon de parada prematura na cadeia $\alpha$, no lugar da arginina esperada em todos os indivíduos normais. WANG et al. (1995) estudando uma segunda família C5D, caracterizada previamente por PETER et al. (1981) encontraram uma mutação nonsense no éxon 1 de uma $\mathrm{C}^{84} \mathrm{AG}$ para TAG. Esta substituição localizada no códon que codifica o primeiro aminoácido da cadeia $\beta$ no momento da tradução troca uma glicina por um códon de parada prematura. Além disso, este grupo observou que todos os indivíduos estudados apresentavam uma condição heterozigota (deleção de 710 pb localizada no éxon 1, com exceção de uma terceira família que apresentou uma deleção do 1010 pb localizada no éxon 36.

DELGADO-CERVIÑO et al. (2005) encontraram uma deleção e substituição presente no éxon 40 em três irmãos homozigotos, no outro irmão heterozigoto e no pai, membros de uma família de origem espanhola (o triplete CCC na posição 4884-4886 foi trocado por GC) que causa uma modificação no quadro de leitura no momento da transcrição com a conseqüente produção de um códon de parada prematura neste mesmo éxon. 
PFARR et al. (2005) mostraram que o gene C5 de um menino paquistanês apresentava substituição no éxon 10 de uma A por uma $G$ na posição 1115 , o que prediz a substituição de uma Lis por uma Arg no códon 372 no momento da tradução de RNA em proteína. Esta alteração foi encontrada em um dos alelos de todos os membros da família responsável pela diminuição da concentração de C5 no soro destes familiares. No entanto, o indivíduo deficiente apresentou esta alteração nos dois alelos o que anulava a presença de C5 no soro. Quando avaliaram uma região de 540 pb compreendida entre o éxon 9 e éxon 12 de todos os membros da família, observaram que esta região estava ausente no indivíduo C5D. Após seqüenciamento do cDNA de C5 de toda a família, constatou-se um salto no éxon 10 (116 pb), causando uma mudança no quadro de leitura e a criação de um códon de parada prematura, anulando a tradução tanto da cadeia $\alpha$ como da cadeia $\beta$ da proteína $\mathrm{C} 5$ no indivíduo deficiente. O seqüenciamento também provou que a substituição da A pela $G$, localizada no final do éxon 10 dentro de uma região conhecida por exonic splicing enhancer influenciava a exclusão do éxon 10 no momento da tradução. 


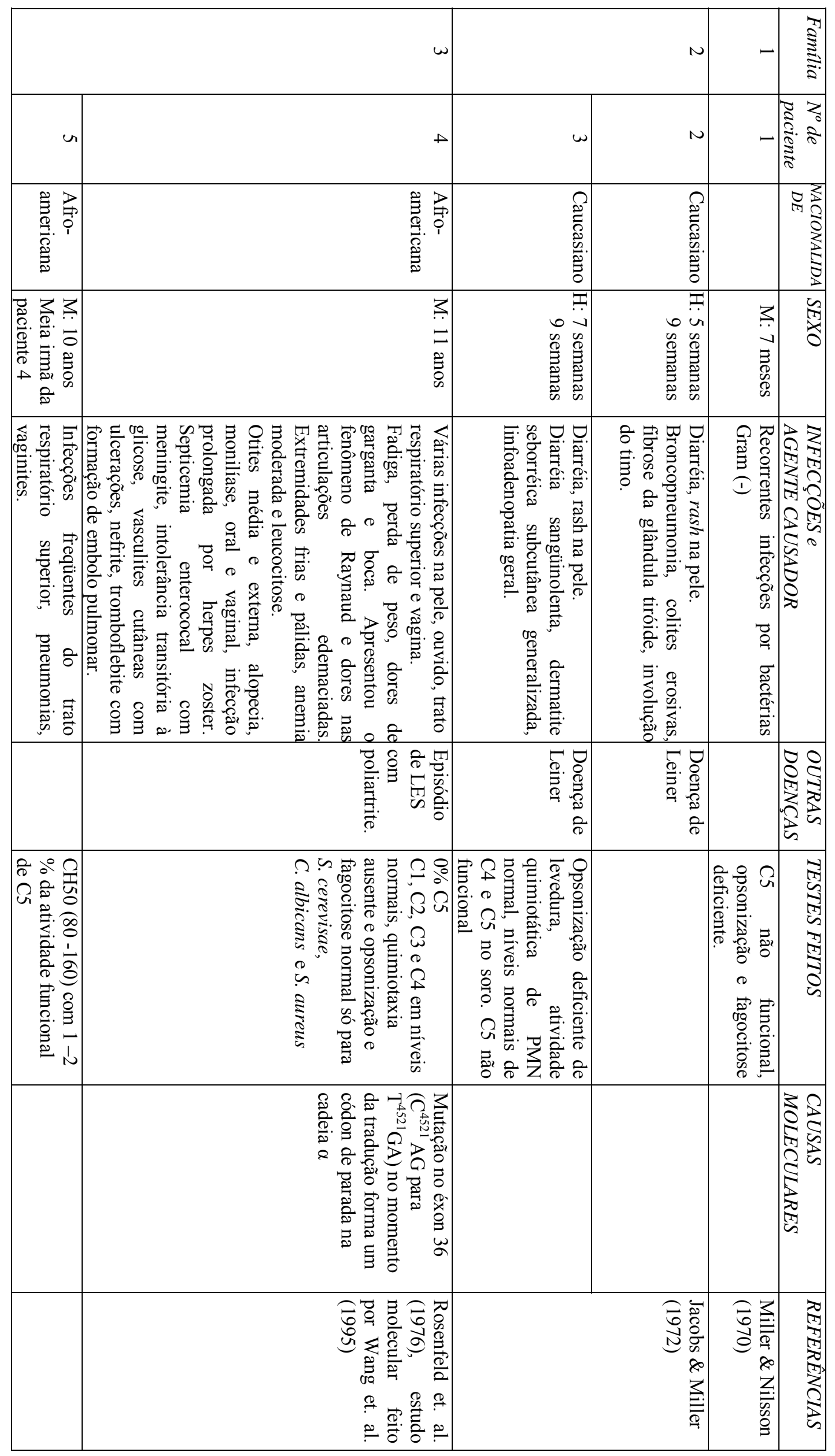




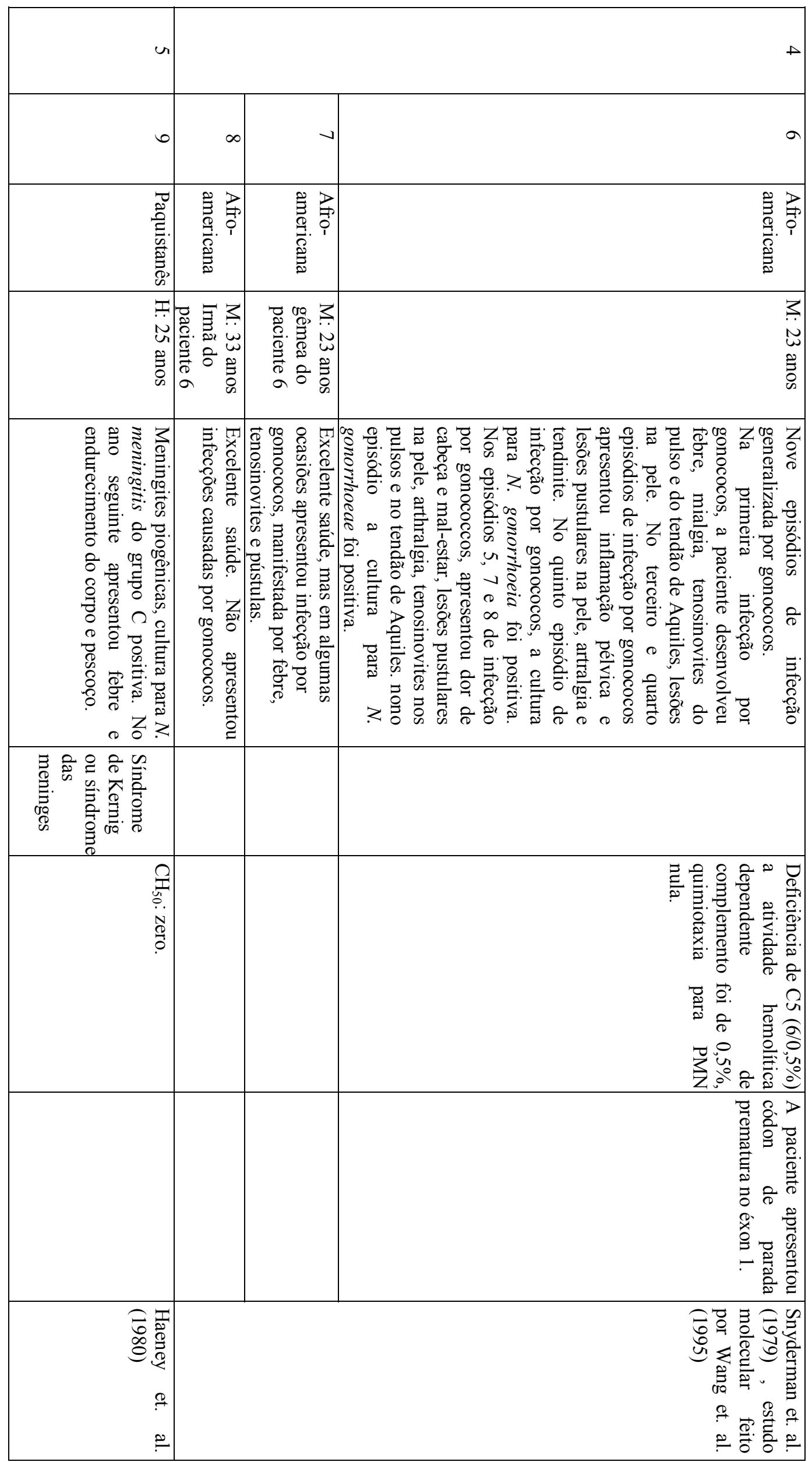




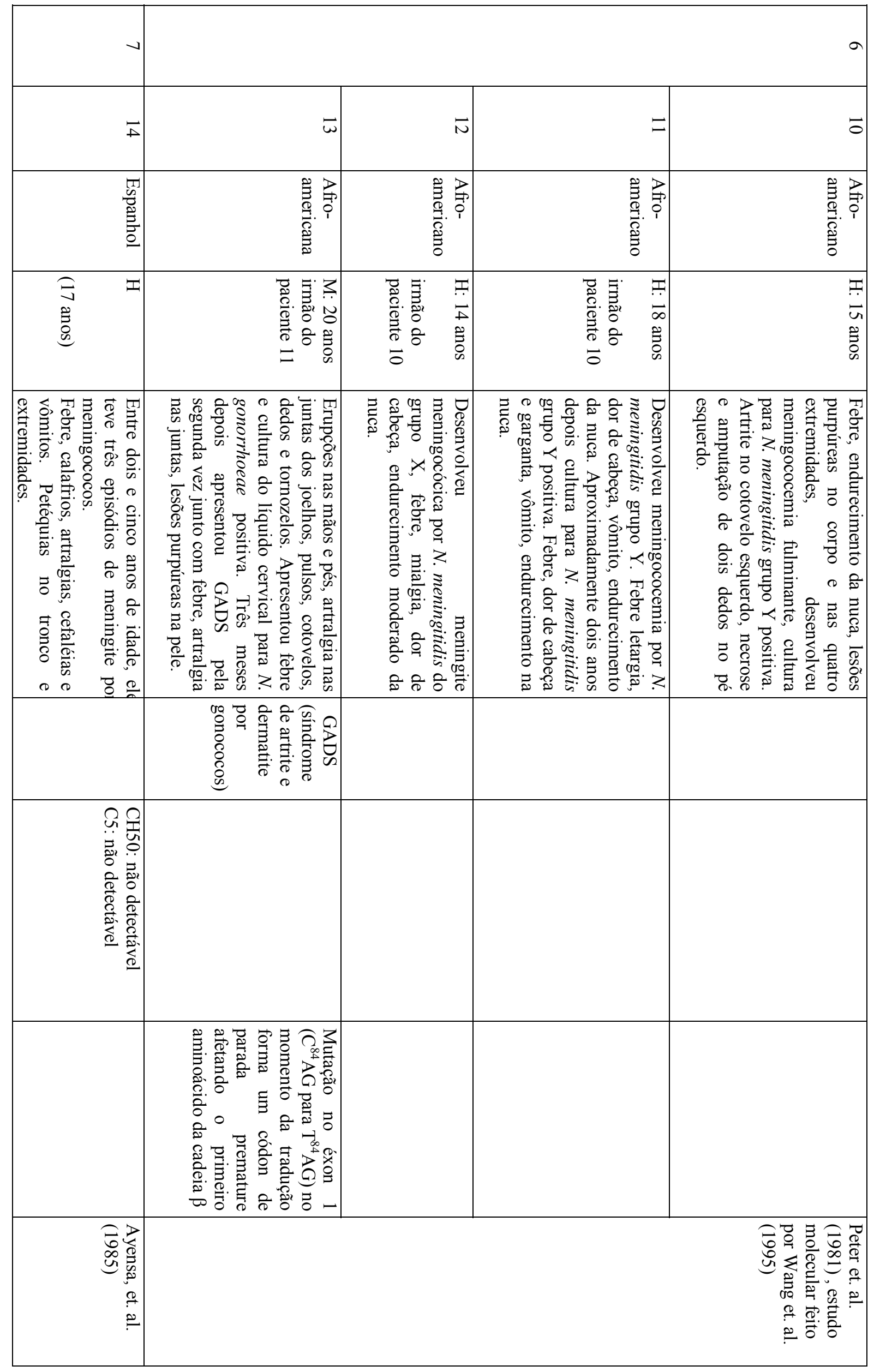




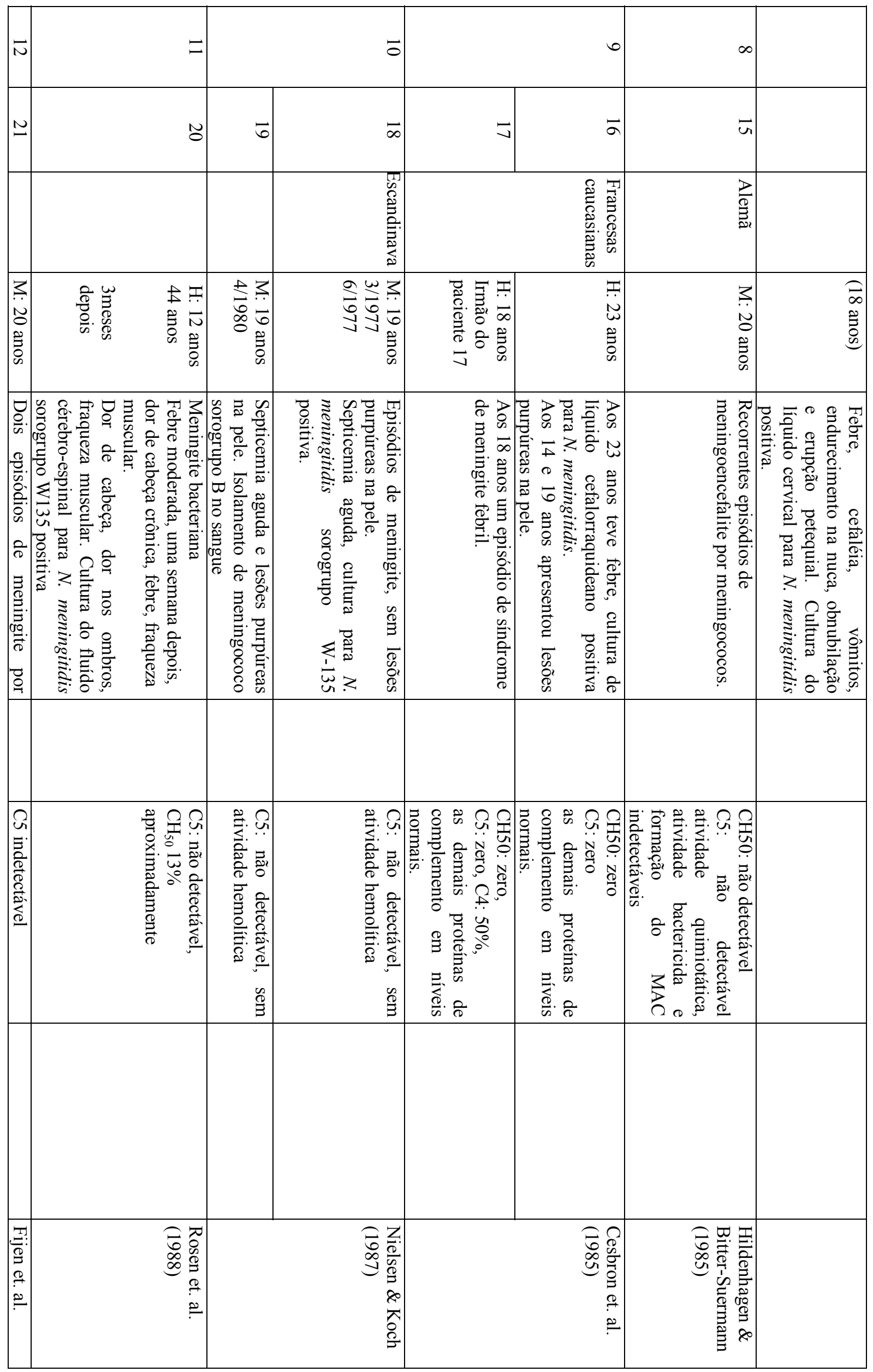




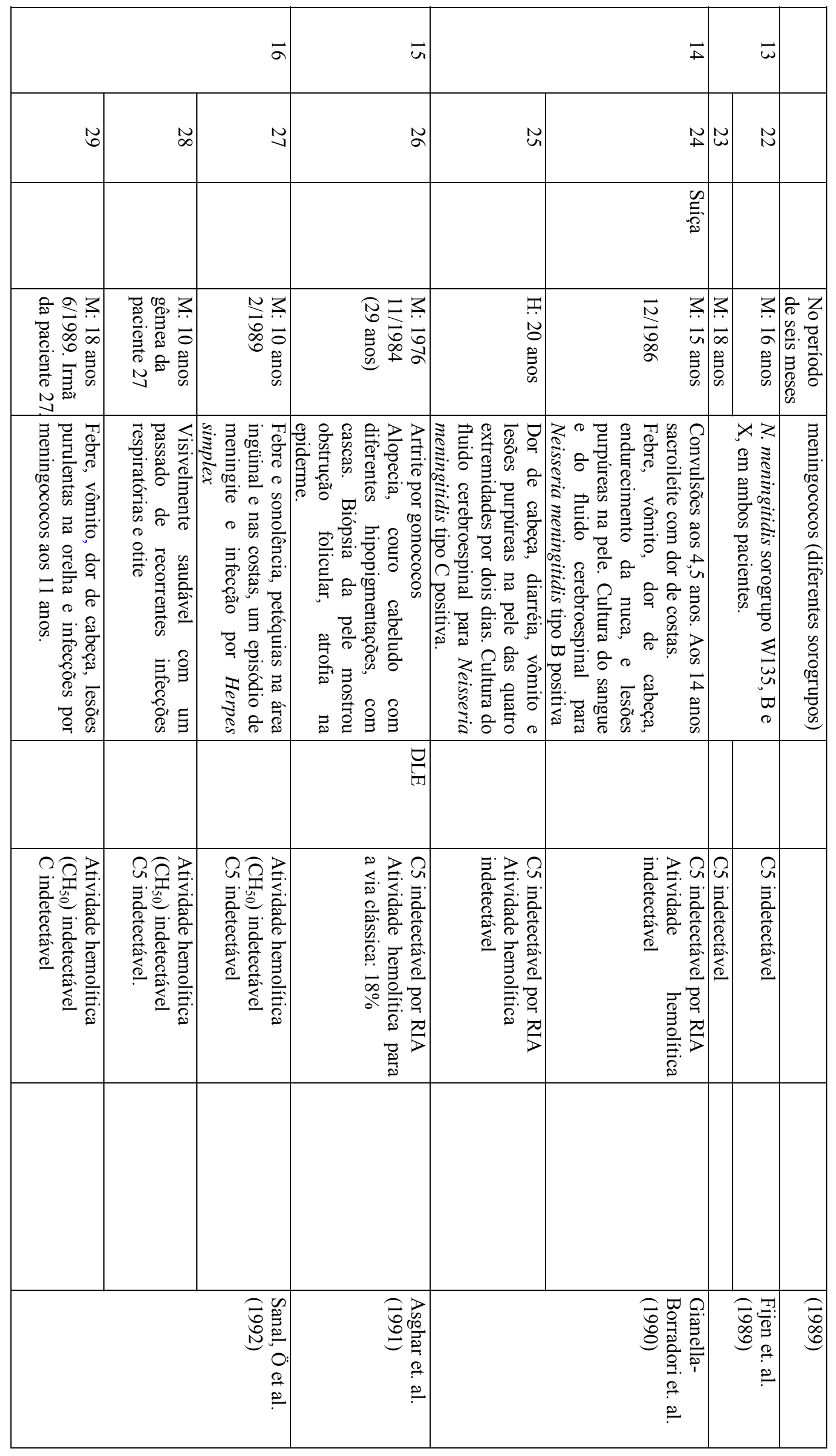




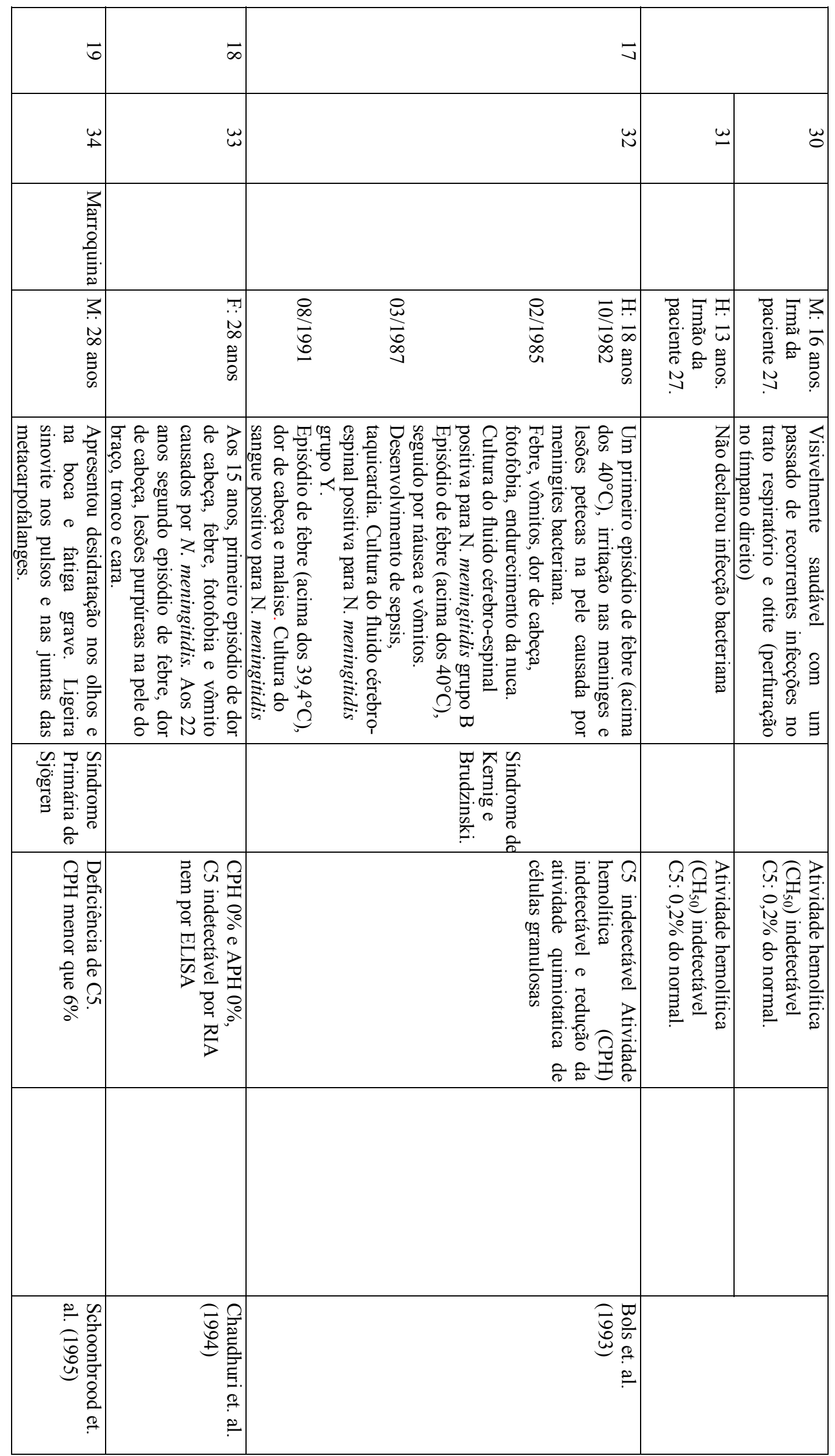




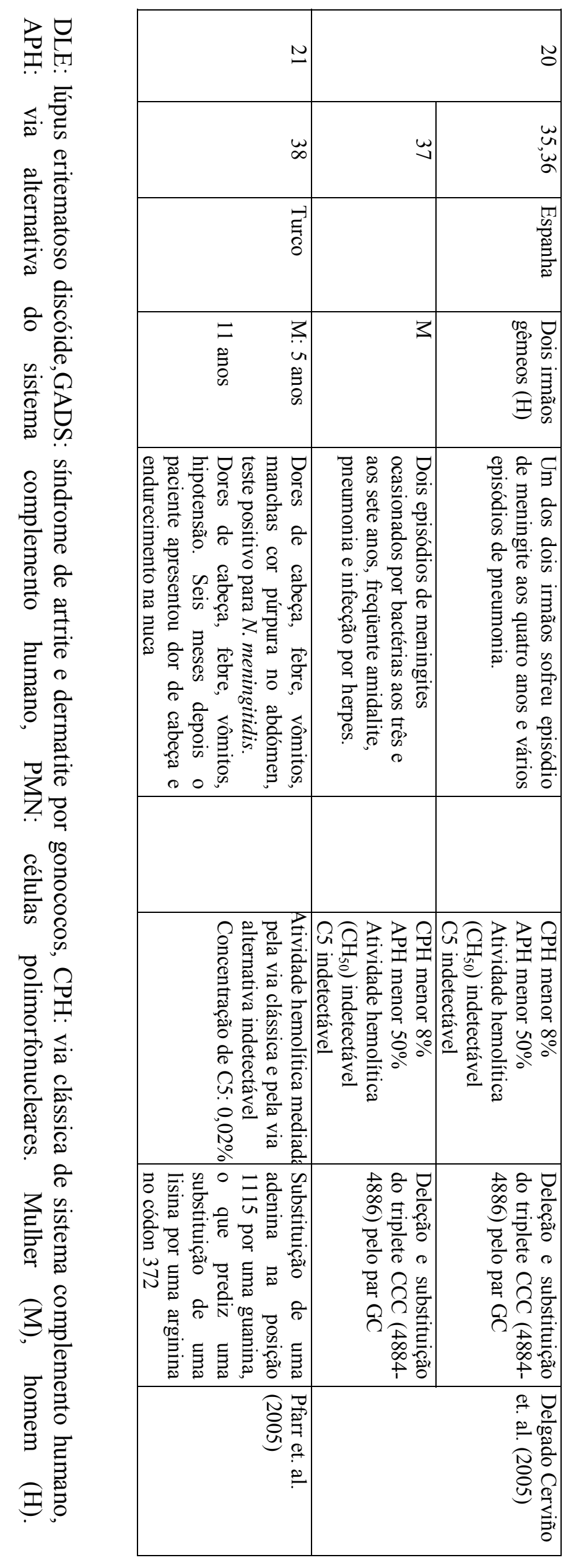




\section{OBJETIVOS GERAIS}

1. Caracterização genética e molecular da deficiência do componente C5 em uma família brasileira, onde cinco de dezessete membros já sofreram de meningite.

2. Determinar o tipo de mutação apresentada pelos indivíduos deficientes da proteína C5 pertencentes a esta família responsável pela ausência de C5. 


\section{MATERIAIS E MÉTODOS}

\subsection{Pacientes:}

Os indivíduos deficientes (II.9, II:4 e II:5) são provenientes de uma família brasileira bastante numerosa com história de consangüinidade (casamento entre primos-irmãos) (Figura 12) que têm sido acompanhados pela Dra. BeAtriz Costa CARVAlHo do Departamento de Alergia, Imunologia Clínica e Reumatologia, Escola Paulista de Medicina (UNIFESP). Após consentimento informado e aprovação pela Comissão de Ética do ICB, amostras de sangue e biópsias de pele foram obtidos por médico especializado.

A mãe (I:1) teve dois casamentos consangüíneos em segundo grau. No primeiro casamento teve um casal de filhos, sendo que a filha teve duas meninas, a primeira que faleceu de meningite tuberculosa aos sete anos de idade e a segunda menina (III:1) desenvolveu um quadro de meningite. No seu segundo casamento ela teve duas filhas, cinco filhos e três abortos com o indivíduo I:2 (Figura 12).

O indivíduo II:9 apresentou meningite aos três meses de idade, quando foi internado por quatorze dias. Aos nove meses de idade apresentou um segundo quadro de meningite iniciado por convulsões e febre, sendo novamente internado por 13 dias. Aos onze anos de idade, o individuo II:9 apresentou seu terceiro caso de meningite sendo internado por 11 dias, quando permaneceu um dia na unidade de terapia intensiva. Em todos os internamentos, o paciente apresentou manchas pelo corpo e os médicos relataram ter sido causado por meningite bacteriana. Em nenhum dos episódios de meningite, o agente etiológico foi isolado e identificado. Este paciente apresentou também um episódio de otite e diversos quadros virais sem complicações.

A concentração das classes de imunoglobulinas séricas aos treze anos de idade com exceção da IgE encontrava-se em concentrações normais (Quadro 1) Nesta idade, a produção de anticorpos: anti-tétano, anti-difteria e anti-sarampo foi 1,$19 ; 1,0$ e $0,68 \mathrm{mg} / \mathrm{dl}$ 
respectivamente. A produção dos anticorpos para pneumococos pré- e pós-imunização encontram-se no Quadro 4, onde o soro do indivíduo II:9 apresentou uma alta concentração de anticorpos anti-pneumococos pré- e pós-imunização para o sorotipo 14 . O soro do indivíduo II:9 não foi reagente para HIV. O número de células sangüíneas (Quadro 2), concentração de hemoglobina e a porcentagem de hematócrito (Quadro 3) para este indivíduo encontravam-se dentro da normalidade.

O indivíduo II:4 (irmã do paciente II:9) teve meningite meningocócica aos 4 meses e aos 27 anos de idade e também aqui desconhecemos qual foi o agente etiológico causador destas meningites.

Quadro 1. Concentração das classes de imunoglobulinas no soro do probando II:9, determinadas por imunodifusão radial.

\begin{tabular}{|l|l|l|}
\hline & Indivíduo II:9 & Valores Normais* \\
\hline IgG & $1750 \mathrm{mg} / \mathrm{dl}$ & 680 a $1601 \mathrm{mg} / \mathrm{dl}$ \\
\hline IgA & $190 \mathrm{mg} / \mathrm{dl}$ & 60 a $336 \mathrm{mg} / \mathrm{dl}$ \\
\hline IgM & $384 \mathrm{mg} / \mathrm{dl}$ & 88 a $378 \mathrm{mg} / \mathrm{dl}$ \\
\hline IgE & $19,4 \mathrm{UI} / \mathrm{dl}$ & Traços \\
\hline
\end{tabular}

* valores normais para crianças brasileiras saudáveis com mais de 10 anos de idade. Dados obtidos da tese de Maria Danisi Fujimura. Níveis séricos das subclasses da Imunoglobulina G em crianças normais e nefróticas. 1991. Tese de Doutorado em Medicina (Pediatria) Universidade de São Paulo. Testes realizados no Departamento de Alergia, Imunologia Clínica e Reumatologia da Escola Paulista de Medicina, UNIFESP. 
Quadro 2. Contagem diferencial de células sangüíneas no probando II:9

\begin{tabular}{|l|c|c|}
\hline & \multicolumn{2}{|c|}{$N^{\circ}$ Total $\left(\mathrm{mm}^{3}\right.$ de sangue) } \\
\hline Tipo Celular & Probando II:9 & Valores Normaís* \\
\hline Leucócitos & 5900 & 6000 a 15000 \\
\hline Segmentados & 3445 & 100 a 300 \\
\hline Eosinófilos & 159 & 0 a 50 \\
\hline Basófilos & 47 & 1500 a 4000 \\
\hline Linfócitos totais & 1840 & 200 a 950 \\
\hline Monócitos & 407 & \\
\hline
\end{tabular}

* Intervalo de normalidade, referente a adultos (THORN et al, 1977, com exceção dos números totais de leucócitos que são referentes a crianças brasileiras de 4 a 7 anos (CARVALHO 1994). Testes realizados no Departamento de Alergia, Imunologia Clínica e Reumatologia da Escola Paulista de Medicina, UNIFESP.

Quadro 3. Provas hematológicas realizadas com o probando II:9

\begin{tabular}{|l|c|c|}
\hline & \multicolumn{2}{|c|}{$N^{o}$ Total $\left(\mathrm{mm}^{3}\right.$ de sangue) } \\
\hline & Probando II:9 & Valores Normaís* \\
\hline Hematócrito (\%) & 42 & $41,5-50,4$ \\
\hline Hemoglobina (g/dL) & 13,9 & $14-17,4$ \\
\hline
\end{tabular}

* Intervalo de normalidade para homens adultos (WINTROBE, 1988), (dados fornecidos pela Dra. Beatriz Costa-Carvalho).

Quadro 4. Anticorpos produzidos pelo indivíduo II:9 de diferentes sorotipos contra pneumococos $(\mathrm{mg} / \mathrm{ml})$.

\begin{tabular}{|l|l|l|l|l|l|l|}
\hline Sorotipo & 1 & 3 & 5 & 6 & 9 & 14 \\
\hline Pré-Imunização & 0,71 & 0,32 & 2,4 & 1,7 & 0,54 & 23 \\
\hline Pós-Imunização & 1,5 & 0,65 & 2,1 & 2,1 & 0,95 & 11,1 \\
\hline
\end{tabular}

(dados fornecidos pela Dra. Beatriz Costa-Carvalho, UNIFESP). 


\subsection{Cultura de Fibroblastos}

Os fibroblastos foram empregados como fonte de DNA e de RNAm e seu cultivo foi feito a partir de biópsias de pele de aproximadamente $3 \mathrm{~mm}^{2}$ retiradas dos probandos, familiares e indivíduos normais (controles). Os fragmentos da pele biopsiada foram cortados em pedaços menores e transferidos para placas de seis câmaras contendo uma gota de meio "DMEM" (Dulbbeco's Modified Eagle's Medium - Sigma) suplementado com L-glutamina a 2 $\mathrm{mM}$, penicilina a $50 \mathrm{U} / \mathrm{mL}$ e $10 \%$ de soro bovino fetal (SBF - Invitrogen) inativado a $56{ }^{\circ} \mathrm{C}$ por 30 min. Para facilitar a aderência das células à placa, empregou-se uma lamínula de vidro sobre o fragmento de pele, pressionando-o suavemente. Sobre a lamínula colocamos $5 \mathrm{~mL}$ de meio DMEM e as culturas foram mantidas a $37{ }^{\circ} \mathrm{C}$ sob tensão de $5 \%$ de $\mathrm{CO}_{2}$, onde após algumas semanas, os fibroblastos começaram a proliferar. Quando as células começaram a ocupar todo o fundo da lamínula e placa, elas foram removidas com solução de tripsina $0,1 \%$ e repicadas (as células podem ser utilizadas até o repique 12) ou congeladas. Os fibroblastos foram congelados em $90 \%$ de SBF e $10 \%$ de dimetil sulfóxido (Sigma) e mantidos em nitrogênio líquido até o momento de utilização. As células descongeladas foram cultivadas em garrafa de cultura contendo $15 \mathrm{~mL}$ de meio DMEM suplementado com SBF (10\%) e glutamina $\left(1 \%\right.$ a $37^{\circ} \mathrm{C}$, sob tensão de $5 \%$ de $\mathrm{CO}_{2}$ até proliferação e posterior extração do RNA total ou repique.

\subsection{Imunodifusão Dupla (OUCHTERLONY, 1978)}

Esta técnica foi usada para determinação da presença de proteínas do sistema complemento nos soros dos pacientes e seus familiares e posterior comparação com soros controles. Numa primeira etapa, o sangue foi coletado e centrifugado a $350 \mathrm{~g}$ por $10 \mathrm{~min}$ a 4 ${ }^{\circ} \mathrm{C}$. O soro foi aliquotado e congelado a $-80^{\circ} \mathrm{C}$, até o momento de uso. Uma camada de gel de agarose a $1 \%$ foi previamente colocada sobre uma lâmina de vidro $(10 \mathrm{~cm} \mathrm{x} 4 \mathrm{~cm})$ e, após 
secagem, recebeu um segundo revestimento com gel de agarose a $1 \%$ em solução salina tamponada com fosfato (PBS) pH:7,2 ( $\mathrm{KH}_{2} \mathrm{PO}_{4}$ a $5 \mathrm{mM}, \mathrm{K}_{2} \mathrm{HPO}_{4}$ a $1,2 \mathrm{mM}$ e NaCl $\left.150 \mathrm{mM}\right)$. Em orifícios de $\sim 3 \mathrm{~mm}$ de diâmetro, foram colocados 7,5 $\mu \mathrm{L}$ de soro puro anti-C5 humano produzido em coelho (Calbiochem-Novabiochem) contra 7,5 $\mu \mathrm{L}$ de cada um dos soros de interesse, sem diluir. A reação foi incubada em câmara úmida a $4{ }^{\circ} \mathrm{C}$ por $48 \mathrm{~h}$, para permitir a difusão de proteínas séricas e precipitação de imunocomplexos. As lâminas foram lavadas com excesso de PBS por $48 \mathrm{~h}$, secadas e coradas com Coomassie blue.

\subsection{Imunodifusão Radial}

Este método (MANCINI et al., 1965), foi usado para a quantificação de proteínas do sistema complemento (C3, C4, Fator H, Fator I e Fator B) nos soros dos pacientes e seus familiares. Sobre uma superfície plana, uma lâmina de vidro $(8 \mathrm{~cm} \times 8 \mathrm{~cm})$ foi revestida primeiramente com $2 \mathrm{~mL}$ de agarose a $1 \%$ em PBS e, após secagem, foi coberta com agarose a $1 \%$ em PBS contendo $1 \%$ de anticorpos específicos (anti-C3, anti-C4, anti-Fator I, antiFator $\mathrm{H}$ ou anti-Fator B). A seguir, colocamos dentro de poços de $3 \mathrm{~mm}$ de diâmetro $5 \mu \mathrm{L}$ das amostras de interesse (soros dos probandos e familiares). Para a construção da curva-padrão, aplicamos $5 \mu \mathrm{L}$ de uma mistura de 47 soros de pessoas saudáveis, pura (100\%) ou diluída a $50 \%, 25 \%$ e $12,5 \%$. As placas foram incubadas por $24-48 \mathrm{~h}$ em câmara úmida mantida a 4 ${ }^{\circ} \mathrm{C}$ para difusão e formação do halo de precipitação, seguido por lavagem com excesso de PBS por 48 h, secagem e coloração com Coomassie Blue. Para a construção da curva padrão, as diluições do soro correspondem aos valores de " $x$ " e o diâmetro dos halos em mm foi expressado nas ordenadas “y” Com a média destes dados, construímos a equação da reta $y=a$ $x+b$, para calcular a concentração das proteínas de complemento no soro dos pacientes e familiares. Este ensaio foi realizado em triplicata conforme demonstrado na Tabela 10, onde se mostra a média destes três experimentos. 


\subsection{Atividade hemolítica mediada pela Via Clássica}

O volume de $4 \mathrm{~mL}$ de suspensão de hemácias de carneiro foi lavado 3 X com $10 \mathrm{~mL}$ de tampão Complement Fixation Buffer "CFD" 1X (barbitona sódica a $4 \mathrm{mM}, \mathrm{NaCl}$ a 0,145 $\mathrm{M}, \mathrm{MgCl}_{2}$ a $0,83 \mathrm{mM}$ e $\mathrm{CaCl}_{2}$ a $0,25 \mathrm{mM}$ ), centrifugando-se a $600 \mathrm{~g}$. As hemácias foram ressuspensas a $10 \%$ em tampão CFD e sensibilizadas a $4^{\circ} \mathrm{C}$ por $30 \mathrm{~min}$ com soro de coelho anti carneiro E (A) em dose sub-aglutinante. Após este período, a suspensão (EA) foi lavada 1X com tampão CFD.

As placas $(8 \mathrm{~cm}$ X $8 \mathrm{~cm}$ ) foram preparadas com $10 \mathrm{~mL}$ de agarose em tampão CFD a 1,2 \%, contendo $500 \mu \mathrm{L}$ de EA. Poços de aproximadamente $3 \mathrm{~mm}$ de diâmetro foram preparados e preenchidos com 7,5 $\mu \mathrm{L}$ de uma mistura não diluída de soros do 24 indivíduos adultos saudáveis ou diluída em tampão CFD para a formação da curva padrão (100 \%, 75 \%, $50 \%$ e $25 \%$ ), assim como $7,5 \mu \mathrm{L}$ de cada soro de interesse (100\% e $50 \%$ ) mantidos a -70 ${ }^{\circ} \mathrm{C}$ até o momento de uso. A placa foi então incubada por $18 \mathrm{~h}$ a $4^{\circ} \mathrm{C}$ para difusão das proteínas de complemento e por mais $2 \mathrm{~h}$ a $37{ }^{\circ} \mathrm{C}$ para propiciar a lise mediada pela via clássica.

Para a construção da curva padrão, consideramos a \% de diluição do soro como " $x$ " e o diâmetro do halo de lise foi medido em mm ("y") e com a média destes dados construímos a equação da reta $y=a x+b$. As determinações sempre foram feitas com os soros dos pacientes puros ou diluídos a $50 \%$, em duplicatas.

\subsection{Atividade hemolítica mediada pela Via Alternativa}

O volume de $5 \mathrm{~mL}$ do tampão GVB-EGTA- $\mathrm{Mg}^{2+} \mathrm{pH} 7,4\left(2,5 \mathrm{~mL}\right.$ a $0,2 \mathrm{M}$ de $\mathrm{MgCl}_{2}, 5$ $\mathrm{mL}$ a $0,2 \mathrm{M}$ de EGTA e $92,5 \mathrm{~mL}$ de $1 \mathrm{X}$ "GVB") foi aquecido e misturado a $4 \mathrm{~mL}$ de agarose a $2 \%$ no mesmo tampão a $56{ }^{\circ} \mathrm{C}$ em banho-maria. A preparação foi transferida para outro banho-maria mantido a $45{ }^{\circ} \mathrm{C}$, quando foram adicionados $512 \mu \mathrm{L}$ de hemácia de cobaia a 10 
\% no mesmo tampão GVB-EGTA- $\mathrm{Mg}^{2+}$, tendo sido previamente lavada por três vezes no tampão acima. A mistura foi despejada sobre placa de vidro $(8 \mathrm{~cm} \mathrm{X} 8 \mathrm{~cm})$, aguardando-se a solidificação do gel. Para a construção da curva padrão, aplicamos 7,5 $\mu \mathrm{L}$ de uma mistura de soros do 46 indivíduos adultos saudáveis, pura (100\%) e em diluições feitas em tampão GVB/EGTA/ $\mathrm{Mg}^{2+}(75 \%, 50 \%$ e $25 \%$ ) dentro dos poços de $3 \mathrm{~mm}$ de diâmetro feitos sobre a placa, assim como $7,5 \mu \mathrm{L}$ dos soros de interesse. A placa foi então mantida em câmara úmida a $4{ }^{\circ} \mathrm{C}$ para difusão das proteínas de complemento por $14 \mathrm{~h}$ e a $37^{\circ} \mathrm{C}$ por $2 \mathrm{~h}$ para que pudesse acontecer a lise das hemácias pelas proteínas de complemento.

Em alguns experimentos a atividade hemolítica mediada pela via clássica foi avaliada em soros diluídos (1:2) com soro humano normal (SHN), soro deficiente de C1s (C1sD) ou com soro deficiente de C2 (C2D). Além disso, em outros experimentos C5 humano purificado (Calbiochem-Novabiochem) foi adicionado ao soro C5D nas concentrações de 266, 133, 66 e $33 \mu \mathrm{g} / \mathrm{mL}$, e sua atividade hemolítica foi avaliada tanto pela via alternativa quanto pela via clássica, incubando-se as placas de hemólise por $18 \mathrm{~h}$ a $4^{\circ} \mathrm{C}$, seguido por $2 \mathrm{~h}$ a $37^{\circ} \mathrm{C}$.

\subsection{Enzyme-linked Immunosorbent Assay (ELISA)}

Anticorpos policlonais monoespecíficos anti-C5 humano (feitos em coelho, Calbiochem- NovaBiochem) diluídos 1:4000 em tampão carbonato pH 9,6 $\left(\mathrm{NaHCO}_{3}\right.$ 0,1 $\mathrm{M}$ e $\mathrm{Na}_{2} \mathrm{CO}_{3} 0,1 \mathrm{M}$ ) foram incubados em placas de 96 poços por cerca de $14 \mathrm{~h}$ a $4^{\circ} \mathrm{C}$. A remoção dos anticorpos excedentes foi feita mediante a lavagem com PBS contendo Tween 20 (Tween $200,05 \%, \mathrm{NaN}_{3} 0,02 \%, \mathrm{NaCl} 0,15 \mathrm{M}, \mathrm{Na}_{2} \mathrm{PO}_{4} 10 \mathrm{mM}$ ) seguido por bloqueio com leite (em pó e desnatado) a 5\% em PBS contendo Tween 20 a $0,05 \%$, por $2 \mathrm{~h}$ à temperatura ambiente com o intuito de diminuir as reações inespecíficas. As amostras de interesse como dos probandos e familiares foram diluídas em leite desnatado 5\% em PBS contendo Tween 20 (1/252 e 1/4, respectivamente) e aplicadas à placa previamente sensibilizada com o anti-C5 (feito em 
coelho, Calbiochem-Novabiochem), incubando-se por $2 \mathrm{~h}$ a $37^{\circ} \mathrm{C}$. Após 5 lavagens, adicionamos o segundo anticorpo, anti-C5 humano (feito em carneiro, The Binding Site) quando a placa foi novamente incubada por mais $2 \mathrm{~h}$ a $37^{\circ} \mathrm{C}$. Após novas lavagens, foi adicionado o terceiro anticorpo (anti-IgG de carneiro conjugado à fosfatase alcalina, Calbiochem-Novabiochem) diluído a 1:5000 em leite desnatado 5\% em PBS contendo Tween 20 pelo mesmo período. Finalmente, a placa depois de lavada, recebeu a solução reveladora [tampão para fosfatase alcalina $\mathrm{pH}: 8,0$ (dietanolamina $10 \%, \mathrm{NaN}_{3}, \mathrm{MgCl}_{2}$ ) e $0,1 \%$ de pnitrofenil fosfato disódico (PNPP) - Calbiochem-NovaBiochem)] por $30 \mathrm{~min}$ ao abrigo da luz, lendo-se a absorbância a $405 \mathrm{~nm}$. A construção da equação da reta y = a $(\ln x)+b$ foi feita empregando diversas diluições de C5. A concentração inicial de $300 \mu \mathrm{g} / \mathrm{ml}$ de C5 purificado foi diluída $1 / 128,1 / 256,1 / 512,1 / 1024,1 / 2048,1 / 4096,1 / 8192$ e 1/16384 vezes em 5\% de leite desnatado em PBS contendo Tween 20 a $0,05 \%$.

\subsection{Extração do RNA total}

Para a extração do RNA total, as células (aproximadamente 4 x $10^{6}$ células $/ \mathrm{ml}$ ) foram lavadas com PBS gelado pH:7,2 $\left(\mathrm{KH}_{2} \mathrm{PO}_{4}\right.$ a $5 \mathrm{mM}, \mathrm{K}_{2} \mathrm{HPO}_{4}$ a $1,2 \mathrm{mM}$ e $\left.\mathrm{NaCl} 150 \mathrm{mM}\right)$ e lisadas com ajuda de um raspador em $500 \mu \mathrm{L}$ de solução de desnaturação (citrato de sódio $\mathrm{pH}: 6,8$ a $26 \mathrm{mM}$, N-lauril sarcosina $0,5 \%$; $\beta$-mercaptoetanol a $0,125 \mathrm{M}$ e tiocianato de guanidina a $4 \mathrm{M}$ ). As células lisadas foram transferidas para microtubos de 1,5 $\mathrm{ml}$ nos quais foram adicionados $50 \mu \mathrm{L}$ de acetato de amônio $2 \mathrm{M}$ e $500 \mu 1$ solução de fenol clorofórmioálcool isoamílico. Depois de $15 \mathrm{~min}$ a $0{ }^{\circ} \mathrm{C}$, as células foram centrifugadas por $20 \mathrm{~min}$ a $12.000 \mathrm{~g}, \mathrm{a} 4^{\circ} \mathrm{C}$. O sobrenadante contendo RNA foi transferido para outro microtubo, onde o mesmo volume de isopropanol foi adicionado para precipitação do RNA, incubando-se a $20^{\circ} \mathrm{C}$ por $18 \mathrm{~h}$. Após esse procedimento, o conteúdo foi centrifugado por 40 min a $15000 \mathrm{~g}$ a $4^{\circ} \mathrm{C}$. O sobrenadante foi desprezado e o precipitado lavado com $1 \mathrm{~mL}$ de $\mathrm{EtOH} 75 \%$, sob uma 
nova centrifugação a $15000 \mathrm{~g}$ e a $4^{\circ} \mathrm{C}$, por $20 \mathrm{~min}$. $\mathrm{O} \mathrm{EtOH}$ foi desprezado e o precipitado contendo RNA total foi ressuspenso em $10 \mu \mathrm{l}$ de água estéril, livre de RNAse (Promega). Até o momento de uso, as amostras de RNA foram mantidas a $-20^{\circ} \mathrm{C}$. O RNA total extraído dos fibroblastos foi quantificado, após absorbância lida em espectrofotômetro (260 nm), aceitando-se a relação da D.O $260 \mathrm{~nm} / \mathrm{D} . \mathrm{O} 280 \mathrm{~nm}$ entre o 1,7 a 2,0.

\subsection{Extração do DNA genômico}

Para a extração do DNA genômico, os fibroblastos (aproximadamente $4 \times 10^{6}$ células $/ \mathrm{mL}$ ) foram removidos com solução de tripsina $0,1 \%$, centrifugados $(350 \mathrm{~g}$ por $10 \mathrm{~min}$ a $\left.4{ }^{\circ} \mathrm{C}\right)$, posteriormente lavados com PBS gelado $\mathrm{pH}: 7,2\left(\mathrm{KH}_{2} \mathrm{PO}_{4}\right.$ a $5 \mathrm{mM}, \mathrm{K}_{2} \mathrm{HPO}_{4}$ a 1,2 $\mathrm{mM}$ e $\mathrm{NaCl} 150 \mathrm{mM}$ ). Para a lise e posterior precipitação do DNA, adicionou-se $0,5 \mathrm{~mL}$ de DNAzol (INVITROGEN) e, depois de homogenizado, adicionou-se então 0,3 $\mathrm{ml}$ de etanol (100\%), centrifugando-se a $1000 \mathrm{~g}$ por $10 \mathrm{~min}$ a $4^{\circ} \mathrm{C}$. Retirou-se o sobrenadante e o sobrenadante foi lavado com $1 \mathrm{~mL}$ de etanol (95\%). Após secagem, o precipitado foi ressuspenso em 200 $\mu \mathrm{L}$ de tampão de eluição "TE" (10mM Tris-HCl- pH 8,0; 0,1mM EDTA).

\subsection{Reverse Transcriptase - Polymerase Chain Reaction RT-PCR "One Step"}

Após quantificação do RNA total, a RT-PCR foi iniciada da seguinte maneira, para 50 $\mu \mathrm{L}$ de reação final de RT-PCR foram utilizados reagentes nas seguintes concentrações finais: $25 \mu \mathrm{L}$ de $2 X$ Reaction Mix (Invitrogen); $10 \mu \mathrm{L}$ de RNA total a $30 \mathrm{ng} / \mu \mathrm{L}, 2 \mu \mathrm{L}$ de primers específicos a uma concentração de 20 pmoles/ $\mu \mathrm{L}$ (Tabela 1, primers C5 HU 1F, C5 HU 45F, C5 HU 587R, C5 HU 3210F e C5 HU 4050R); $1 \mu 1$ de SuperScript ${ }^{\mathrm{TM}}$ II RT/ Platinum ${ }^{\circledR T a q}$ Mix e $10 \mu 1$ de água autoclavada livre de RNAse. As reações de amplificação ocorrerão nas seguintes condições: 30 min a $50^{\circ} \mathrm{C}$, para a síntese da fita de cDNA; 2 min a $94^{\circ} \mathrm{C} ; 35$ ciclos de $30 \mathrm{~s}$ de desnaturação a $94{ }^{\circ} \mathrm{C}, 30 \mathrm{~s}$ de anelamento a $55{ }^{\circ} \mathrm{C}$ (vide Tabela 1) e $1 \mathrm{~min}$ para 
extensão a $72{ }^{\circ} \mathrm{C}$; seguidos por mais 7 min de extensão a $72{ }^{\circ} \mathrm{C}$. Como controle positivo, usamos na reação de amplificação oligonucleotídeos específicos para GAPDH (gliceraldeído 3-fosfato deshidrogenase) expressado constitutivamente pelas células. Para verificar se houve alguma contaminação na etapa de preparação da reação, incluímos um controle negativo feito com todos os reagentes citados no RT-PCR e PCR, porém sem a inclusão do cDNA.

\subsection{RT-PCR “Two Steps” - Promega}

Após quantificação do RNA, procedeu-se com a RT-PCR em dois passos: o primeiro para a obtenção do cDNA e o segundo para amplificação do fragmento de cDNA desejado. Na primeira etapa, foram misturados $2,5 \mu \mathrm{L}$ de RNA total a $600 \mathrm{ng} / \mu \mathrm{l}$ e $4 \mu \mathrm{L}$ de oligo d(T) a $500 \mathrm{ng} / \mu 1$ por 5 min a $70^{\circ} \mathrm{C}$, onde acontece a ligação do oligo $\mathrm{d}(\mathrm{T})$ à cauda de poli $(\mathrm{A})$. Em seguida, foram adicionados os reagentes nas concentrações iniciais de $5 \mu \mathrm{L}$ de tampão $5 \mathrm{X}$ para a enzima M-MLV transcriptase reversa $(250 \mathrm{mM}$ Tris- $\mathrm{HCl} \mathrm{pH} 8,3,375 \mathrm{mM} \mathrm{KCl}, 15 \mathrm{mM}$ $\mathrm{MgCl}_{2}, 50 \mathrm{mM}$ DTT da Promega); $1 \mu \mathrm{L}$ de inibidor de RNAse (GE Healthcare); 0,5 $\mu \mathrm{L}$ de dNTP a 10mM; 0,7 $\mu \mathrm{L}$ de M-MLV transcriptase reversa $200 \mathrm{U} / \mu 1$ (Promega) e água autoclavada, livre de DNAse e RNAse, até completar o volume final de $25 \mu 1$. Esta primeira reação foi incubada por $1 \mathrm{~h} \mathrm{a} 42{ }^{\circ} \mathrm{C}$ para obtenção da primeira fita de cDNA. Para amplificar o fragmento desejado, empregamos $2,5 \mu 1$ do produto de cDNA; $2,5 \mu 1$ de tampão $10 \mathrm{X}$ para a enzima Taq DNA polimerase (200 mM Tris- $\mathrm{HCl}(\mathrm{pH} 8.0)$ e $500 \mathrm{mM} \mathrm{KCl}) ; 0,75 \mu \mathrm{L}$ de $\mathrm{MgCl}$ a $50 \mathrm{mM} ; 0,5 \mu \mathrm{L}$ de dNTPs a $10 \mathrm{mM}$; primers específicos a uma concentração de 30 pmols cada (Quadro 5); 0,5 $\mu \mathrm{L}$ de Taq DNA polimerase recombinante a $5 \mathrm{U} / \mu \mathrm{L}$ (Invitrogen) e água autoclavada livre de DNAse e RNAse até se completar $25 \mu 1$ de reação. Estas reações aconteceram nas condições seguintes: 2 min a $95{ }^{\circ} \mathrm{C} ; 1$ min a $94{ }^{\circ} \mathrm{C}$ para a desnaturação inicial e 36 ciclos de: 1 min de desnaturação a $94{ }^{\circ} \mathrm{C}, 40 \mathrm{~s}$ a diversas temperaturas de anelamento (Quadro 5) e 2 min de extensão a $72{ }^{\circ} \mathrm{C}$, seguidos por mais 7 min de extensão final a $72{ }^{\circ} \mathrm{C}$. 
A Taq (Thermus aquaticus) DNA polimerase recombinante foi adicionada em dois tempos, uma primeira metade no momento da preparação da reação de amplificação e a segunda metade no ciclo número 20 na etapa de extensão.

Os resultados foram analisados após eletroforese em gel de agarose a $1 \%$ preparado com TBE $1 \mathrm{X}$ pH 8,0 (ácido bórico a 100mM, Tris a $100 \mathrm{mM}$ e $0,4 \%$ de EDTA - 2mM), empregando-se marcadores para a estimativa do tamanho dos produtos de DNA amplificados. A corrida eletroforética ocorreu a $60 \mathrm{~V}$ por $1 \mathrm{~h}$. Em seguida, o gel foi corado com solução de brometo de etídeo $10 \mathrm{mM}$, por $15 \mathrm{~min}$, para revelar as bandas de cDNA de C5 (Figura 11).

Como controle positivo, empregamos oligonucleotídeos específicos do gene de GAPDH (gliceraldeído 3-fosfato deshidrogenase) que por ser uma enzima expressada constitutivamente nos humanos, é usado para assegurarmo-nos que não introduzimos artefatos técnicos no experimento. Para verificar se acontecia alguma contaminação na etapa de preparação de amostras, uma amostra contendo todos os reagentes citados no RT-PCR e PCR, mas sem inclusão do cDNA (controle negativo).

\subsection{Extração de DNA a partir do gel}

O protocolo abaixo foi empregado para purificação e obtenção de regiões de cDNA para posterior seqüenciamento de nucleotídeos. Os produtos amplificados pela RT-PCR (50 $\mu \mathrm{L}$ ) foram separados eletroforeticamente em gel de agarose preparado a $1 \%$ em TBE $1 \mathrm{X}$ Como referência de tamanho, marcadores com tamanhos conhecidos de DNA foram incluídos. Após corrida eletroforética, o gel foi corado com solução de brometo de etídeo 10 $\mathrm{mM}$, por $15 \mathrm{~min}$, para revelar as bandas de DNA do gene C5. As bandas presentes foram cortadas do gel e colocadas num tubo ao qual foram adicionados $10 \mu \mathrm{L}$ de tampão da captura (fornecido pelo fabricante- Invitrogen) para cada 0,01 g de gel, incubando-se por $15 \mathrm{~min}$ a 50 ${ }^{\circ} \mathrm{C}$ em banho-maria. $\mathrm{O}$ conteúdo foi transferido para uma coluna de filtração, contendo sílica 
para a captura de DNA. Descartamos o gel com o tampão, adicionando-se $500 \mu \mathrm{L}$ de tampão de lavagem à coluna, a fim de descartar restos do gel na membrana sílica e finalmente a coluna de filtração foi transferida para outro tubo, onde foram adicionados $50 \mu \mathrm{L}$ de tampão de eluição "TE" (10mM Tris-HCl- pH 8,0; 0,1 mM EDTA) aquecido a $60{ }^{\circ} \mathrm{C}$, seguido por 1 min de descanso. A amostra foi centrifugada e o produto de DNA foi guardado a $-20^{\circ} \mathrm{C}$ para posterior seqüenciamento de nucleotídeos.

Semelhante procedimento foi adotado para obtenção de bandas de DNA genômico que foram encaminhadas para o seqüenciamento de nucleotídeos.

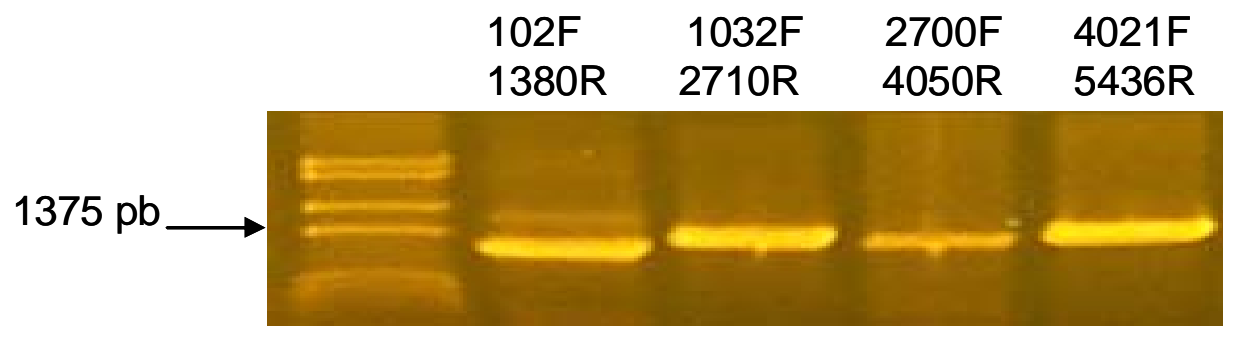

Figura 11. Expressão do gene $C 5$ em fibroblastos de indivíduos normais. Foram empregados os pares de oligonucleotídeos 102F - 1380R (1278 pb), 1321F - 2710R (1389 pb), 2700F 4050R (1350 pb) e 4021F - 5436R (1415 pb).

\subsection{Seqüenciamento de nucleotídeos}

Para a reação de seqüenciamento propriamente dita foram utilizados: $11 \mu \mathrm{L}$ do DNA purificado $(300 \mathrm{ng} / \mu \mathrm{L})$; para cada reação utilizou-se $1 \mu \mathrm{L}$ de um dos primers (3 pmoles $/ \mu \mathrm{L})$; $6 \mu \mathrm{L}$ de tampão de seqüenciamento (Tris- $\mathrm{HCl}$ a $200 \mathrm{mM}$ a $\mathrm{pH}=9, \mathrm{MgCl}$ a $5 \mathrm{mM}$ ) e $2 \mu \mathrm{L}$ da enzima Big Dye- Terminator V3.1 (Applied-Biosystem). A reação de seqüenciamento foi feita nas seguintes condições: $10 \mathrm{~s}$ a $96{ }^{\circ} \mathrm{C}, 5 \mathrm{~s}$ a $50{ }^{\circ} \mathrm{C}$ e 4 min a $60{ }^{\circ} \mathrm{C}$ por 40 ciclos. Em seguida, o DNA foi precipitado com $80 \mu \mathrm{L}$ de isopropanol a $75 \%$, durante 15 min à temperatura ambiente e centrifugado $15000 \mathrm{~g}$ por $20 \mathrm{~min}$. O sobrenadante foi aspirado e o precipitado foi 
lavado com $250 \mu \mathrm{L}$ de isopropanol a $75 \%$ e centrifugado por 5 min. O precipitado de DNA foi secado e logo solubilizado para aplicação no gel de seqüenciamento. A corrida em gel de seqüenciamento foi realizada no Departamento de Bioquímica do Instituto de Química da USP, com a colaboração do Dr. Shaker Chuck Farah.

As seqüências de nucleotídeos obtidas foram analisadas em nosso laboratório, utilizando o programa BLAST N (ALTSCHUL, et. al. 1997) com a referência gi|179982|gb|M57729.1|HUMCCC5[179982] Homo sapiens complement component C5 mRNA através do sítio http://www.ncbi.nlm.nih.gov/blast, e analisadas através do programa Chromas 1.62/2.21. 
Quadro 5. Oligonucleotídeos utilizados na PCR, RT-PCR e seqüenciamento, mostrando temperatura de anelamento, sentido da amplificação e tamanho em pares de base (pb) dos produtos amplificados do gene $C 5$.

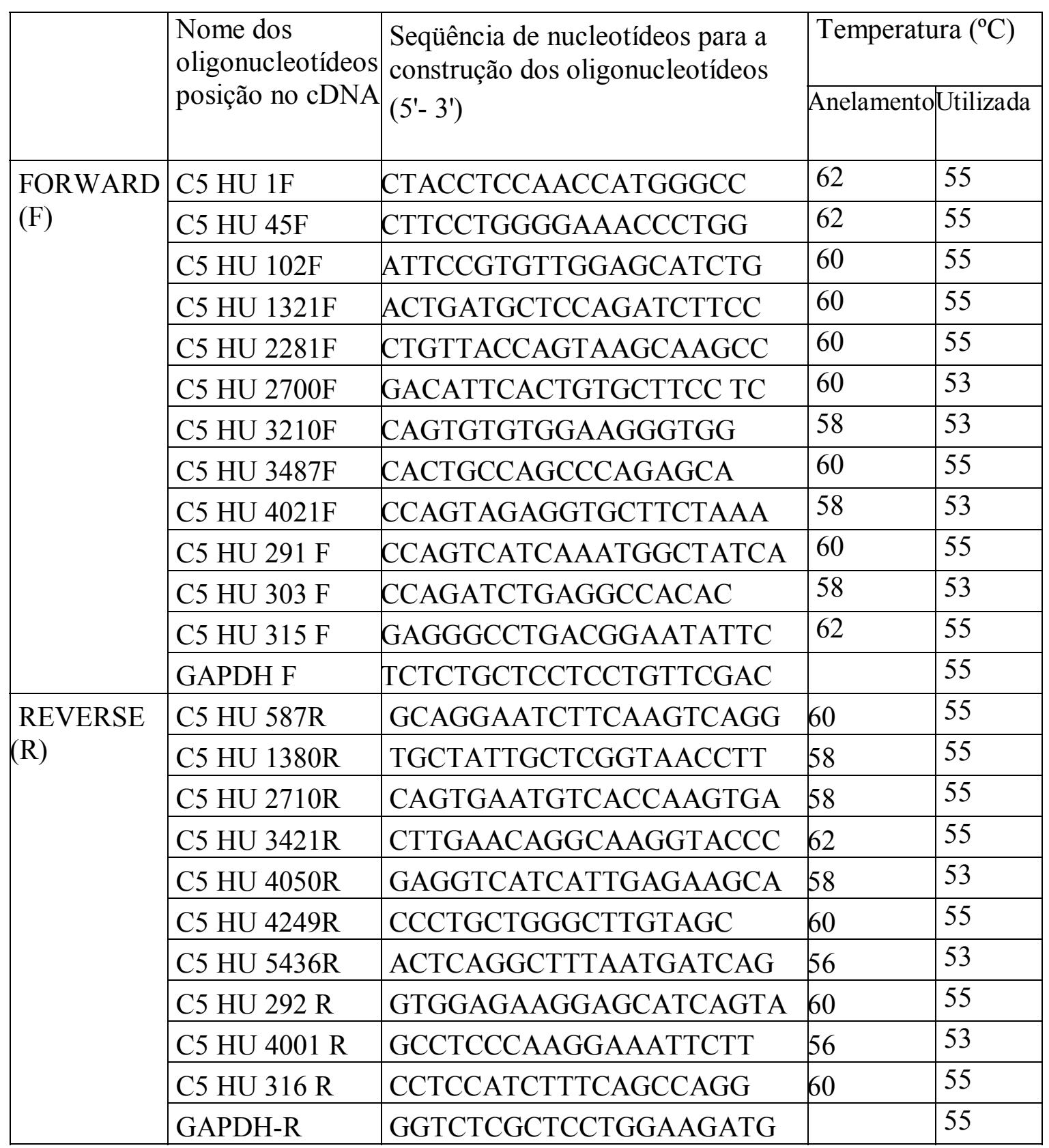




\section{14 Fluxograma do trabalho}

3.14.1 Determinação da Atividade Hemolítica mediada pela Via Clássica e Alternativa

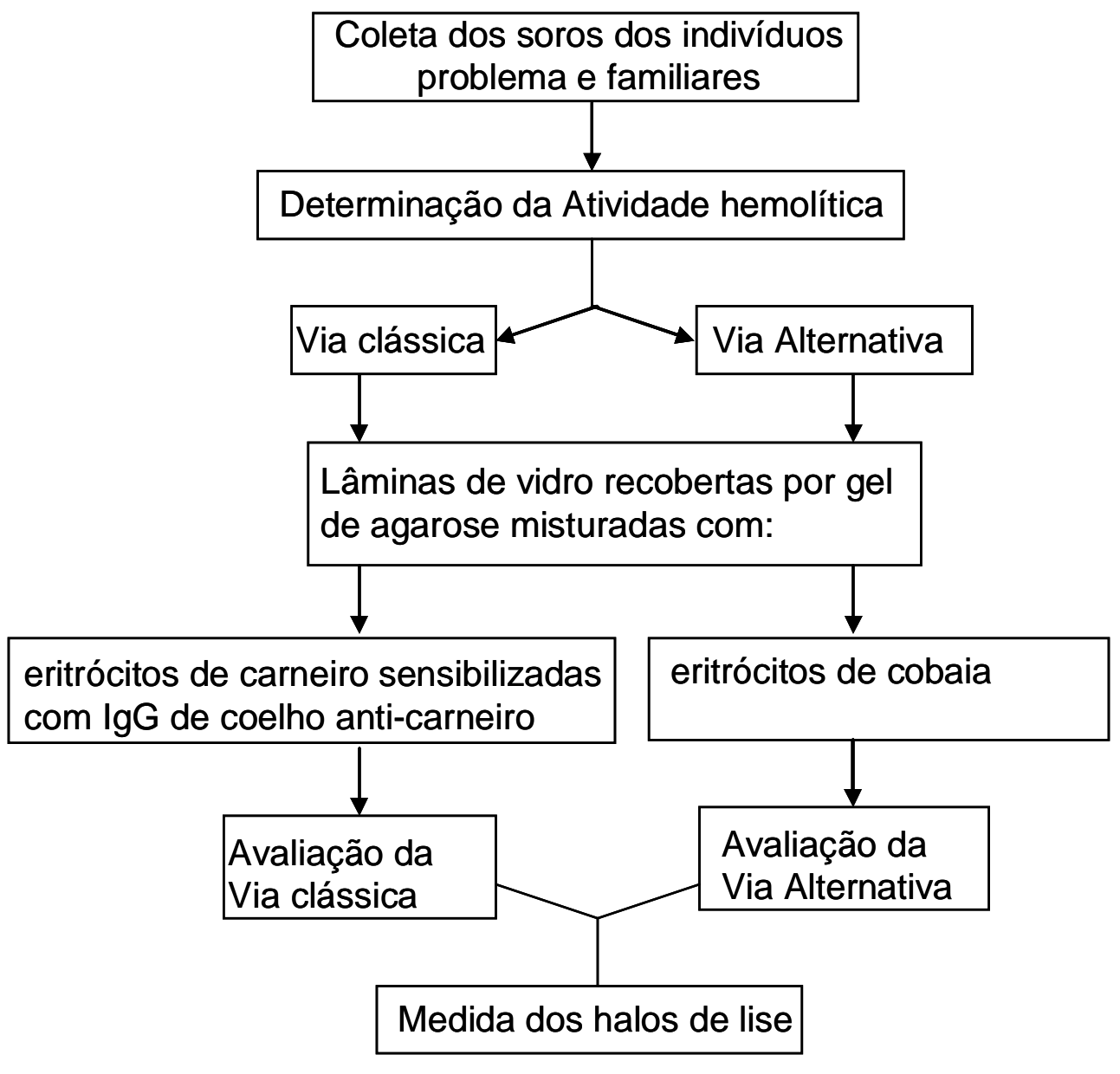

3.14.2 Determinação da concentração sérica das proteínas do sistema complemento nos indivíduos I:1, I:2, II:4, II:5, II:9 e famliares

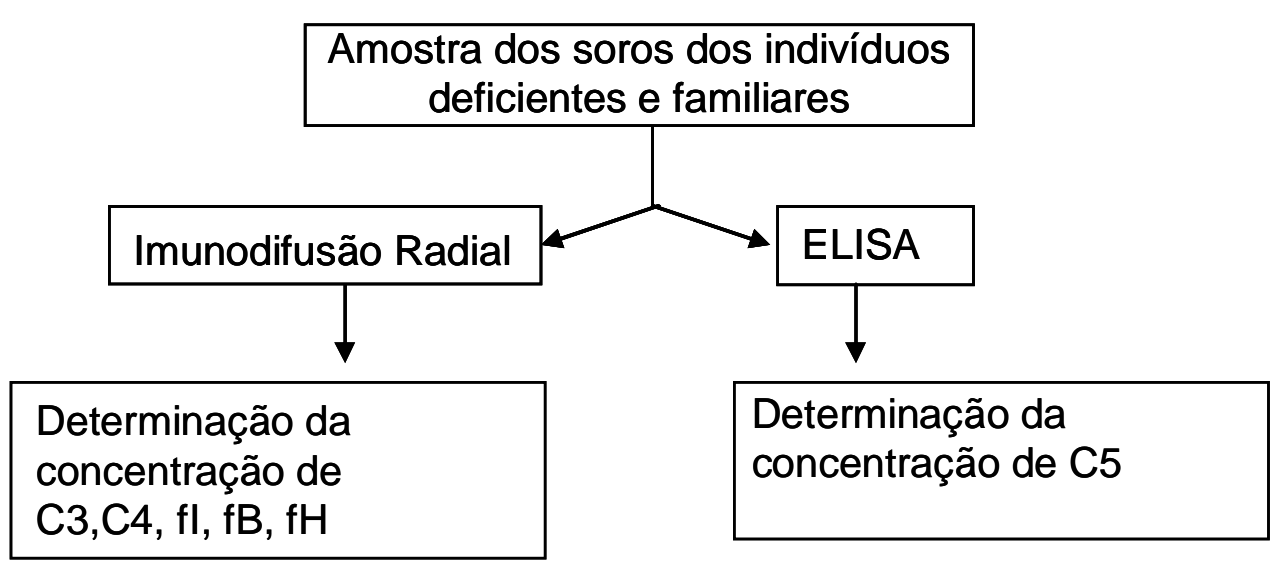


3.14.3 Determinação das possíveis mutações presentes no material genético (DNA genômico e RNA) dos indivíduos avaliados e confirmação da mutação apresentada

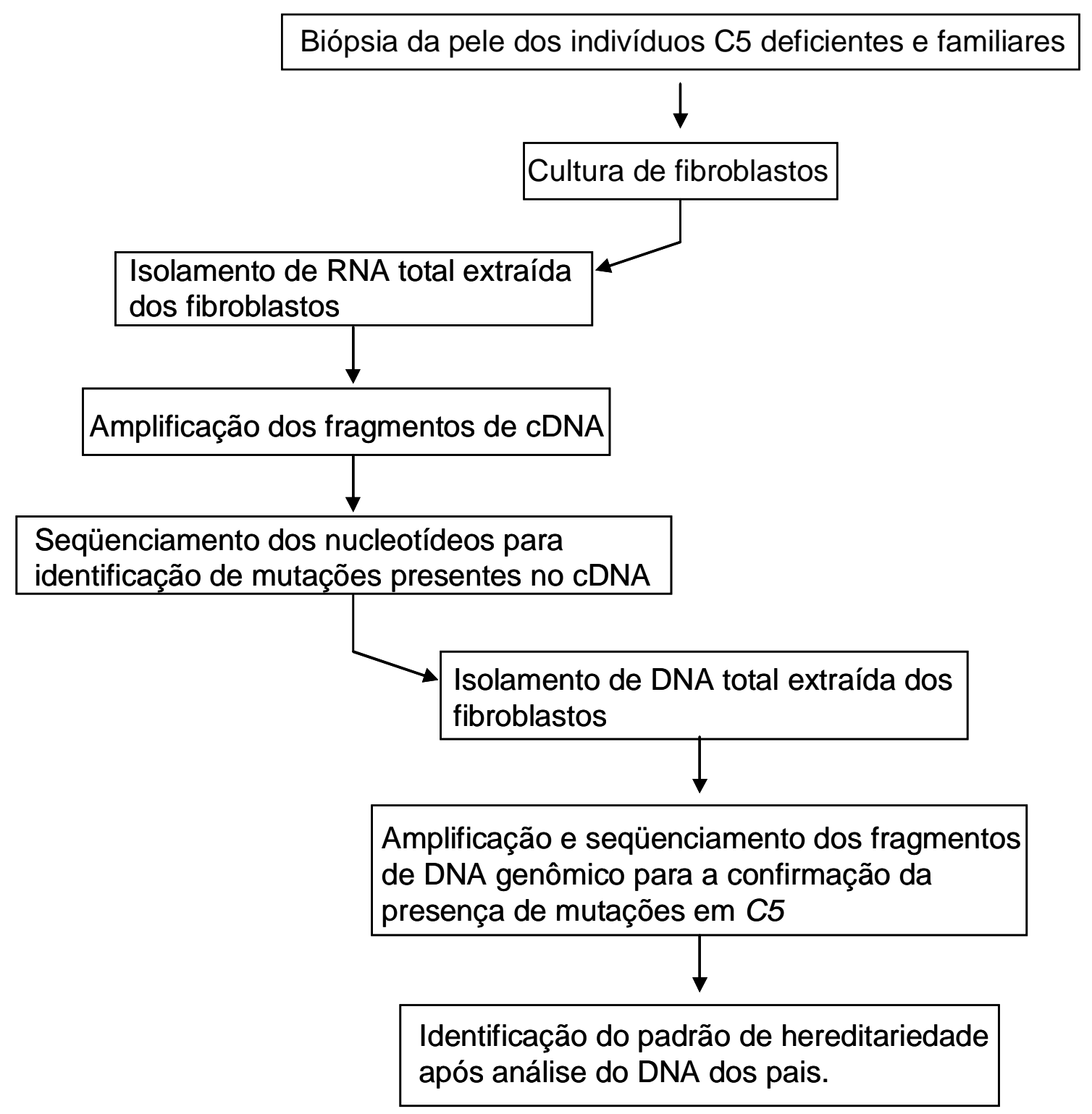




\section{RESULTADOS}

\subsection{Resultados experimentais}

Os indivíduos deficientes de C5 (II:4, II:5 e II:9) provêm de uma família brasileira com história de consangüinidade resultantes de casamento entre primos-irmãos. Vários episódios de meningite e infecções recidivantes foram relatados nesta família, sugestivos de deficiência de proteínas da via terminal comum do sistema complemento. Os indivíduos que sofreram de meningite estão indicados na Figura 12.

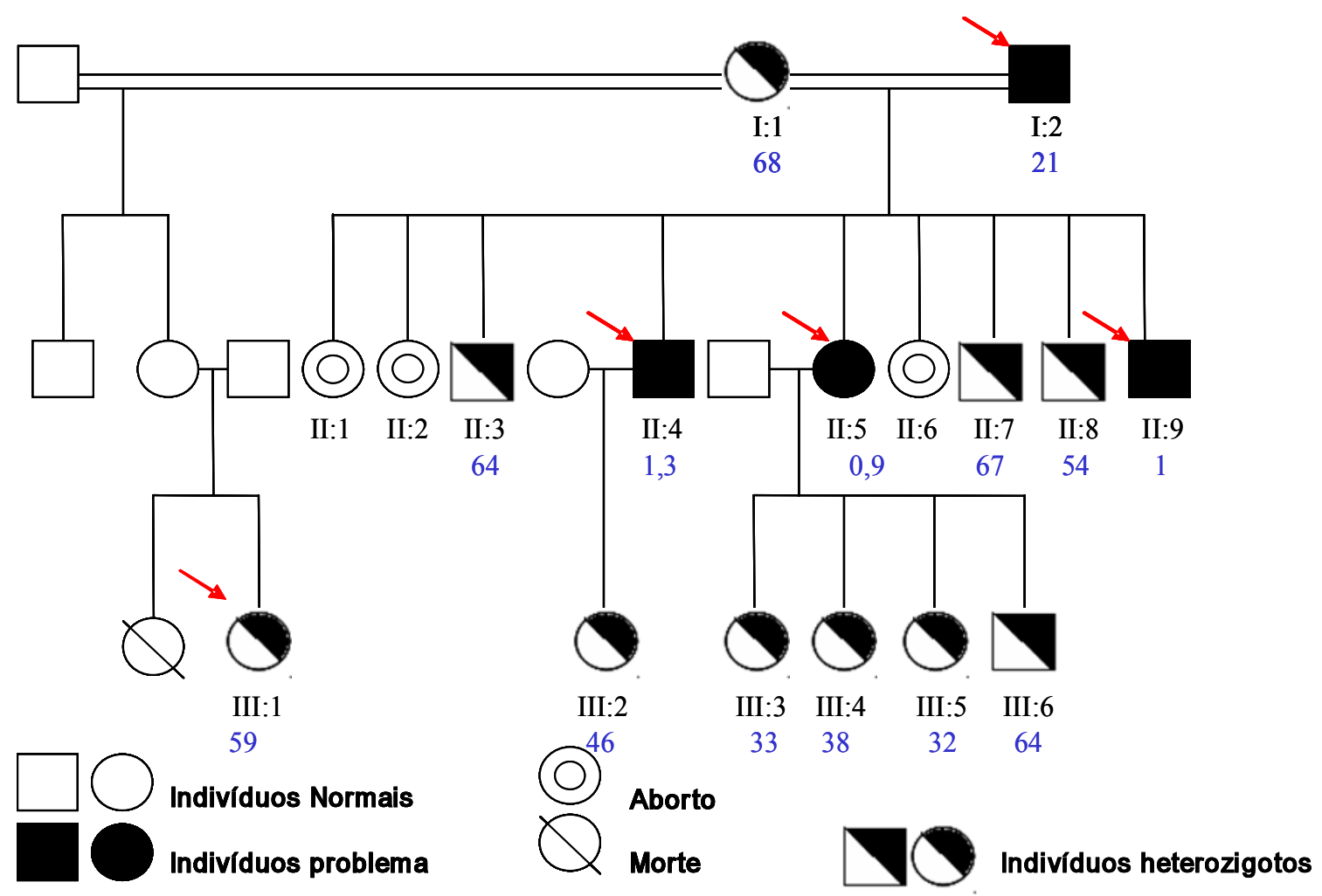

Figura 12. Heredograma da família brasileira deficiente de C5. Os indivíduos deficientes e seus familiares estão representados por números romanos os quais representam a geração à qual pertencem e os números arábicos representam a sua posição na família. A concentração de C5 de cada indivíduo da família está expressada em $\mu \mathrm{g} / \mathrm{ml}$ (côr azul) e a setas vermelhas indicam os indivíduos que tiveram episódios de meningite. 
Ao avaliar a atividade hemolítica desta família (Tabela 9), notamos que nenhum dos soros dos probandos (II:4; II:5 e II:9) foi capaz de apresentar qualquer atividade hemolítica, seja ela mediada pela via clássica ou pela via alternativa.

Tabela 9. Atividade hemolítica mediada pela via clássica e via alternativa dos pacientes deficientes da proteína C5 (II:4, II:5 e II:9) e familiares

\begin{tabular}{|c|c|c|}
\hline & \multicolumn{2}{|c|}{ Atividade Hemolítica } \\
\hline Indivíduos & APH (\%) & CPH (\%) \\
\hline I:1 & 173,3 & 107,0 \\
\hline I:2 & 155,8 & $<25 \%$ \\
\hline II:3 & 170,8 & 94,1 \\
\hline II:4 & sem lise & sem lise \\
\hline II:5 & sem lise & sem lise \\
\hline II:7 & 89,9 & 157,2 \\
\hline II:8 & 92,5 & 102,9 \\
\hline II:9 & sem lise & sem lise \\
\hline III:1 & 141,6 & 108,9 \\
\hline III:2 & 78,4 & 106,2 \\
\hline III:3 & 69,4 & 102,9 \\
\hline III:4 & 52,9 & 93,1 \\
\hline III:5 & 74,2 & 101,2 \\
\hline III:6 & n.a. & 91,3 \\
\hline & & \\
\hline
\end{tabular}

$\mathrm{APH} \%$ e $\mathrm{CPH} \%$ referem- se às porcentagens de hemólise mediadas respectivamente pelas vias alternativa e clássica, considerando- se uma curva padrão determinada com uma mistura de 42 soros de indivíduos normais pura (100\%) ou nas diluições $75 \%, 50 \%$ e $25 \%$. Indivíduo não avaliado (n.a.)

Deve-se ressaltar também que o soro do pai (I:2) apresentou menos de $25 \%$ (limite mínimo do método) da atividade hemolítica mediada pela via clássica e $155,8 \%$ de lise mediada pela via alternativa (Tabela 9). Isto sugere que o soro do pai apresenta concentração reduzida de pelo menos um componente da via clássica (C1q, $\mathrm{C} 1 \mathrm{r}$ ou $\mathrm{C} 2)$, uma vez que as 
concentrações de C1s (dados no mostrados) e de C4 (Tabela 10) são aparentemente normais.

Para inicialmente detectarmos a presença ou ausência de proteínas do complemento (C5, C6, C7, C8 e C9) no soro, utilizamos o método de imunodifusão dupla (OUCHTERLONY, 1978) em gel de agarose empregando anticorpos policlonais anti-C5, anti-C6, anti-C7, anti-C8 ou anti-C9 humanos contra os soros puros e diluídos $(1 / 2 ; 1 / 4 ; 1 / 8$; $1 / 16 ; 1 / 32$ ) dos probandos e seus familiares. Como controle, foi empregada uma mistura de 130 soros de adultos saudáveis. Com esta técnica, não pudemos observar a formação de imunocomplexos quando anti-C5 foi incubado na presença dos soros dos indivíduos II:4, II:5 e II:9 (Figura 13), enquanto as demais proteínas (C6, C7, C8 e C9) encontravam-se presentes em níveis expressivos nos indivíduos avaliados (dados no mostrados).

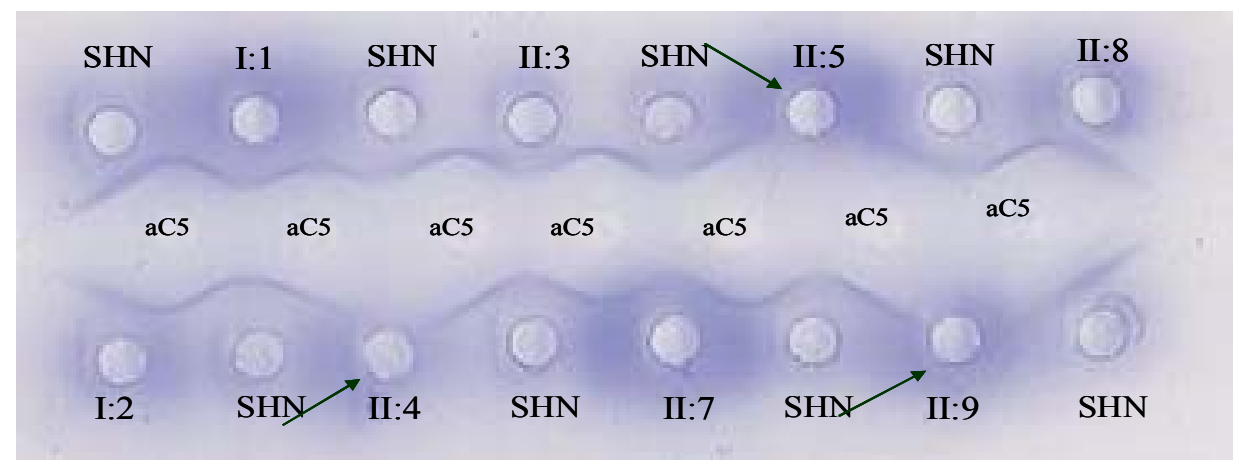

Figura 13. Imunodifusão dupla dos soros dos membros da família deficiente de C5. Os soros dos indivíduos II:4, II:5 e II:9 não formaram halo de precipitação para a proteína C5 (seta verde). SHN: mistura de soros de 130 indivíduos adultos saudáveis. Soros dos indivíduos avaliados foram usados puros e nas diluições: $1 / 2 ; 1 / 4 ; 1 / 8 ; 1 / 16 ; 1 / 32$ (para todos os casos a seta marca o início (puro) e o sentido horário). Anticorpo utilizado, anti-C5, humanos feitos em coelho.

Para determinarmos as concentrações de proteínas do sistema complemento, empregamos a técnica de imunodifusão radial (MANCINI, 1965), mediante esta técnica observamos que as proteínas C3, C4, Fator H e Fator I encontravam-se presentes em concentrações relativamente normais nos soros dos membros avaliados desta família (Tabela 
10). Estes resultados foram comparados com dados já existentes na literatura para indivíduos brasileiros saudáveis (PFARR et al. 2005, FERREIRA DE PAULA et al. 2003 e FERRIANI et al. 1999) e com uma mistura de soros de 42 pessoas saudáveis. Interessante notar que as concentrações séricas de Fator B e da proteína C3 dos pais e filhos (II:3, II:4 e II:5) estão elevadas (Tabela 10) o que explicaria a elevada atividade hemolítica nestes indivíduos mediada pela via alternativa. Em outros integrantes desta família (II:7, II:8, III:2, III:3, III:4, III:5 e III:6) as concentrações do Fator B estão em concentrações reduzidas (140, 183, 150, $125,149,111$ e $134 \mu \mathrm{g} / \mathrm{mL}$ respectivamente), porém dentro ou próximas do intervalo de normalidade para indivíduos de 10- 14 anos de idade $(183-513 \mu \mathrm{g} / \mathrm{mL}$ - FERRIANI et al., 1999). Estes resultados mostrados na Tabela 10 corroboram os resultados mostrados na Tabela 9, onde os pacientes acima mencionados apresentam uma redução da atividade hemolítica mediada pela via alternativa.

A concentração de C5 presente nos soros de todos os indivíduos desta família foi determinada por ELISA. Os soros dos pacientes II:4, II:5 e II:9 apresentaram concentração de C5 de 1,3; 0,9 e 1,0 $\mu \mathrm{g} / \mathrm{ml}$ respectivamente (intervalo de normalidade para adultos brasileiros: 45 - $190 \mu \mathrm{g} / \mathrm{ml}$ - média de 48 indivíduos saudáveis: $91 \mu \mathrm{g} / \mathrm{ml}$ ), o que explica a ausência total da atividade hemolítica mediada pela via clássica e a via alternativa nestes pacientes. Este resultado é compatível com a ausência de C5, uma vez que este componente participa da via terminal comum do sistema complemento. O soro do pai (I:2) apresentou concentrações bastante reduzidas de C5 $(21 \mu \mathrm{g} / \mathrm{ml})$, enquanto a concentração da proteína C5 no soro da mãe $(68,3 \mu \mathrm{g} / \mathrm{ml})$ encontra-se dentro do intervalo de normalidade mencionado acima (Tabela 10), porém abaixo da média de $91 \mu \mathrm{g} / \mathrm{ml}$. Os soros dos irmãos saudáveis dos deficientes: II:3, II:7, II:8 e um dos netos III:6 (filho de II:5) apresentaram 64, 67, 54 e $64 \mu \mathrm{g} / \mathrm{ml}$ de proteína C5 respectivamente. Entretanto, os indivíduos da terceira geração desta família: III:2 (filha do indivíduo deficiente II:4), III:3, III:4 e III:5 (filhos do indivíduo deficiente II:5) apresentaram 
46, 33, 38 e $32 \mu \mathrm{g} / \mathrm{ml}$ da proteína C5 no soro respectivamente, indicativo de um padrão heterozigoto da deficiência de C5.

Tabela 10. Dosagens de proteínas do complemento do soro de pacientes deficientes da proteína C5 (II:4, II:5 e II:9) e familiares.

\begin{tabular}{|l|l|l|l|l|l|l|l|l|l|}
\hline & & & \multicolumn{6}{|l|}{ Proteínas de Complemento } \\
\hline & Sexo & $\begin{array}{l}\text { Idade } \\
(\text { anos })\end{array}$ & Meningites & $\begin{array}{l}\text { C3 } \\
(\mu \mathrm{g} / \mathrm{ml})\end{array}$ & $\begin{array}{l}\text { C4 } \\
(\mu \mathrm{g} / \mathrm{ml})\end{array}$ & $\begin{array}{l}\text { C5 } \\
(\mu \mathrm{g} / \mathrm{ml})\end{array}$ & $\begin{array}{l}\text { Fator H } \\
(\mu \mathrm{g} / \mathrm{ml})\end{array}$ & $\begin{array}{l}\text { Fator I } \\
(\mu \mathrm{g} / \mathrm{ml})\end{array}$ & $\begin{array}{l}\text { Fator B } \\
(\mu \mathrm{ml})\end{array}$ \\
\hline I:1 & F & 60 & Não & 3235 & 677 & 68 & 615 & 58 & 373 \\
\hline I:2 & $\mathbf{M}$ & $\mathbf{6 2}$ & Sim & $\mathbf{2 1 4 2}$ & $\mathbf{7 8 2}$ & $\mathbf{2 1}$ & $\mathbf{5 8 8}$ & $\mathbf{7 0}$ & $\mathbf{3 1 3}$ \\
\hline II:3 & M & & Não & 1632 & 850 & 64 & 481 & 53 & 325 \\
\hline II:4 & $\mathbf{M}$ & $\mathbf{3 3}$ & Sim & $\mathbf{1 8 7 9}$ & $\mathbf{5 1 1}$ & $\mathbf{1 , 3}$ & $\mathbf{5 3 4}$ & $\mathbf{6 0}$ & $\mathbf{3 9 1}$ \\
\hline II:5 & $\mathbf{F}$ & $\mathbf{3 2}$ & Sim & $\mathbf{2 2 3 2}$ & $\mathbf{6 2 6}$ & $\mathbf{0 , 9}$ & $\mathbf{4 8 1}$ & $\mathbf{6 2}$ & $\mathbf{3 6 0}$ \\
\hline II:7 & M & 25 & Não & 680 & 396 & 67 & 480 & n.a. & 140 \\
\hline II:8 & M & 22 & Não & 1343 & 478 & 54 & 756 & n.a. & 183 \\
\hline II:9 & $\mathbf{M}$ & $\mathbf{1 6}$ & Sim & $\mathbf{1 7 9 5}$ & $\mathbf{2 8 4}$ & $\mathbf{1 , 0}$ & $\mathbf{4 3 8}$ & $\mathbf{4 8}$ & $\mathbf{2 2 7}$ \\
\hline III:1 & F & 19 & Sim & 2553 & 568 & 59 & 434 & 50 & 259 \\
\hline III:2 & F & & Não & 1249 & 219 & 46 & 423 & n.a. & 150 \\
\hline III:3 & F & 13 & Não & 1498 & 520 & 33 & 482 & n.a. & 125 \\
\hline III:4 & F & 11 & Não & 1511 & 679 & 38 & 482 & n.a. & 149 \\
\hline III:5 & F & 10 & Não & 978 & 706 & 32 & 756 & n.a. & 111 \\
\hline III:6 & M & 8 & Não & 1406 & 396 & 64 & 756 & n.a. & 134 \\
\hline Valores & & (6-13 anos $)$ & $540-1470$ & $99-338$ & & $225-1636$ & $34-91$ & $185-513 *$ \\
Normais & & $($ adulto $)$ & $1000-1500$ & $450-600$ & $45-190$ & $242-759$ & $39-100$ & $200-210$ \\
\hline
\end{tabular}

Indivíduo não avaliado (n.a.). Intervalo de normalidade das proteínas de complemento encontrase em $\mu \mathrm{g} / \mathrm{ml}$. A concentração de C5 presente nos soros de todos os indivíduos desta família foi determinada por ELISA (valores normais para adultos brasileiros: 45 - $190 \mu \mathrm{g} / \mathrm{ml}$ - média de 48 indivíduos saudáveis: $91 \mu \mathrm{g} / \mathrm{ml}$ ) Indivíduos deficientes de C5 são mostrados em negrita. A concentração da proteína C3, C4, Fator B, Fator I e Fator $\mathrm{H}$ foram determinadas por imunodifusão radial. Referências citadas para os valores normais de: Fator I e Fator H (FERREIRA DE PAULA et al. 2003); e C3, C4 e Fator B (FERRIANI et al. 1999). *Estes valores correspondem ao intervalo de normalidade para soros de indivíduos de 10 a 14 anos de idade 
Para confirmar que a falta de atividade hemolítica é causada unicamente pela falta de proteína C5 no soro, decidimos avaliar a via alternativa no probando II:9 após adição de diferentes concentrações de C5 purificado (266, 133, 66 e 33 ng/ $\mu 1$ - Tabela 11). Notamos que à medida que aumentávamos a concentração de C5 também aumentava proporcionalmente a atividade hemolítica do soro C5D. Este resultado indica que das proteínas do sistema complemento que participam da via alternativa apenas o componente $\mathrm{C} 5$ está ausente no soro do paciente II:9.

Tabela 11. Atividade hemolítica do soro do probando II:9, após reposição com proteína C5 humana purificada.

\begin{tabular}{|l|l|l|}
\hline & $\begin{array}{l}\text { Concentração final de C5 } \\
\text { em } \mathrm{ng} / \mu \mathrm{l}\end{array}$ & $\begin{array}{l}\text { Atividade Hemolítica } \\
\text { APH (\%) }\end{array}$ \\
\hline Soro II:9 & 266 & 105,9 \\
\hline Soro II:9 & 133 & 86,8 \\
\hline Soro II:9 & 66 & 82,2 \\
\hline Soro II:9 & 33 & sem lise \\
\hline Soro II:9 & 0 & sem lise \\
\hline
\end{tabular}

Concentração da proteína C5 no soro normal: 45 - $190 \mu \mathrm{g} / \mathrm{ml}$ (intervalo de normalidade para adultos brasileiros: 45 - $190 \mu \mathrm{g} / \mathrm{ml}$ - média de 48 indivíduos saudáveis: $91 \mu \mathrm{g} / \mathrm{ml}$ )

$\mathrm{Na}$ etapa seguinte, decidimos investigar quais alterações genéticas poderiam explicar a ausência deste componente do sistema complemento. Para abordar esta questão, cultivamos fibroblastos a partir de biópsias de pele de indivíduos normais e dos probandos para servirem como fonte de DNA e RNA. Empregamos PCR e RT-PCR para investigar a presença de mutações no gene C5 e RNAm de C5 nestes deficientes. 
As regiões do gene $C 5$ foram amplificadas a partir do DNA genômico (Figura 14) e do cDNA (Figura 15) dos indivíduos deficientes de C5 (II:4 e II:9) e seus familiares (I:1 e I:2) e comparadas com o controle normal (fibroblasto humano normal - FHN). Devido à dificultade para amplificar a região correspondente ao éxon 1 do cDNA de C5, decidimos amplificar os íntrons próximos ao éxon 1 do DNA genômico, mas não encontramos qualquer mutação (Figura 14) na região correspondente ao éxon 1 nos indivíduos avaliados (I:1, I:2 e II:9).

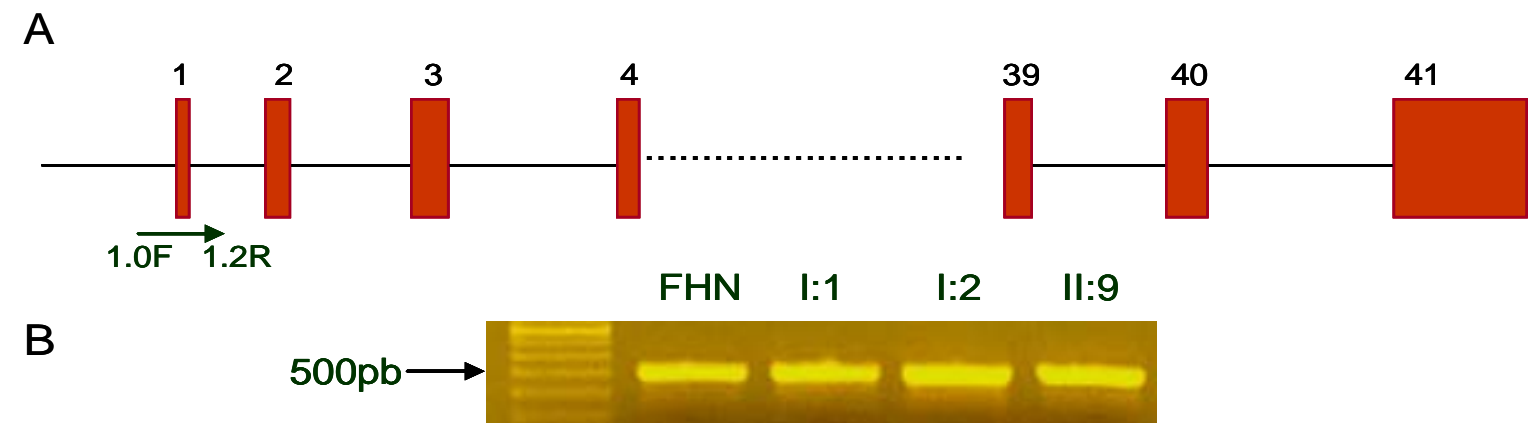

Figura 14. Amplificação do DNA genômico da região que abrange o éxon 1. (A) Estrutura do gene C5. (B) Amplificação do éxon 1 incluindo os íntrons próximos. No seqüenciamento não se observou a presença de qualquer mutação nos indivíduos avaliados.

Conforme mostrado na Figura 15 (A) o gene C5 contem 41 éxons, com tamanhos variando de 61 pb (éxon 16) a 531 pb (éxon 41). Na Figura 15 (A) encontra-se a distribuição dos oligonucleotídeos usados na etapa de amplificação 45F-587R (542 pb); 64F- 587R (523 pb); 102F-1380R (1278 pb); 1321F-2710R (1389 pb); 2700F-4050R (1350 pb) e 4021F5436R (1415 pb). Na Figura 11 encontra-se a amplificação destas regiões em fibroblastos de indivíduos normais para complemento. 
Constatamos que os produtos amplificados no cDNA de $\mathrm{C} 5$, correspondentes aos fragmentos localizados entre $45-587$ pb; 102-1380 pb; 1321-2710 pb; 2281-3421 pb e 40215436 pb não apresentaram qualquer deleção visível (Figura 15) em todos os indivíduos avaliados. A região compreendida entre os nucleotídeos 45-587 (542 pb) apresenta dois transcritos de 800 pb e 700 pb (descritos anteriormente por CARNEY et al., 1991). A região comprendida entre os nucleotídeos 3210 - 4050 pb (840 pb), apresenta uma deleção de 150 pb presente em todos os indivíduos deficientes de C5 avaliados (I:1, I:2, II:4 e II:9). A mãe (I:2) apresentou um padrão heterozigoto, amplificando pelo menos dois produtos: um de 840 $\mathrm{pb}$ (produto expressado no indivíduo normal) e um produto de $\sim 650 \mathrm{pb}$ (produto presente nos indivíduos deficientes de C5). Resaltamos que a banda de maiorr tamanho é de natureza inespecífica, confirmada após seqüenciamento. 
A

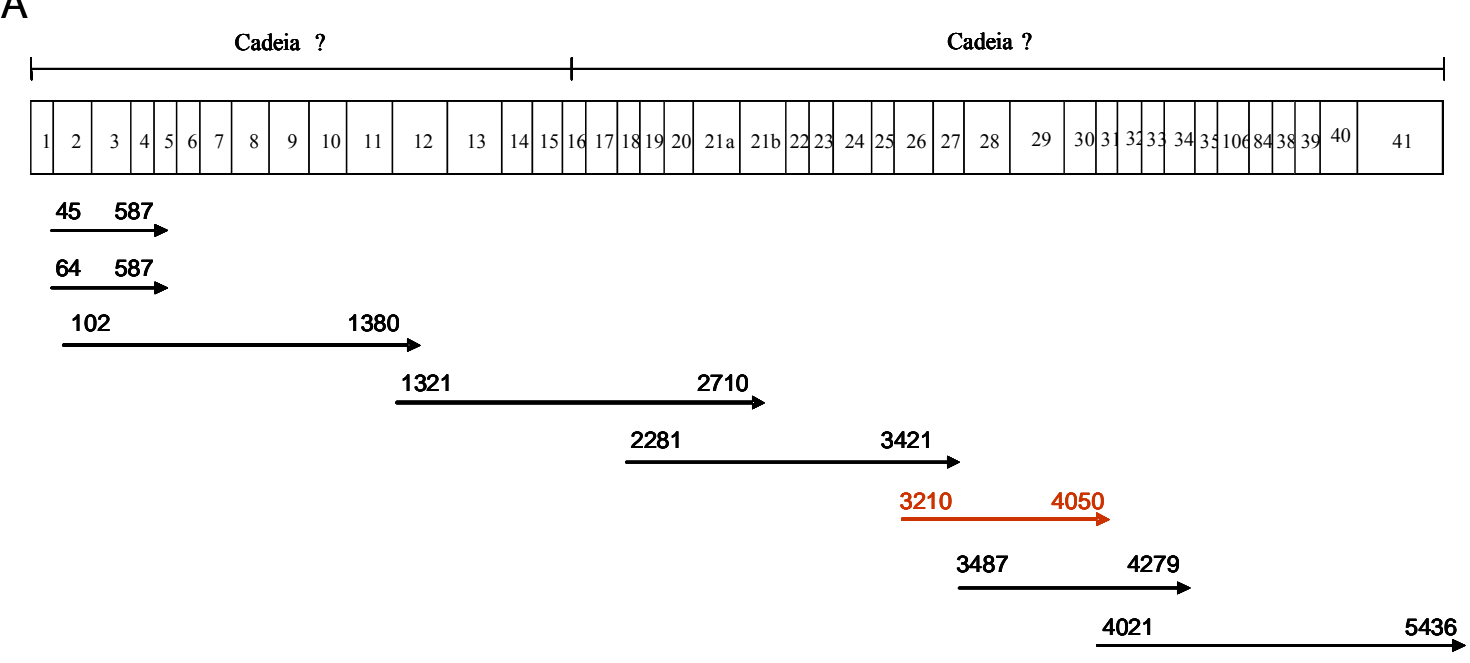

B

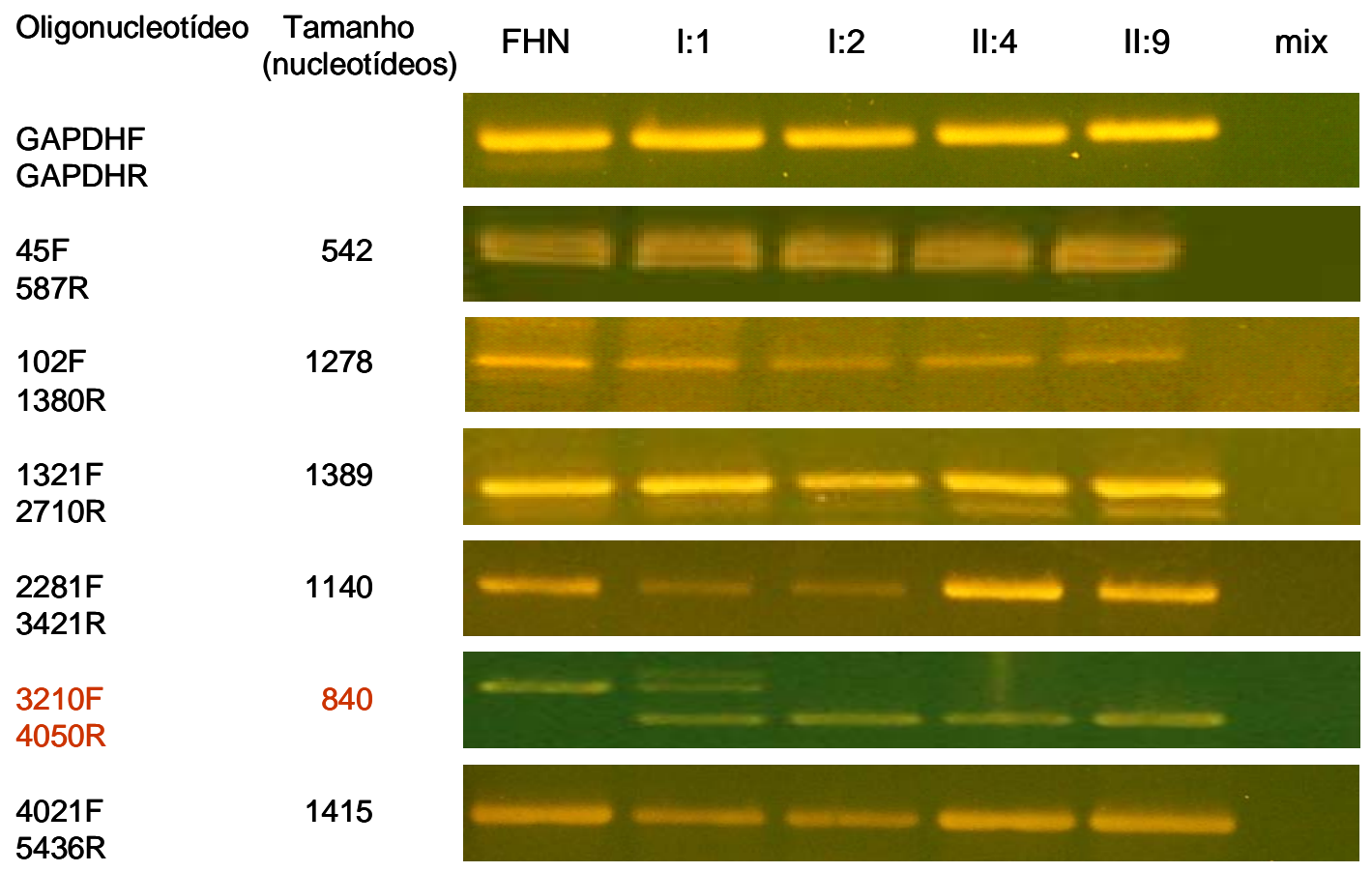

Figura 15. Avaliação comparativa dos produtos amplificados do cDNA de C5 de vários membros desta família. (A) Esquema que representa o cDNA C5 (CARNEY, et. al., 1991), incluindo os oligonucleotídeos utilizados. (B) Amplificação destes produtos em vários membros da família. Observa-se uma deleção de 150 nucleotídeos nestes indivíduos (em vermelho). FHN: fibroblastos de humano normal. GAPDH: controle positivo. Os tamanhos dos produtos indicados à esquerda da figura referem-se aos tamanhos esperados em indivíduos normais. I:1: mãe; I:2: pai; II:4 e II:9: pacientes deficientes. Mix: controle técnico. 
A análise do seqüenciamento do gene $C 5$ do paciente II:9 revelou uma substituição $\mathrm{C}^{498}$ por uma $\mathrm{T}^{498}$ (Figura 16), sendo que na etapa de tradução ambos os códons (ACC e ACT) geram o aminoácido Thr, portanto esta substituição deve ser considerada como uma mutação silenciosa.

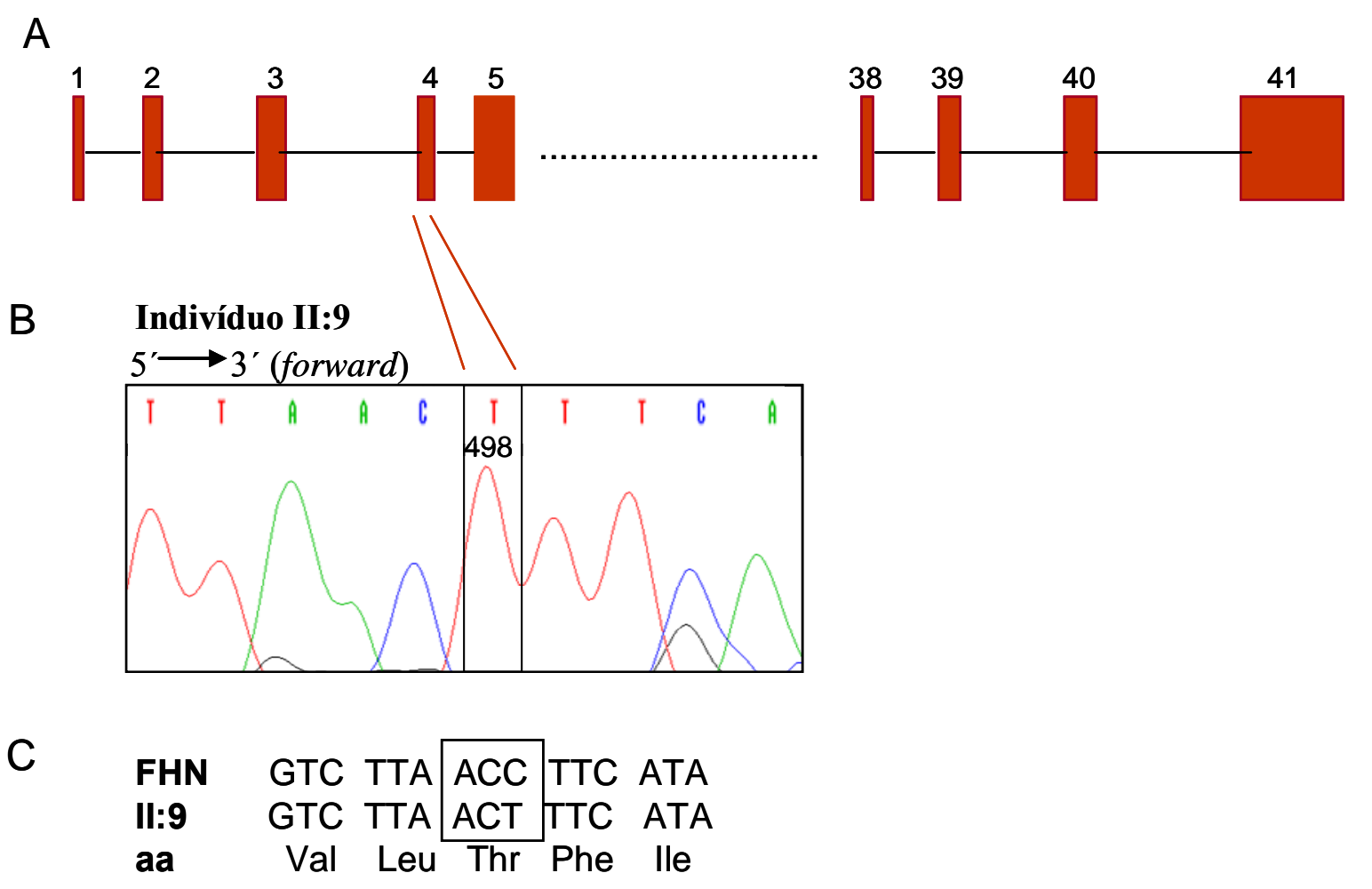

Figura 16. Seqüenciamento do éxon 4 do paciente II:9. (A) DNA genômico C5. (B) Cromatograma do éxon 4. (C) Seqüenciamento mostrando a substituição de um ACC ${ }^{498}$ por um $\mathrm{ACT}^{498}$ (fita 5'-3') no éxon do indivíduo II:9 (C5D).

Os indivíduos I:1, I:2, II:4 e II:9 apresentaram uma deleção de 153 nucleotídeos (Figura 17) que corresponde ao éxon $30 \mathrm{em}$ sua totalidade, esta deleção inicia-se no nucleotídeo $G^{3876}$ e culmina no nucleotídeo $G^{4029}$. O experimento foi feito em duplicata no sentido forward e reverso 
A

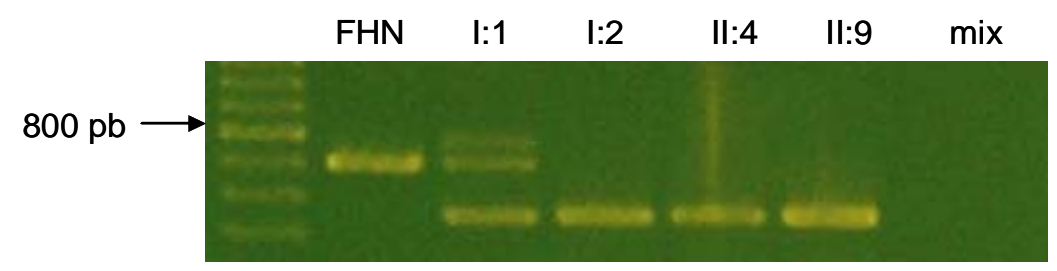

B

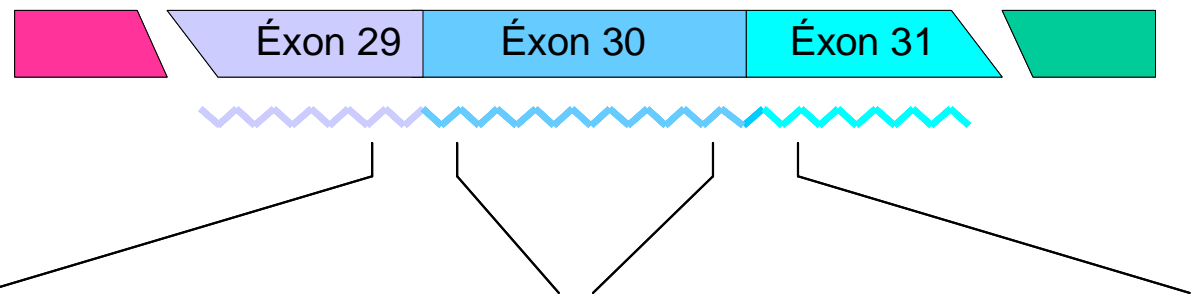

FHN:

TTATTCAACCCAGGACACCATCAAT....GAGGCCAGTAGAGGTGCTTCTCAATG Indivíduos C5D: TTATTCAACCCAG ${ }^{3876}$

${ }^{4030} \mathrm{GTGCTTCTCAATG}$

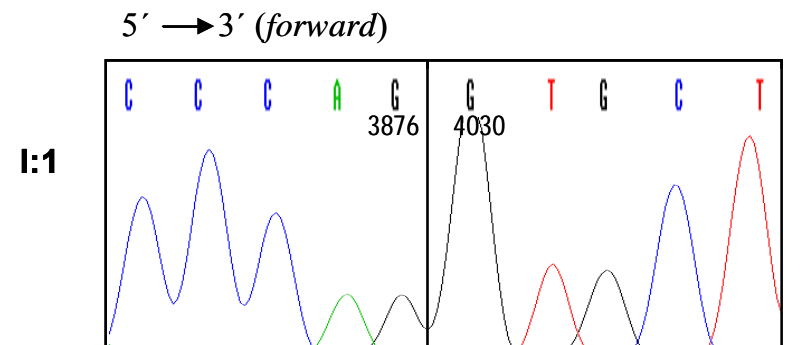
$5^{\prime} \rightarrow 3^{\prime}$ (reverse)
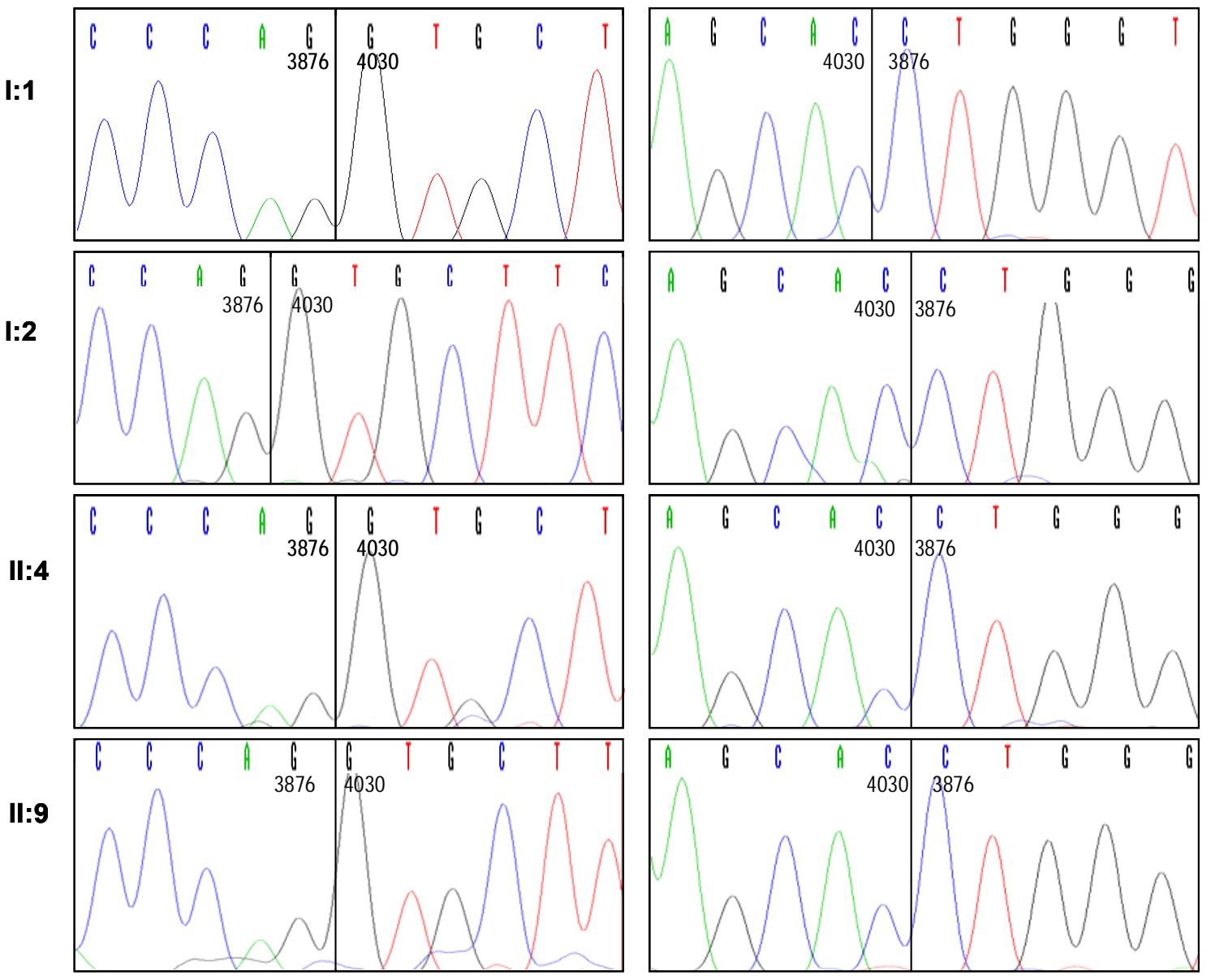

Figura 17. Seqüenciamento dos éxons 29,30 e 31 do cDNA de $C 5$ dos indivíduos I:1, I:2, II:4 e II:9 e os respectivos cromatogramas. (A) Amplificação do cDNA (nucleotídeos 3487 4249) mostra uma deleção de 153 nucleotídeos. O indivíduo I:1 (mãe) é heterozigoto e apresenta os dois produtos amplificados: o normal (762 pb) e sem o éxon 30 (609 pb). (B) cDNA de C5 mostrando do éxon 29 ao éxon 31. (C) O seqüenciamento e seu respectivo cromatograma da região mostrada em B mostra a deleção do éxon 30 em sua totalidade. FHN: fibroblasto humano normal; I:1: mãe; I:2: pai; II:4 e II:9: pacientes deficientes 
Para avaliar se estes indivíduos possuem um defeito de splicing no éxon 30 ou se carecem deste éxon no gene C5 decidimos avaliar do éxon 29 ao éxon 31 incluindo os íntrons próximos a eles, quando encontramos após amplificação que todos os indivíduos avaliados possuem a região intrônica (Figura 18). Portanto, a causa desta deficiência é um erro no “splicing” do RNAm de C5 nos indivíduos afetados.

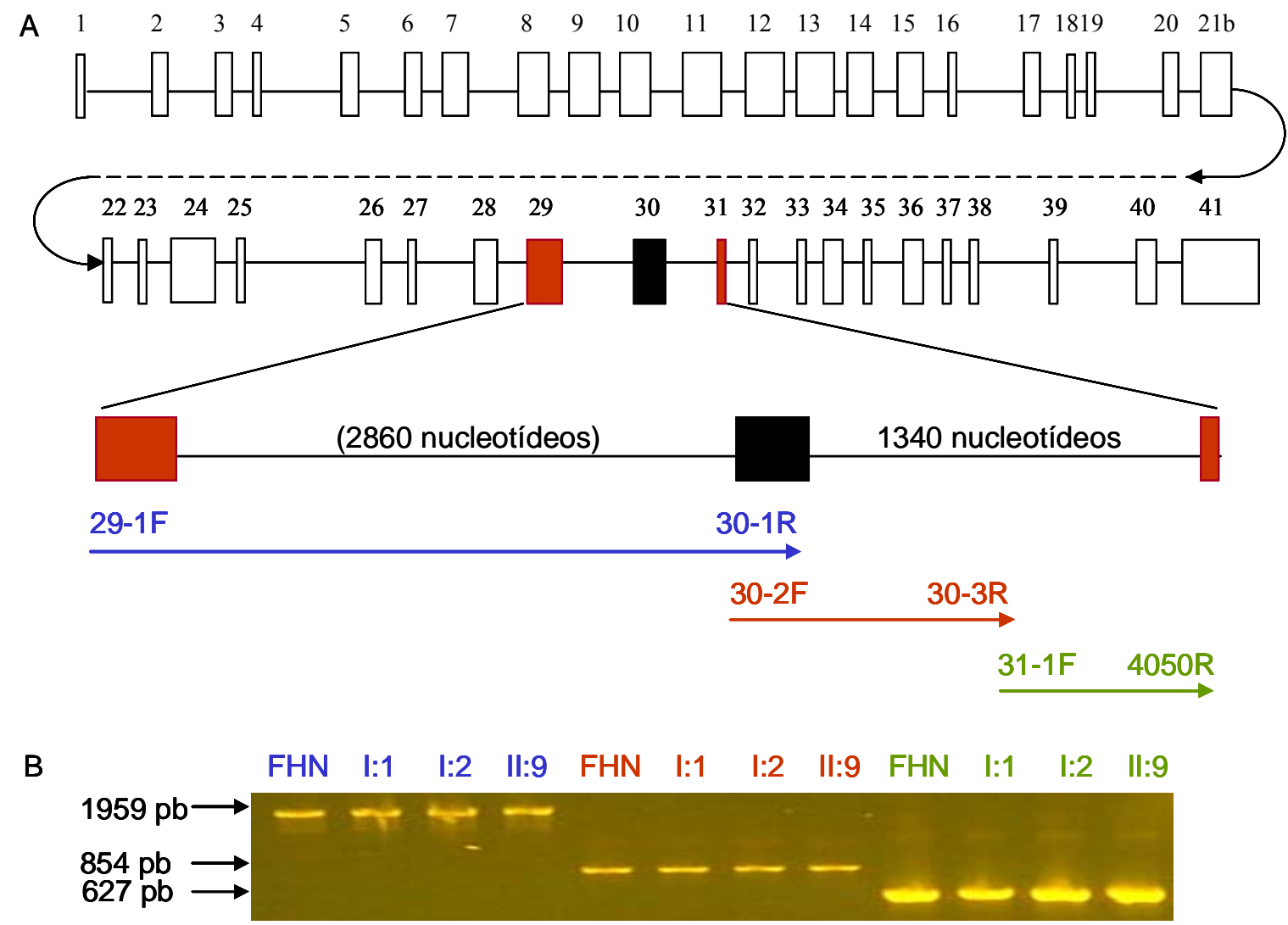

Figura 18. Amplificação da região comprendida entre o éxon 29 ao éxon 31, incluindo os íntrons próximos do DNA genômico dos indivíduos I:1, I:2 e II:9. (A) Estrutura do gene C5. (B) Todos os indivíduos avaliados pertencentes à família deficiente de C5 apresentam a região intrônica correspondente ao éxon 29 e 30. FHN: fibroblasto humano normal; I:1: mãe; I:2: pai e II:9: pacientes deficientes 
A partir do seqüenciamento destas regiões no gene $C 5$ encontramos a substituição de uma GAG por uma GAA na posição 31058262 (Figura 19), correspondente ao último nucleotídeo do éxon 30 no cDNA dos indivíduos I:1, I:2 e II:9. O seqüenciamento dos nucleotídeos do indivíduo I:1 confirma o padrão heterozigoto. Na Figura 20 se mostra outra substituição na região intrônica entre o éxon 30 e o éxon 31 de C por G na posição 31055723. O indivíduo I:1 apresenta um padrão heterozigoto. 

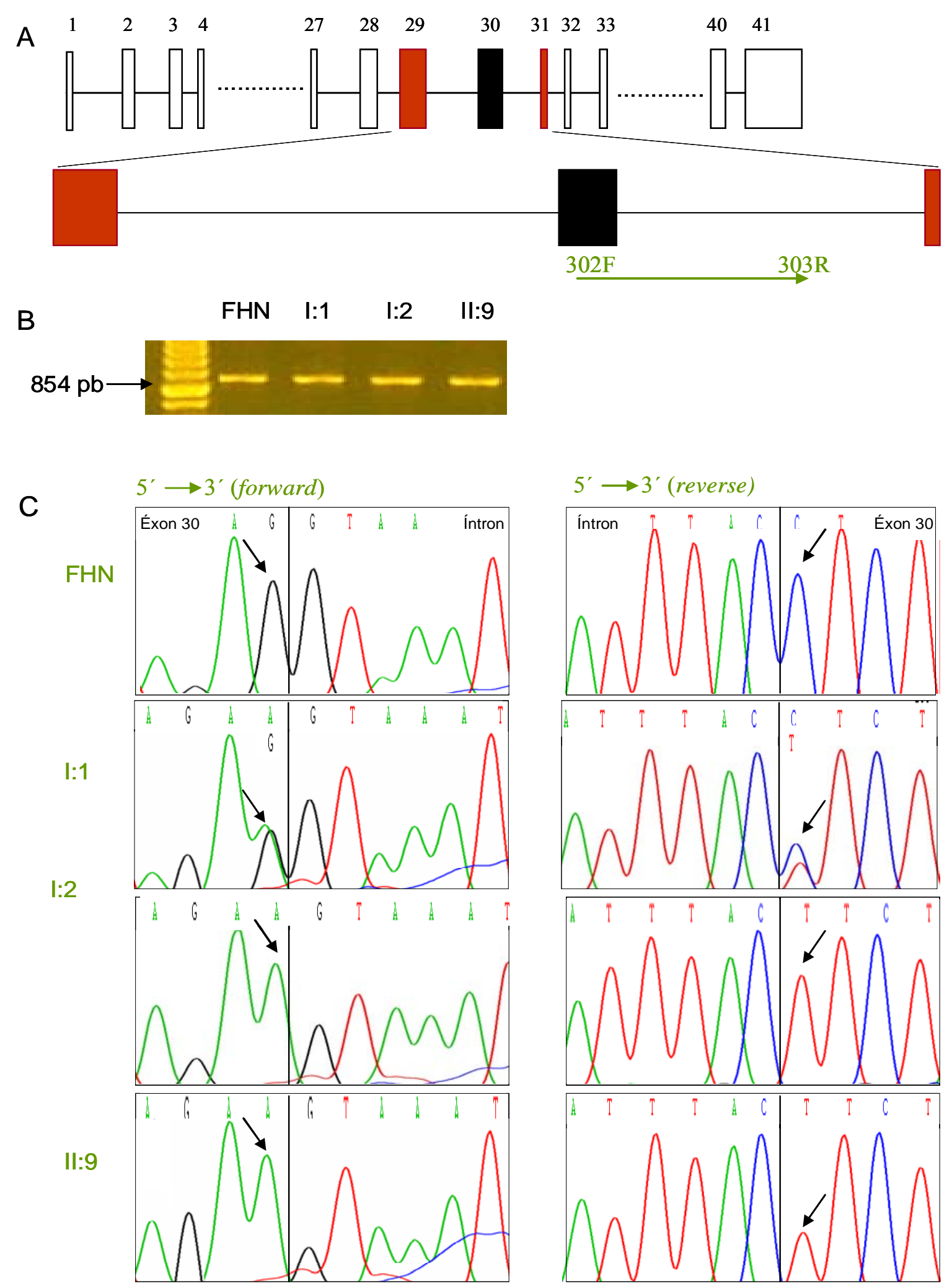

Figura 19. Seqüenciamento do éxon 30 e seu respectivo íntron nos indivíduos I:1, I:2 e II:9. (A) Estrutura do gene C5. (B) Amplificação do éxon 30 e seus íntrons próximos. (C) Cromatograma do éxon 30. Observa-se uma substituição de G por A (posição 31058262) do último nucleotídeo do éxon 30 no gene $C 5$ (seta preta). O indivíduo I:1 apresenta um padrão heterozigoto. FHN: fibroblasto humano normal; I:1: mãe; I:2: pai; II:4 e II:9: pacientes deficientes 

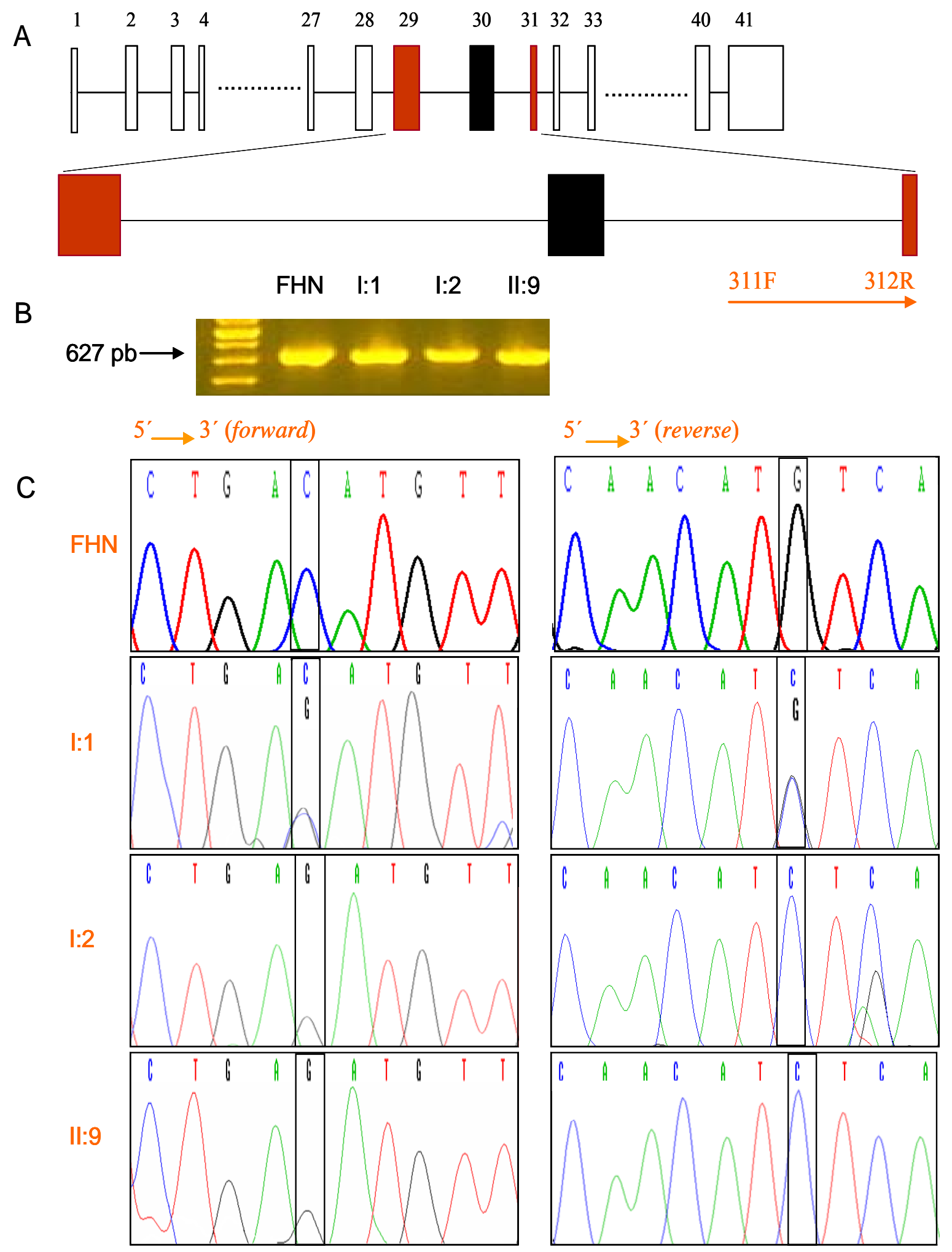

Figura 20. Seqüenciamento do íntron 30 e o éxon 31 do gene $C 5$ dos indivíduos I:1, I:2 e II:9. (A) Estrutura do gene C5. (B) Amplificação do produto correspondente ao íntron 30 e éxon 31. (C) Seqüenciamento e correspondente cromatograma. Nos indivíduos I:2 e II:9 se observa na região intrônica entre o éxon 30 e o éxon 31 a substituição de $\mathrm{C}$ por $\mathrm{G}$ na posição 31055723. O indivíduo I:1 apresenta um padrão heterozigoto. FHN: fibroblasto humano normal; I:1: mãe; I:2: pai; II:4 e II:9: pacientes deficientes 


\subsection{Fluxograma dos resultados}

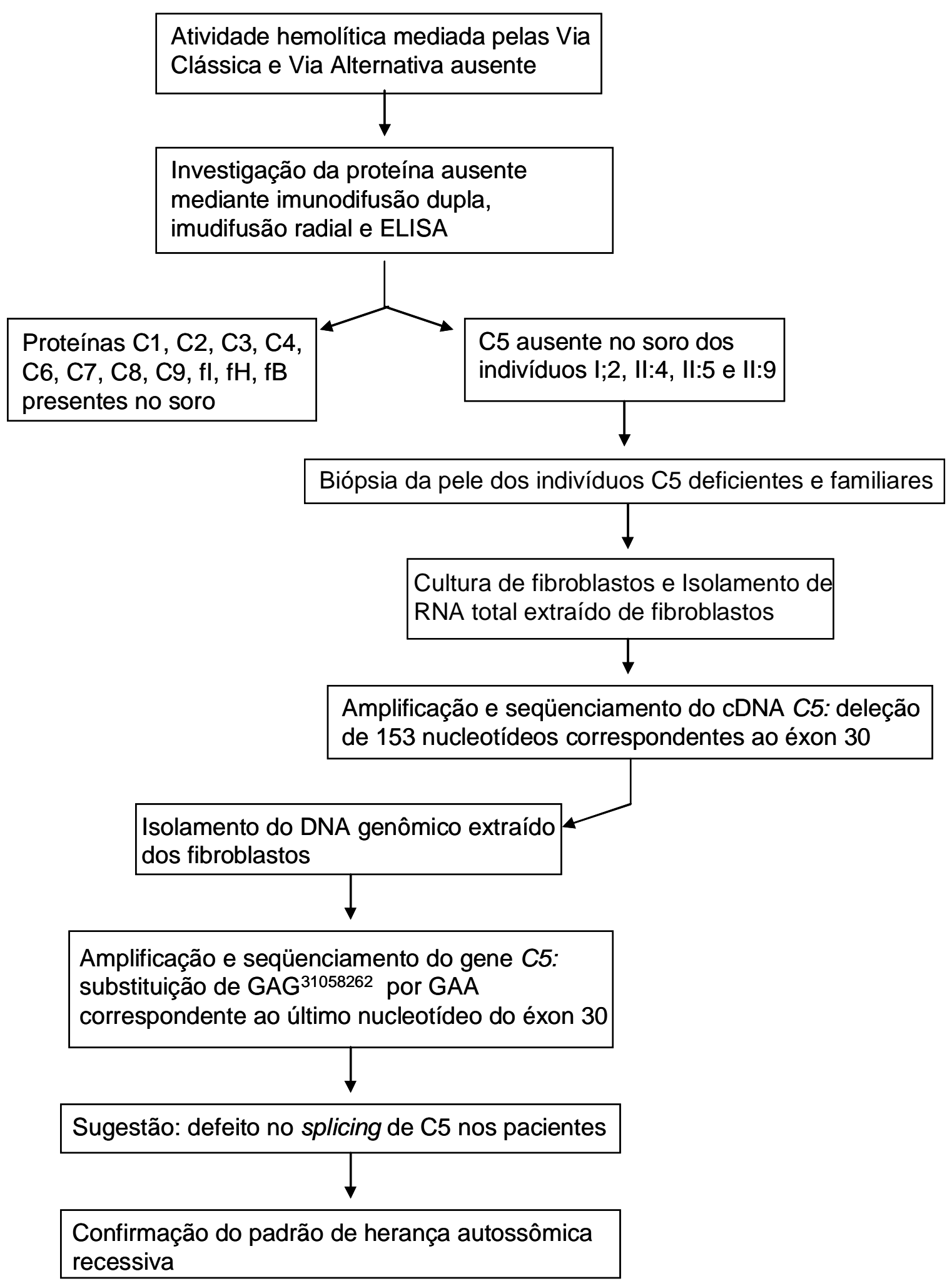




\section{DISCUSSÃO}

A deficiência da proteína C5 (C5D) é rara e até hoje 38 casos distribuídos em 21 famílias foram relatados na literatura, dos quais quinze são homens e vinte três mulheres. Esta deficiência não é exclusiva a uma raça em particular, caucasianos (espanhóis, escandinavos, franceses, suíços, alemães, marroquinos e por último paquistaneses e turcos) e afro-americanos podem ser C5D (Tabela 8).

Neste estudo, três (II:4, II:5 e II:9) de nove irmãos de uma família brasileira com história de consangüinidade apresentaram vários episódios de meningite e infecções repetitivas, o que sugere a possibilidade de se tratar de deficiência de alguma das proteínas da via terminal comum do sistema complemento. ROSENFELD et al. (1976); HAENEY et al. (1980); AYENSA et al. (1985); CESBRON et al. (1985); GIANELLA-BORRADORI et al. (1990); ASGHAR et al. (1991); SANAL et al. (1992); BOLS et al. (1993); SCHOONBROOD et al. (1995); DELGADO-CERVIÑO et al. (2005) e PFARR et al. (2005) já haviam demonstrado que indivíduos deficientes de alguma proteína da via terminal comum falhavam na indução da atividade hemolítica mediada pela via clássica e pela via alternativa.

Indivíduos deficientes de alguma proteína pertencente à via terminal comum do sistema complemento geralmente apresentam uma forte tendência a adquirir infecções piogênicas ocasionadas por bactéria do gênero Neisseria (Tabela 5). Em nosso estudo, cinco integrantes (I:2, II:4, II:5, II:9 e III:1) pertencentes a uma família com histórico de consangüinidade sofreram de muitos episódios meningite. O probando II:9 apresentou meningite em três ocasiões: aos três meses, aos nove meses de idade (internado por 13 dias) e a os onze anos de idade (internado por 11 dias). Os outros quatro pacientes também sofreram de meningites em diversas ocasiões.

Para saber as causas dos ataques de meningites nestes pacientes, decidimos por avaliar a atividade hemolítica mediado pelo sistema complemento em esta família. Os soros dos 
pacientes II:4, II:5 e II:9 não foram capazes de ativar nenhuma das duas vias do sistema complemento (via clássica e a via alternativa). O indivíduo I:2 só apresentou 25\% de hemólise na ativação mediada pela via clássica em quanto que a ativação mediada pela via alternativa foi normal. O indivíduo III:1 apresenta uma boa ativação do sistema complemento apesar de haver tido meningite em uma ocasião (APH: 141,6 e CPH: 108,9\%), sugerindo que quadro de meningites pode haver-se desenvolvido por outras causas não relacionadas ao sistema complemento.

Para saber que proteína da via terminal comum esta faltando, decidimos pela técnica de imunodifusão dupla, observando que as proteínas (C5, C6, C7, C8 e C9) encontram-se presentes em níveis expressivos em todos os membros da família, com exceção dos indivíduos II:4, II:5 e II:9 que não expressam C5 no soro.

SNYDERMAN et al. (1979); HAENEY et al. (1980); PETER et al. (1981); CESBRON et al. (1985); HILDENHAGEN \& BITTER-SUERMANN (1985); NIELSEN \& KOCH (1987); ROSEN et al. (1988); FIJEN et al. (1989); GIANELLA-BORRADORI et al. (1990); SANAL et al. 1992; BOLS et al. (1993); CHAUDHURI et al. (1994); PFARR et al. (2005); DELGADO CERVIÑO et al. (2005) encontraram que os pacientes C5D apresentavam maior suscetibilidade a infecções respiratórias, infecções na pele, otites, febre e vômito, além das infecções redicivantes graves causadas por bactérias do gênero Neisseria, incluindo Neisseria meningitidis e Neisseria gonorreia. Confirmando este achado o paciente II:9 apresentou também um episódio de otite e infecções por pneumococos.

Em alguns casos, esta deficiência está associada a outros sinais clínicos. ASGHAR et al. (1991) avaliaram uma paciente de 29 anos C5D que apresentava alopecia, hipopigmentação no couro cabeludo, crostas e eritema. Após análise histopatológica, observou-se atrofia da epiderme e lâmina basal, acompanhada por desenvolvimento de lúpus eritematoso discoidal. Em outro trabalho, SCOONBROOD et al. (1995) relataram um 
indivíduo homozigoto $\mathrm{C} 5 \mathrm{D}$ que apresentava anti-SSA, (anticorpos específicos para a síndrome primária de Sjögren), mas, como no caso anterior, faltam muitos estudos para esclarecer se esta associação é casual ou não.

O grupo de pesquisa de GIANELLA-BORRADORI et al. (1990) mostrou pela primeira vez a deficiência completa de C5 combinada com deficiência parcial de C4 em uma família suíça. Os soros destes irmãos não apresentaram atividade dependente da via clássica ou da via alternativa, mas ao adicionarem C5 purificado, a atividade mediada pela via alternativa foi completamente restaurada.

$\mathrm{Na}$ avaliação das outras proteínas do sistema complemento, encontramos que as proteínas C4, Fator H e Fator I estão presentes em concentrações relativamente normais nos soros dos indivíduos avaliados desta família, com exceção do probando II:9 e do familiar III:2 que, comparando com o resto da família, apresentam concentrações reduzidas do componente C4: 284 e $219 \mu \mathrm{g} / \mathrm{mL}$ respectivamente (limite de normalidade 450-600 $\mu \mathrm{g} / \mathrm{mL}$ - FERRIANI et al. 1999). Mesmo quando esta baixa concentração de C4 foi encontrada no indivíduo III:2 (129 $\mu \mathrm{g} / \mathrm{mL})$, ela foi suficiente para induzir uma adequada atividade hemolítica mediada pela via clássica (porcentagem de lise: 106,2).

As concentrações de Fator B nos indivíduos (II:7, II:8, III:2, III:3, III:4, III:5 e III:6) estão em concentrações reduzidas: 140, 183, 150, 125, 149, 111 e $134 \mu \mathrm{g} / \mathrm{mL}$ respectivamente (intervalo de normalidade em adultos 200-210 $\mu \mathrm{g} / \mathrm{mL}$ e em crianças- $185-513 \mu \mathrm{g} / \mathrm{mL}$ FERRIANI et al., 1999) o que poderia explicar a baixa atividade hemolítica mediada pela via alternativa nestes pacientes foi de $89,9 \% ; 92,5 \% ; 78,4 \% ; 69,4 \% ; 52,9 \%$ e $74,2 \%$ respectivamente, o indivíduo III:6 não foi avaliado (intervalo de normalidade ao rango de 95\% para a ativação da via alternativa é de 71-171\%). Estudos futuros deverão ser feitos para melhor definir se estes pacientes apresentam deficiência parcial de Fator B. Uma possibilidade a ser considerada é que esta diminuição na concentração desta proteína deve-se 
a uma condição de heterozigose em um dos alelos do Fator B que precisaria ainda ser confirmada.

A técnica de imunodifusão radial serve para determinar a concentração de proteínas que se encontram em grandes quantidades no soro. Não podemos determinar a concentração da proteína C5 por esta técnica, já que C5 encontra-se em concentrações bastante reduzidas no soro de indivíduos brasileiros $(45-190 \mu \mathrm{g} / \mathrm{mL})$. Para solucionar este problema utilizamos uma técnica de alta sensibilidade (ELISA), onde constatamos que o soro da mãe (I:1) e do pai (I:2) apresentam respectivamente 21 e $68 \mu \mathrm{g} / \mathrm{mL}$ de C5 no soro. Os filhos II:4, II:5 e II:9 (pacientes deficientes) apresentam uma concentração bastante reduzida do componente C5 no soro: 1,3; 0,9 e $1,0 \mu \mathrm{g} / \mathrm{mL}$ respectivamente.

O soro dos irmãos saudáveis dos probandos II:3, II:7 e II:8 apresentaram concentrações da proteína C5 $(64,67$ e $54 \mu \mathrm{g} / \mathrm{mL})$ dentro do limite de normalidade para indivíduos brasileros (45-190 $\mu \mathrm{g} / \mathrm{mL})$, sugestivo de um padrão heterozigoto. Os indivíduos da terçera geração dessa família: III:2 (filha do probando II:4) e III:3, III:4, III:5 e III:6 (filhos do probando II:5) apresentam baixa concentração de C5 sérica. Neste caso, estes indivíduos C5D tiveram filhos com parceiros normais (C5 suficientes). A expressão de apenas $\sim 50 \%$ da proteína C5 no soro destes indivíduos é suficiente para establecer a atividade da via clássica e alternativa em patamares próximos ao normal.

Como GARRED et al. (1990) mostraram pela primeira vez que fibroblastos humanos produzem proteínas da via terminal comum do sistema complemento (C5, C6, C7, C8 e C9), usamos estas células como fonte de RNA do gene C5, para estudar as causas moleculares dessa deficiência. Mesmo considerando que os hepatócitos são o local principal de síntese de C5 (COLTEN et al., 1972; GENG et al., 1986), a utilização de fibroblastos como fonte de C5 foi conveniente pela sua acessibilidade, já que seu isolamento (feito a partir de biópsias de pele retiradas dos probandos, familiares e indivíduos normais usados como controle), cultivo 
e manutenção dos repliques dessa célula é relativamente fácil. Nós corroboramos os estudos feitos por GARRED et al. (1990), confirmando a síntese de C5 por estas células.

Até o momento, só três estudos moleculares da deficiência da proteína C5 foram publicados. O primeiro caso descrito por WANG et al. (1995) estudou as causas moleculares da deficiência da proteína C5 em 3 famílias. A primeira família previamente estudada por ROSENFELD et al. (1976) descreveu uma substituição de $C^{4521}$ AG para $T^{4521}$ AG no éxon 36 que criava um códon de parada prematura na cadeia $\alpha$, no lugar da Arg encontrada em indivíduos normais. Na segunda família C5D, previamente estudada por PETER et al. (1981), os autores encontraram uma substituição no éxon 1 de $\mathrm{C}^{84} \mathrm{AG}$ para $\mathrm{T}^{84} \mathrm{AG}$. Esta substituição também cria um códon de parada prematura. Além disso, observou que os todos os indivíduos estudados apresentavam uma condição heterozigota (deleção de 710 pb no éxon 1 na primeira e segunda família e uma deleção do 1010 pb no éxon 36 na terceira família).

Num segundo estudo DELGADO-CERVIÑO et al. (2005) encontraram uma deleção e substituição no éxon 40 de $\mathrm{C}^{4884} \mathrm{C}^{-4885} \mathrm{C}^{-4886}$ por $\mathrm{G}^{4884} \mathrm{C}^{4885}$ em uma família de origem espanhola. Esta mutação também gerou um códon de parada prematura neste mesmo éxon.

PFARR et al. (2005) mostraram que o gene $C 5$ de um menino pakistanês apresentava substituição no éxon 10 de $\mathrm{A}^{1115}$ a $\mathrm{G}^{1115}$ que prediz a substituição de uma $\mathrm{K}^{372}$ por uma $\mathrm{R}^{372}$. Esta alteração (presente só em um dos dois alelos) provoca a diminuição da concentração de C5 no soro dos familiares. Mas no indivíduo deficiente esta alteração encontra-se nos dois alelos o que anula a presença de C5 no soro deste probando. Além disso, após seqüenciamento do cDNA de C5 do probando se confirmou a ausência do éxon 10 (116 pb) que causou uma mudança no quadro de leitura e a criação de um códon de parada prematura. O seqüenciamento também provou que a substituição de $A^{1115}$ por $G^{1115}$ no final do éxon 10 encontra-se dentro de uma região ESE (exonic splicing enhancers) que influenciava a exclusão do éxon 10 no momento da tradução. 
Na Figura 15 observamos a presença de três transcritos de cDNA de C5 em todos os membros da família localizados entre o nucleotídeo 45 ao nucleotídeo 587. CARNEY et al. (1991) demostraram a presença de três transcritos do gene C5 em humanos que se formam dependendo do splicing alternativo. O transcrito completo (Figura 5) de 5818 nucleotídeos que dara origem à proteína $\mathrm{C} 5$ formada pelas duas cadeias $\alpha(115 \mathrm{kDa}) \beta(75 \mathrm{kDa})$. O transcrito truncado pHC5A (Figura 4) que compreende a região que vai do éxon 1 ao éxon 21a (2946 aa). O transcrito pHC5B (Figura 4) que compreende a região que vai do éxon 1 ao éxon 16 (2071 aa).

Numa primeira etapa, comparamos as seqüências do cDNA de C5 de nossos indivíduos deficientes e familiares com as seqüências do cDNA de C5 depositadas no genebank (www.ncbi.nlm.nih.gov) que corresponde à seqüencia de acesso: NM_001735, versão: NM_001735.2 GI:38016946, definição: Homo sapiens complement component 5 (C5), mRNA. No seqüenciamento completo do cDNA C5 da família C5D, encontramos que o pai (I:2) e os filhos (II:4, II:5 e II:9) não expressãm o éxon 30 (Figura 17). A mãe (I:1) apresenta dois produtos, o primeiro que mostra o cDNA C5 completo já mostrado por HAVILAND et al. (1991) e o segundo que mostra o cDNA de C5 que carece do éxon 30 (Figura 17).

A falta do éxon 30 no cDNA dos indivíduos I:1, I:2 e II:9 gerou a seguinte pergunta: a deficiência de C5 seria causada por exclusão do éxon 30 no gene $C 5$ ou por mutações que causariam os defeitos no splicing durante a formação do RNAm de C5?. Quando os éxon 29 31 e respectivos íntrons foram amplificados e seqüenciados partir do gene $C 5$ dos indivíduos

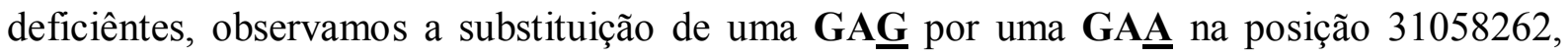
correspondente ao último nucleotídeo do éxon 30 no cDNA. O seqüenciamento da mãe (I:1) apresenta os dois transcritos (padrão heterozigoto) o GAG encontrado no último códon de todos os indivíduos C5 suficientes e o GA $\underline{\mathbf{A}}$ encontrado em todos os indivíduos avaliados 
desta família C5 deficiente, confirmando que os indivíduos desta família C5D têm um problema no splicing do RNAm de C5.

Existem seqüências consenso nos límites éxon - íntron nos pré-RNAm de eucariotes (Figura 21). Os nucleotídeos mais conservados nos introns nucleares são os dois primeiros e os dois últimos nucleotídeos da extremidade 5' e 3' (GU e AG respectivamente). No éxon as regiões mais conservadas são G 3' (55\%) e A e G 5' (67 e 77\% respectivamente). CARNEY et al. (1991) confirmaram esta regra no íntrons do gene C5. No caso dos éxons que forman parte do gene C5 a freqüência de ocorrência é de G na extremidade 3' (44\%) a A e G na extremidade 5' ( 58,5 e 78\%, respectivamente).

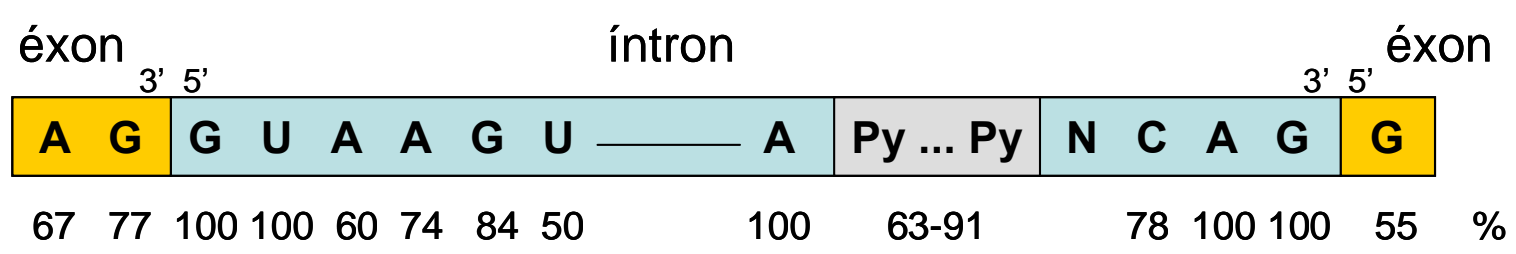

Figura 21. Freqüência de ocorrência (\%) das bases próximas a junção éxon-íntron. As posições mais conservadas (100\%) são as extremidades 5' e 3' do íntron (regra GU-AG). Há uma região de aproximadamente 15 nucleotídeos rica em pirimidinas (Py). A adenina (A) conservada anterior à região rica em Py é o sitio de ramificação da estrutura do laço formada após a excisão do íntron.

O processo químico do splicing consiste em duas transesterificações (Figura 22). A primeira transesterificação ocurre quando o grupo hidroxila da A (punto de ramificação) promove um ataque nucleofílico ao fosfato de ligação fosfodiéster entre o último nucleotídeo do éxon 1 e o intron próximo, rompendo a ligação éxon - íntron e formando um laço (Figura 23 a), o grupo 3' OH livre no éxon 1 (b) ataca o fosfato da ligação fosfodiéster entre o último nucleotídeo do intron a ser excisado e o primeiro nucleotídeo do éxon 2, ligando-se os dois éxons (segunda transesterificação), o íntron removido é degradado. 


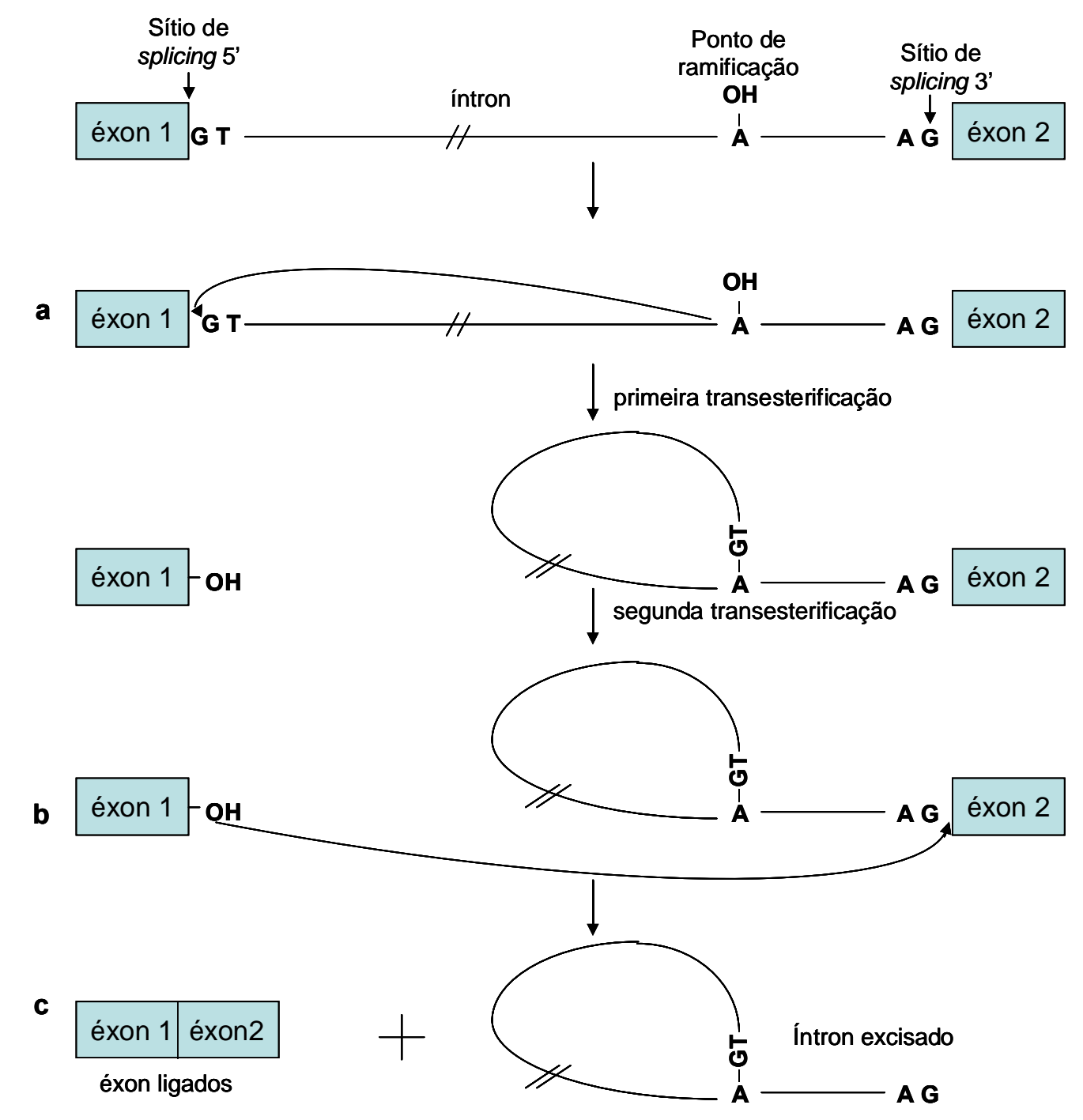

Figura 22. Mecanismo geral de splicing nuclear e de grupo II. O splicing de éxons no préRNAm ocurre através de duas reações de transesterificação (adaptado da tese de doutorado de SAKABE, 2006).

Existem três tipos de introns: os íntron de splicing nuclear, os de grupo I e grupo II. Os introns de grupo I e II são os chamados auto-catalíticos não requerem de nenhuma maquinaria enzimática para a remoção dos intróns "spliceossomo" e os introns de splicing nucleares que requerem do "spliceossomo" para a sua remoção. O spliceossomo é encontrado no nucleo das células eucarióticas, processa os íntrons flanqueados por GT...AG. Este spliceossomo é composto por cinco pequenas ribonucleoproteínas nucleares - snRNPs (U1, U2, U4, U5 e U6) que se ligam a seqüências específicas no íntron. Embora o spliceossomo seja montado durante 
a síntese de RNA, geralmente o íntron não é removido até que a transcrição tenha acabado. $\mathrm{O}$ spliceossomo impide que o éxon 1 afaste-se do éxon 2 após a primeira clivagem. Numa primeira etapa U1 liga-se à região 5' GU. O reconhecimento do sítio 3' (ponte de ramificação + Py + AG) se da pela ligação U2AF e pela ligação U2 no ponto de ramificação. O próximo passo é a ligação de U4/U6 e U5 ao complexo U1/U2, na seguinte etapa U1 desliga-se da região 5' GU, esta região interage com U6, desfazendo o pareamento U4/U6 e formando-se o pareamento U6/U2. O complexo restante (U2/U5/U6) é responsável pelas transesterificações. Pelo tamanho deste complexo um RNAm completamente processado deixa o núcleo. Segundo SAKABE (2006), pg 40, o modelo descrito acima foi baseado em estudos realizados em levadura ou em mini genes artificiales de metazoários contendo apenas um pequeno intron e sítios de splicing fortes [...]. Na maioria de eucariotos os íntrons são maiores que os exons sendo difícil uma comunicação U1/U2 e conseqüente formação do spliceossomo, por isso se propõe-se que o reconhecimento dos sítios do splicing ocorra através do exon.

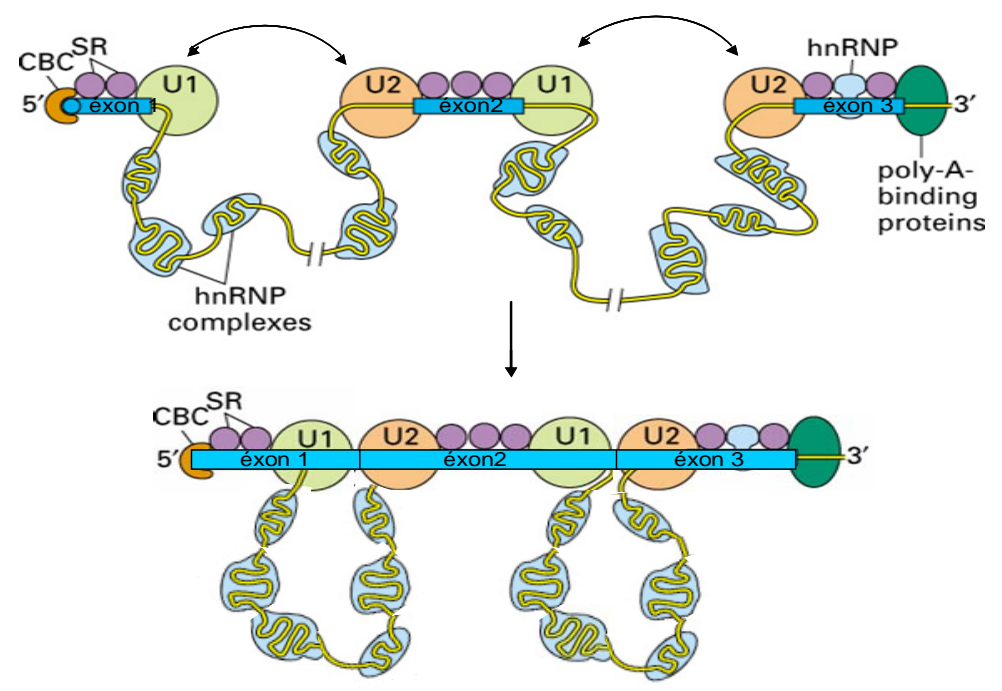

Figura 23. Reconhecimentos dos sítios do splicing através do éxon, proposto por ROBBERSON et al. (1990). As setas curvadas indican interações entre U1 e U2 
No gene C5 os íntrons são maiores que os éxons, o tamanho do íntron varia de 116 a 5600 nucleotídeos (íntron 35 e íntron 25 respectivamente) e o tamanho do éxon varia de 58 a 531 nucleotídeos (éxon 33 e éxon 41 respectivamente). Então o mecanismo de splicing dos íntrons C5 cumpre os requisitos mencionados acima CARNEY et al. (1991).

De acordo com os resultados obtidos na imunodifussão dupla e no Western blot (dados não mostrados) o pae deveria ter um mecanismo de degradação protéica de C5 diferente a do observado nos filhos deficientes (II:4, II:5 e II:9). Sabe-se que toda a família contém a mesma deleção (éxon 30), mas algo deve acontecer com o pai para que ele expresse C5 em níveis séricos baixos, mas claramente superiores aos filhos deficientes.

Até o momento, a literatura reporta só três estudos moleculares da deficiência C5 e nenhuma deles descreveu o tipo de mutação no gene C5 aqui relatado. A substituição deste nucleotídeo no éxon 30 (GAA) a nosso entender é o responsável pela falha no splicing do éxon 30 e conseqüente producção da proteína incompleta nestes pacientes. Nós apresentamos o quarto estudo molecular da deficiência de C5 encontrada pela primeira vez em uma família brasileira com histórico de consangüinidade. Os baixos níveis de C5 nos soros dos deficientes estão associados a maior susceptibilidade a infecções, confirmada pelo elevado número de episódios de meningite, descritos nesta família. Nossos resultados também reafirmam a importância do componente C5 e da completa ativação do sistema complemento para a eliminação de patógenos como Neisseria meningitidis. 
1. Indivíduos deficientes da proteína C5 sofrem de infecções bacteriais causadas por bactérias do gênero Neisseria sp.

2. A falta de atividade hemolítica mediada pela via clássica e pela via alternativa nos indivíduos II:4, II:5 e II:6 deve-se à ausência da proteína C5 no soro dos pacientes deficientes.

3. No éxon 4 do cDNA do indivíduo II:9 a substituição silenciosa de uma $\mathrm{ACC}^{498}$ por uma $\mathrm{ACT}^{498}$ foi encontrada.

4. O cDNA de C5 dos indivíduos I:1, I:2, II:4 e II:9 apresenta a deleção do éxon 30. Causada pela substituição de $\mathrm{GAG}^{4028}$ por $\mathrm{GAA}^{4028}$ no último nucleotídeo deste éxon no gene $C 5$ que leva a um erro no splicing.

5. A mãe (I:2) apresentou um padrão heterozigoto. 
1. AHEARN JM, FISCHER MB, CROIX D, GOERG S, MA M, XIA J, ZHOU X, HOWARD RG, ROTHSTEIN TL, CARROLL MC. Disruption of the Cr2 locus results in a reduction in $B-1$ a cells and in an impaired $B$ cell response to $T$ dependent antigen. Immunity. 4(3):251-62. 1996

2. AitTONIEMI, J., MIETTINEN, A. \& LAIPPALA, P. Age dependent variation in the serum concentration of mannan-binding protein. Acta Pedriatric. 85: 906909. 1996.

3. AITTONIEMI, J., BAER, M., SOPPI, E., VESIKARI, T. \& MIETTINEN, A. Mannan bilding lectin deficiency and concomitant immunodefects. Archieves of Disease in Childhood. 78: 245-248. 1998.

4. AltSchul, S. F., MADDEN, T. L., SCHAFFER, A. A., ZANG, J., ZANG, Z., MILLER, W., LIPMAN, D. J. Gapped BLAST and PSI-BLAST: a new generation of proteín database search programs. Nucleotid Acids Research. 25: 3389- 3402. 1997.

5. AMADEI, N., BARACHO, G.V., NUDELMAN, V., BASTOS, W., FLORIDO, M.P.C. \& ISAAC, L. Inherited complete Factor I deficiency associated with systemic lupus erythematosus, higher suscetibility to infection and low levels of Factor H. Scandinavian Journal of Immunology. 53:615-621. 2001.

6. AMANO, M. T. Deficiência de C1s e C1r Associada ao Desenvolvimento de Lupus Eritematoso Sistemico. 2006. 95 folhas. Dissertação de Tese de Mestrado. Instituto de Ciências Biomédicas- Universidade de São Paulo. 2006.

7. ASGHAR, S., VEBBEKER, G., VAN MEEGEN, M., MEINARDI, M., HULSMANS, R. and WAAL, L. Hereditary deficiency of C5 in association with Discoid Lupus Erithematosus. Journal American Academic Dermathology. 24: 376-378. 1991.

8. AYENSA, C., AGUD, J., GÓMEZ, F. \& ECHEVARRIA, M. Meningococemia recidivante y déficit de C5. Medical clinical - Barcelona. 84(11): 463. 1985.

9. BAJTAI, Z., SPETH, C., ERDEI, A. and DIERICH, M. Cutting Edge: Productive HIV-1 infection of dendritic cells via complement receptor type 3 (CR3, CD11b/CD18). The Journal Immunology. 173: 4775-4778. 2004.

10. BARACHO, G. V. Caracterização Molecular da Deficiência Humana de Fator I, Proteína Regulatória do Sistema Complemento. 2002. 114 folhas. Dissertação de Tese de Mestrado. Instituto de Ciências Biomédicas - Universidade de São Paulo. 2002. 
11. BIESMA, D.H., HANNEMA, A.J., van VELZEN-BLAD, H., MULDER, L., van ZWIETEN, R., KLUIJT, I. \& ROOS, D. A family with complement factor D deiciency. The Journal Clinical Imvestigation. 108(2): 233-240. 2001

12. BLOM, A., VILLOUTREIX, O. \& DAHLBACK, B. Mutation in $\alpha$-chain of C4BP that selectively affect its factor $I$ cofactor function. The American Society for Biochemistry and Molecular Biology. 278(44):43437-43442. 2003.

13. BOLS, A., JANSSENS, J., PEETERMANS, W., STEVENS, E. \& BOBBAERS, H. Recurrent meningococcal infections in a patient with congenital $\mathrm{C} 5$ deficiency. Acta Clinica Belgica. 48: 42-47. 1993.

14. BORK K, BAMSTEDT SE, KOCH P, TRAUPE H. Hereditary angioedema with normal C1-inhibitor activity in women. Lancet. 356: 213-217. 2000.

15. CARNEY, D. F., HAVILAND, D. L., NOACK, D., WETSEL, R. A., VIK, D. P. \& TACK, B. F. Structural aspects of the human C5 gene. Intron-exon organization, 5'- flanking region feature, and characterization of two truncate cDNA clones. The Journal Biological Chemistry. 266(28):18786- 18791. 1991.

16. CESBRON, J. Y., MAILLET, F., VALANCE, J., LANGLET, N. \& KAZATCHKINE, M. Homozygotic C5 deficiency disclosed by purulent Neisseria meningitidis. Presse Medicale. 14: 2287-2289. 1985.

17. Chaudhuri, A. K., BANATVAla, N., CAUGANT, D. A., FAlLON, R. J. \& WHALEY, K. Phenotypically similar clones of serogroup B Neisseria meningitidis causing recurrent meningitis in a patient with total $\mathrm{C5}$ deficiency. The Journal of Infection. 29: 236-238. 1994.

18. COLE F.S., SCHNEEBERGER E.E., LICHTENBERG N.A. \& COLTEN H.R. Complement biosynthesis in human breast-milk macrophages and blood monocytes. Immunology. 46(2):429-441. 1982.

19. COLE F.S., MATTHEWS W.J., ROSSING T.H., GASH D.J., LICHTENBERG N.A. \& PENNINGTON J.E. Complement biosynthesis by human bronchoalveolar macrophages. Clinical Immunology and Immunopathology. 27(2):153-159. 1983.

20. COLTEN. H.R. Ontogeny of the human complement system: in vitro biosynthesis of individual complement components by fetal tissues. The Journal of Clinical Investigation. 51(4):725-730. 1972

21. COOPER, M. A., POMMERING, T. L., KORANYI, K. Primary immunodeficiencies. Am Fam Physician. 68(10):2001-2008. 2003.

22. CORTESIO, C. \& JIANG, W. Mannan-binding lectin-associated serine protease 3 cleaves synthetic peptides and insulin-like growth factor-binding protein 5. Archives of Biochemistry and Biophysics. 449(1-2): 164-170. 2006.

23. DAFFERN, P., PFEIFER, P., EMBER, J. \& HUGLI, T. C3a is a chemotaxin for 
human eosinophils but not for neutrophils I. C3a stimulation of neutrophils is secondary to eosinophils activation. The Journal Experimental Medicine. 181:2119-2127. 1995.

24. DAHL, M. R., THIEL, M., MATSUSHITA, T., FUJITA, A., WILLIS, T., CHRISTENSEN, T., VORUP-JENSEN, T. \& JENSENIUS. MASP-3 and its association with disting complexes of the mannan-binding lectin complement activation pathway. Immunity. 15: 127-135. 2001.

25. DELGADO-CERVIÑO, E., FONTÁN, G. \& LOPEZ-TRASCASA, M. C5 Complement Deficiency in a Spanish Family Molecular Characterization of the Double Mutation Responsible for the Defect. Molecular Immunology. 42: 105111. 2005.

26. DENSEN, P. Interaction of Complement with Neisseria meningitidis and Neisseria gonorrhoeae. Clinical Microbiology Rewies. 2:S11-S17. 1989.

27. DEMPSEY, P., ALliSON, M., AKKARAJU, S., GOODNOW, C. \& FEARON, D. C3d of Complement as a Molecular Adjuvant: Bridging Innate and Acquired Immunity. Science. 271(19):348-350. 1996.

28. DRAGON-DUREY, M. A., QUARTIER, P., FREMEAUX-BACCHI, V., BLOUIN, J., DE BARACE, C., PRIEUR, A. M., WEISS, L., FRIDMAN, W. H. Molecular basis of a selective C1s deficiency associated with early onset multiple autoimmune diseases. The Journal Immunology._166(12):7612-7616. 2001.

29. EHLENBERGER, A. \& NUSSENZWEIG, V. The role of membrane receptors for C3b and C3d in phagocytosis. The Journal Experimental Medicine. 145: 357-370. 1977.

30. EHRENGRUBER, M., GEISER, T., DERANLEAU. Activation of human neutrophils by C3a and C5a. Comparison of the effects on shape changes, chemotaxis, secretion and respiratory burst. FEBS Letters. 346:181-184. 1994.

31. EDEN, A., MILlER, G. \& NUSSENZWEIG. V. Human Lymphocytes Bear Membrane Receptors for C3b and C3d. Journal Clinical Investigation. 52(12): 3239-3242. 1973.

32. ENDO, Y., KANNO, K., TAKAHASHI, M., YAMAGUCHI, K., KOHNO, Y., FUJITA, T. Molecular basis of human complement C1s deficiency. The Journal Immunology.162(4):2180-2183. 1999.

33. ERDEI A, MELCHERS F, SCHULZ T \& DIERICH M. The action of human C3 soluble or cross-linked form wtih resting and activated murine $B$ lymphocytes. European Journal Pediatric Immunology. 15(2):184-8. 1985.

34. FEARON, D. T. Regulation of the amplification C3 convertase of human complement by an inhibitory protein isolated from human erythrocyte membrane. . Proceedings of the National Academy of Sciences of the United States of America. 76(11):5867-5871. 1979 
35. FEDERMANN, G. MAUFF, G., CINQUALBRE, J., JEANBLANC, B., KIENY, R., HAUPTMANN, G, TONGLIO, M.M. \& MAYER, S. Le facteur B de la properdine: polymorphisme, ileu de synthèse et premier cas de déficit génétique. La Nouvelle Presse Medicale. 9(1):45. 1980

36. FERNANDEZ, H., HENSON, P., OTANI, A. \& HUGLI, T. E. Chemotactic response to human $\mathrm{C3a}$ and $\mathrm{C5a}$ anaphylatoxins. I. Evaluation of C3a and C5a leukotaxis in vitro and under simulated in vivo conditions. The Journal Immunology. 120(1):109-115. 1978.

37. FERREIRA DE PAULA, P., BARBOSA, J. E., JUNIOR, P.R., FERRIANI, V., LATORRE, M.R., NUDELMAN, V. \& ISAAC, L. Ontogeny of complement regulatory proteins - concentrations of factor $\mathrm{H}$, factor $\mathrm{I}$, $\mathrm{C} 4 \mathrm{~b}$-binding protein, properdin and vitronecting in healthy children of different ages and adults. Scand J. Immunolo. 58(5):572-577. 2003.

38. FERRIANI, V.P.L., BARBOSA, J.E. \& CARVALHO, I.J. Complete haemolytic (classical and alternative pathways), C3, C4 and factor $B$ titres in healthy children. Acta Pedriatric. 88:1062-1066. 1999

39. FIGUEROA, J. \& DENSEN, P. Infectiuos Diseases associated with complement deficiencies. Clinical Microbiology Rewies. 4(3):359-395. 1991.

40. FIJEN, C. A., KUIJPER, E. J., LINDEBOOM, S. F., VAN OS, J., and VAN PUTTEN, J. P. 2 families with meningococcal infection and hereditary disease of the 5th component of the complement system. Nederlands Tijdschrift Geneeskunde. 133: 1796-1800. 1989.

34. FIJEN, C. A., BREDIUS, G. M., KUIJPER, E. J., OUT, T. A., DE HAAS, M., DE WIT, A. P. M., DAHA, M. R. \& VAN DE WINKEL, J. G. J. The role de Fcy receptor polymorphisms and $\mathrm{C} 3$ in the immune defense against Neisseria meningitides in complement-deficient individuals. Clinical and Experimental Immunology. 120:338-345. 2000

35. FUJIMURA, M. D. Níveis séricos das subclasses da Imunoglobulina G em crianças normais e nefróticas. 1991. Dissertação de Tese de Doutorado em Medicina (Pediatria) Universidade de São Paulo. 1991.

36. FUJITA, T., TAKIUCHI, M., IIDA, K., NAGAKI, K., INAI, S. The activation mechanism of the alternative pathway of the human complement system by the immune precipitate formed with $F\left(a^{\prime}\right) 2$ of rabbit IgG antibody: the generation of C3- and C5-cleaving enzymes on the immune precipitate. Immunochemistry. 14(1):25-30. 1977.

41. FUJTA, T., GIGLI, I. \& NUSSENZWEIG, V. Human C4 binding Protein II. Role in Proteolysis of $\mathbf{C 4 b}$ by $\mathbf{C 3 b}$ inactivator. The Journal Experimental Medicine. 148(4): 1044-1051. 1978. 
42. FUKUMORI, Y. \& HORIUCHI, T. Terminal complement component deficiencies in Japan. Experimental and Clinical Immunogenetics. 15:244-248. 1998.

43. FUKUMORI, Y., YOSHIMURA, K., OHNOKI, S., YAMAGUSHI, H., AKAGAKI, $\mathrm{H}$., INAI, S. A High incidence of C9 deficiency among healthy blood donors in Osaka, Japan. International Immunology. 1:85-89. 1989.

44. GERARD, N. P., BAO, L., XIAO-PING, H., EDDY, R.L., SHOWS, T.B. \& GERARD, C. Human chemiotaxis receptor genes cluster at 19q13.3-13.4. Characterization of the Human C5a receptor gene. Biochesmetry. 32:1243-1250. 1993.

45. GERARD, C. \& GERARD, N. P. C5a anaphylatoxin and its seven transmembrane-segment receptor. Annual Review of Immunology. 12:775-808. 1994.

46. GENG L, IWABUCHI K, SAKAI S, OGASAWARA M, FUJITA M, NOGUCHI M, GOOD RA, MORIKAWA K, ONOE K. A study on location of synthetic site which mainly synthesizes and delivers fifth component of complement system in vivo.Microbiology and Immunology. 30(12):1281-90. 1986.

47. GIANELLA-BORRADORI, A., BORRADORI, L., SCHNEIDER, P., GAUTIER, E. \& SPÄTH, P. Combined complete $\mathrm{C} 5$ and partial $\mathrm{C} 4$ deficiency in Humans: Clinical Consequences and Complement-Mediated Functions in Vitro. Clinical Immunology and Immunopathology. 55:41-55. 1990.

48. GIGLI, I., FUJITA, T. \& NUSSENZWEIG, V. Modulation of the classical pathway $\mathrm{C} 3$ convertase by plasma proteins $\mathrm{C} 4$ binding protein and $\mathrm{C} 3 \mathrm{~b}$ inactivator. (C4b cleavage / C2a decay). Immunology. 76(12): 6596-6600. 1979.

49. GRANT, E.P., PICARELlA, D., BURWELL, T., DELANEY, T., CROCI, A., AVITAHL, N., HUMBLES, A., GUTIERREZ- RAMOS, J., BRISKIN, M. \& GERARD, M. Essencial role for the C5a receptor in regulating the effector phase of synovial infiltration and joint destruction in experimental arthritis. The Journal Experimental Medicine. 196(11): 1461- 1471. 2002.

50. HAAS, K., TOAPANTA, F., OLIVER, J., POE, J., WEIS, J., KARP, D., BOWER, J., ROSS, T. AND TEDDER, T. Cutting Edge: C3d Functions as a Molecular Adjuvant in the Absence of CD21/35 Expression. 2004. The Journal of Immunology. 172: 5833-5837. 2004.

51. HAENEY, M., BALL, A. \& THOMPSON, R. Recurrent Bacterial Meningitis Due To Genetic Deficiencies Of Terminal Complement Components (C5 and C6). Immunobiology. 158:101-106. 1980.

52. HARRISON, R. A., LACHMANN, P. J. Novel cleavage products of the third component of human complement. Molecular Immunology. 17(2):219-228. 1980.

53. HAVILAND DL, MCCOY RL, WHITEHEAD WT, AKAMA H, MOLMENTI EP, BROWN A, HAVILAND JC, PARKS WC, PERLMUTTER DH, WETSEL RA. 
Cellular expression of the $\mathrm{C5a}$ anaphylatoxin receptor (C5aR): demonstration of C5aR on nonmyeloid cells of the liver and lung. The Journal Immunology. 154(4):1861-1969. 1995.

54. HAWLISCH, H., BELKAID, J., BAELDER, R., HILDEMAN, D., GERARD, C. \& KÖHL J. C5a Negatively Regulates Toll-like Receptor 4- Induced Immune Responses. Immunity. 22: 415-426. 2005.

55. HELMY, K.Y., KATSCHKE, K.J.JR, GORGANI, N.N., KLJAVIN, N.M., ELLIOTT, M., DIEHL, L., SCALES, S.S., GHILARDI, N., CAMPAGNE, M.L. CRIg: A Macrophage Complement Receptor Required for Phagocytosis of Circulating Pathogens. Cell. 124(10):915-927. 2006.

56. HIEMSTRA, P., LANGELER, E., COMPIER, B., KEEPERS, Y., LEIJH, P., Van Der BARSELAAR, M., OVERBOSCH, D. \& DAHA, M. Complete and Partial Deficiencies of Complement Factor $D$ in a Dutch family. The Journal Clinical Investigation. 84: 1957-1961. 1989.

57. HILDENHAGEN, O. \& BITTER-SUERMANN, D. Recurrent meningococcal meningitis in hereditary C5 deficiency. Deutsche Medizinische Wochenschrift. 110:1498-1501. 1985.

58. HUBER-LANG, M., YOUNKIN, E., SARMA, J., RIEDEMANN, N., McGUIRE, S., LU, K., KUNKEL, R., YOUNGER, J., ZETOUNE, F. \& WARD, P. Generation of C5a by Phagocytic Cells. American Journal of Pathology. 161(5): 1849-1859. 2002.

59. HUBER-LANG M, SARMA JV, ZETOUNE FS, RITTIRSCH D, NEFF TA, MCGUIRE SR, LAMBRIS JD, WARNER RL, FLIERL MA, HOESEL LM, GEBHARD F, YOUNGER JG, DROUIN SM, WETSEL RA, WARD PA. Generation of $\mathrm{C5a}$ in the absence of $\mathrm{C3}$ : a new complement activation pathway. Nature Medicine. 12(6):682-687. 2006

60. IHARA, I., HARADA, Y., IHARA, Z. \& KAWAKAMI, M. A new complementdepend bactericidal factor found in noimune mouse sera: specific binding to polysaccharide of Ra chemotype salmonella. The American Association of Immunologists. 128(3): 1256-1260. 1982.

61. INAI, S., AKAGAKI, Y. \& MORIYAMA, T. Inter. Archieve Allergy Appl. Immunology. 90:274-279. 1989.

62. IIDA, K., NUSSENZWEIG, V. Functional properties of membrane-associated complement receptor CR1. The Journal Immunology. 130(4):1876-1880. 1983.

63. INOUE, N., SAITO, T., MASUDA, R., SUZUKI, Y., OHTOMI, M., SAKIYAMA, $\mathrm{H}$. Selective complement $\mathrm{C} 1 \mathrm{~s}$ deficiency caused by homozygous four-base deletion in the C1s gene. Human Genetics. 103(4):415-418. 1998.

64. JACOBS, J. C. \& MILLER, M. E. Fatal familial Leiner's disease: a deficiency of the opsonic activity of serum complement. Pediatrics. 49:225-232. 1972. 
65. JENNE, D. \& STANLEY, K. K. Molecular cloning of S-protein, a link between complement, coagulation and cell-substrate adhesion. EMBO J. 4: 3153-3157. 1985.

66. JIAN, H., WAGNER, E., ZHANG, H. \& FRANK, M. M. Complement 1 inhibitor is a regulator of the alternative complement pathway. The Journal of Experimental Medicine. 194: 1609-1616. 2001.

67. KIM, A., Dimitriou, I., HOLlAND, C., MASTEllos, D., MUELler, Y., ALTMAN, J., LAMBRIS, J. \& KATSIKIS, P. Complement C5a Receptor Is Essential for the Optimal Generation of Antiviral CD8+ T Cell Responses. The Journal of Immunology. 173: 2524-2529. 2004.

68. KLAUS G. G. \& HUMPHREY, J. H. The generation of memory cells. I. The role of $\mathbf{C} 3$ in the generation of B memory cells. Immunology. 33(1):31-40. 1977.

69. KLAUS G. G. \& HUMPHREY, J. H. A re-evaluation of the role of C3 in B-cell activation. Immunology Today. 7(6):163-165. 1986.

70. KOHLER, P. \& MÜLLER-EBERHARD, H. Immunochemical quantitation of the third, fourth and fifth components of human complement: concentrations in the serum of healthy adults. The Journal of Immunology. 99(6):1211-1216.1967.

71. LEPOW, I.H., PILLEMER, L \& RATNOFF, O.D. The influence of calcium ions on the inactivation of human complement and its components by plasmin. The Journal of Experimental Medicine. 98(3):277-289. 1953

72. LEPOW, I.H., WURZ, L., RATNOFF, O.D. \& PILlEMER, L. Studies on the mechanism of inactivation of human complement by plasmin and by antigenantibody aggregates. I The requirement for a factor resembling $\mathrm{C} 1$ and the role of Ca++. The Journal Immunology. 73(3):146-158. 1954

73. MANCINI, G., CARBONARA, A. \& HEREMANS, J. Immunochemical quantitation of antigens by single radial immunodiffusion. Immunochesmistry. 2 : 235-254. 1965.

74. MARCUS, R., SHIN, H. \& MAYER, M. An alternate complement pathway: C3 cleaving activity, not due to $\mathrm{C} 4,2 \mathrm{a}$, on endotoxic lipopolysaccharide after treatment with guinea pig serum; relation to properdin. Proceedings of the National Academy of Sciences of the United States of America. 68(6): 1351-1354. 1971.

75. MATSUSHITA, M. \& FUJITA, T. Activation of the classical complement pathway by Mannosa-binding Protein in Association with a novel C1s-like Serine Protease. The Journal of Experimental Medicine. 176:1497-1502. 1992.

76. MATSUSHITA, M., THIEL, S., JENSENIUS, J., TERAI, I. \& FUJITA, T. Proteolytic activities of two types of mannose-binding lectin-associated serine protease. The Journal of Immunology. 165: 2637-2642. 2000. 
77. MAUFF, G., FEDERMANN, G. \& HAUPTMANN, G. A hemolytically inactive gene product of factor B. Immunobiology. 158: 96-100. 1980.

78. McLEOD, B. C., BAKER, P. \& GEWURZ, H. Studies on the inhibition of C56initiated lyses (reactive lyses). II. C567-INH - An inhibitor of the C567 trimolecular complex of complement. International Archieves in Allergy. 47: 623632. 1974.

79. MEDICIUS, R., SCHREIBER, R., GÖTZE, O. \& MÜLLER-EBERHARD. Molecular concept of the properdin pathway. Proceedings of the National Academy of Sciences of the United States of America. 73(2): 612-616. 1976.

80. MEDOF, M. E., LAM, T., PRINCE, G. M., MOLD, C. Requirement for human red blood cells in inactivation of $\mathrm{C} 3 \mathrm{~b}$ in immune complexes and enhancement of binding to spleen cells. The Journal Immunology. 130(3):1336-1340. 1983.

81. MELCHERS F, ERDEI A, SCHULZ T \& DIERICH MP. Growth control of activated, synchronized murine $B$ cells by the $C 3 d$ fragment of human complement. Nature. 317(6034):264-267.1985.

82. MERI, S., MORGAN, B. P, DAVIES, A., DANIELS, R.H., OLAVESEN, M.G., WALDMANN H \& LACHMANN PJ. Human Protein (CD59), am 18,000-20,000 MW complement lysis restricting factor, inhibits C5b-8 catalysed insertion of C9 into lipid bilayers. Immunology. 71(1):1-9. 1990.

83. MILLER, M. E. \& NILSSON, U. R. A familial deficiency of the phagocytosisenhancing activity serum related to a dysfunction of the fifth component of complement (C5). The New England Journal of Medicine. 282:354-358. 1970.

84. MILLER, G. \& NUSSENZWEIG, V. A new complement function: solubilization of antigen-antibody aggregates (Immune-complexes/ immune-complex disease). Proceedings of the National Academy of Sciences of the United States of America. 72(2): 418-422. 1975.

85. MOLLNES, T.E., SONG, W.C. \& LAMBRIS, J. D. Complement in inflammatory tissue damage and disease. Trends in Immunology. 23(2):61-64. 2002.

86. MORGAM, E. L., EMBER, J. A., SANDERSON, S. D., SCHOIZ, W., BUCHNER, R., YE, R. D. \& HUGLI, T. E. Anti-C5a receptor antibodies. Characterization of neutralizing antibodies specific for a peptide, C5aR (9-29), derived from predicted amino-terminal sequence of the human C5a receptor. The Journal of Immunology. 151: 377-388. 1993

87. MORGAN, B. P. \& WALPORT, M. Complement deficiency and disease. Immunology Today. 12(9):301-306. 1991.

88. MORGAN, B. P. Complement: clinical aspects and relevance to disease. Academic Press. 1990. 
89. MORIKIS, D., ASSA-MUNT, N., SAHU, A. \& LAMBRIS, J. D. Solution structure id compstatin, a potent complement inhibitor. Protein Science. 7(3): 619-627. 1998

90. MORLEY, B. \& WALPORT, M. THE COMPLEMENT- Fast Book. Academic Press. 2000.

91. MUELLER-EBERHARD HJ, LEPOW IH. C1 esterase effect on activity and physicochemical properties of the fourth component of complement. The Journal Experimental Medicine. 121:819-833. 1965.

92. NAKED, G.M., FLORIDO, M.C.P., FERREIRA DE PAULA, P., VINET, A.M., INOSTROZA, J.S. \& ISAAC, L. Deficiency of human complement Factor I associated withlowered Factor H. Clinical immunology. 96(2):162-167.2000.

93. NAUTA AJ, CASTELLANO G, XU W, WOLTMAN AM, BORRIAS MC, DAHA MR, VAN KOOTEN C, ROOS A. Opsonization with C1q and mannose-binding lectin targets apoptotic cells to dendritic cells. The Journal Immunology. 173(5):3044-3050. 2004.

94. NICHOLSON-WELLER A, RUSSIAN DA, AUSTEN KF. Natural killer cells are deficient in the surface expression of the complement regulatory protein, decay accelerating factor (DAF). The Journal Immunology. 137(4):1275-1279. 1986

95. NIELSEN, H. E. \& KOCH, C. Meningococcal disease in congenital absence of the fifth component of complement. Scandinavian Journal of Infectious Dissease. 19:635-639. 1987.

96. NILSSON, U., MANDLE, R. \& McCONNELL-MAPES, J. Human C3 and C5: Subunit structure and modifications by trypsin and C42-C423. The Journal of Immunology. 114(2) part 2: 815-822. 1975.

97. NOTORANGElO, L., CASANOVA, J.L., COLLEN, M.E., CHAPEL, H., FISCHER, A., PUCK, J., ROIFMAN, C., SEGER, R., GEHA, R.S. Primary Immunodeficiency Diseases: An update from the International Union of Immunological Societies Primary Immunodeficiency Diseases, Classification Committee meeting in Budapest, 2005. J Allergy Clin Immunol. 117:883-896. 2006.

98. ORREN, A. \& POTTER, P. Complement component C6 deficiency and suceptibility to Neisseria meningitides infections. SAMJ FORUM. 94(5):345-346. 2004.

99. OTONELlO, L., CORCIONE, A., TORTOLINA, G., AIROLDI, I., ALBESIANO, E., FAVRE, A., D’ANGOSTINO, R., MALAVASI, F., PISTOIA, V. \& DALLEGRI, F. rC5a Directs the Vitro Migration of Human Memory and Naïve Tonsillar B Lynfocites: Implications for B Cell Trafficking in Secundary Lymphoid Tissues. The Journal of Immunology. 162:6510-6517. 1999. 
100. OUCHTERNOLY, S. G. \& NILSON, L. Imunodiffusion and immunoelectrophoresis. WEIR, D. M. ed. Handbook of Experimental Immunology, 3era ed. Blackwell, Oxford. Cap. 19, pg: 19.1 - 19.44. 1978.

101. PANGBURN MK, MULLER-EBERHARD HJ. Relation of putative thioester bond in $\mathrm{C} 3$ to activation of the alternative pathway and the binding of $\mathrm{C} 3 \mathrm{~b}$ to biological targets of complement. The Journal of Experimental Medicine. 152(4):1102-1114. 1980.

102. PEPYS, M. B. Role of complement in induction of antibody production in vivo. Effect of cobra factor and other $\mathrm{C} 3$-reactive agents on thymus-dependent and thymus-independent antibody responses. The Journal of Experimental Medicine. 140(1):126- 145. 1974.

103. PETER, G., WEIGERT, M. B., BISSEL, A. R., GOLD, R., KREUTZER, D. \& MC LEAN, R. H. Meningococcal meningitis in familial deficiency of the fifth component of complement. Pediatrics. 67:882-886. 1981.

104. PFARR, N., PRAWITT, D., KIRSCHFINK, M., SCHROFF, C., KNUF, M., HABERMEHL, P., MANNHARDT, W., ZEPP, F., FAIRBROTHER, W., LOOS, M., BURGE, C. \& POHLENZ, J. Linking C5 deficiency to an Exonic, Splicing Enhancer Mutation. The Journal of Immunology. 174: 4172-4177. 2005.

105. PICKERING, M., BOTTO, M., TAYLOR, R. P., LACHMANN, P. J. \& WALPORT, M. J. Systemic lupus eritematosus, complemen deficiency and apoptosis. Advances in Immunology. 76:227-324. 2000.

106. PICKERING, M., COOK, T., WARREN, J., BYGRAVE, A., MOSS, J., WALPORT, M. \& BOTTO, M. Uncontrolled C3 activation causes membranoproliferative glomerulonephritis in mice deficient in complement factor H. Nature Genetics. 31:424-428. 2002.

107. PILLEMER, L., BLUM, L., LEPOW, I., ROSS, O., TODD, E. \& WARDLAW, A. The properdin system and immunity: I. Demonstration and isolation of a new serum protein, properdin, and its role in immune phenomena. Science. 120:279285. 1954.

108. POTTER, P., FRASCH, C., VAN DER SANDERW., COOPER, R., PATEL, Y. \& ORREN, A. Porphylaxis agaist Neisseria meningitides infections and antibody responses in patientes with deficiency of the sixth component complement. The Journal Infectious Diseases. 161:932-937. 1990.

109. PRODEUS, A., GOERG, S., SHEN, L., PODZNYAKOVA, O., CHU L., ALICOT, E., GOODNOW C., CARROLL, M. A critical role for complement in maintenance of self-tolerance. Immunity. 9(5):721-731. 1998.

110. PRUENSTER M, WILFLINGSEDER D, BANKI Z, AMMANN CG, MUELLAUER B, MEYER M, SPETH C, DIERICH MP, STOIBER H. C-type lectin-independent interaction of complement opsonized HIV with monocytederived dendritic cells. European Journal of Immunology. 35(9):2691-2698. 2005. 
111. REED W, ROUBEY RA, DALZELL JG, MATTEUCCI BM, MYONES BL, HUNT SW 3RD, KOLB WP. \& ROSS GD. Synthesis of complement component C5 by human B and T lymphoblastoid cell lines. Immunogenetics. 31(3):145-151. 1990.

112. REIS, E. S., BARACHO, G. V., SOUZA LIMA, A., FARAH, C. \& ISAAC, L. Homozygous hereditary $\mathrm{C} 3$ deficiency due to a premature stop codon. The Journal of Clinical Immunology. 22(6):321-330. 2002.

113. REIS, E. S. Imunodeficiência Primaria do Componente C3 do Sistema Complemento Humano: Identificação das Alterações Moleculares responsáveis por esta Mutação. 2003. 103 folhas. Dissertação de Tese de Mestrado. Instituto de Ciências Biomédicas- Universidade de São Paulo. 2003.

114. REIS, E. S., FALCÃO, D. A. \& ISAAC, L. Clinical aspects and molecular basis of primary deficiencies of complement component $\mathrm{C} 3$ and its regulatory proteins factor I and factor H. Scand J Immunol. 63(3):155-168. 2006a.

115. REIS, E. S., BARBUTO, A. \& ISAAC, L. Complement components, regulators and receptors are produced by human monocyte-derived dendritic cells. Immunobiology. 2006b - em fase de elaboração.

116. RIEDEMANN, N., GUO, R., HOLLMANN, T., GAO, H., NEFF T., REUBEN, J., SPEYER, C., SARMA, V., WETSEL, R., ZETOUNE, F. \& WARD, P. Regulatory Role of C5a in LPS-induced IL-6 production by neutrophils during sepsis. The FASEB Journal. December, 2003.

117. ROSEN, M. S., LORBER, B. \& MYERS, A. R. Chronic meningococcal meningitis. An association with C5 deficiency. Archive of International Medicine. 148:1441-1442. 1988.

118. ROSENFELD, KELLY, M. \& LEDDY, J. Hereditary Deficiency of The Fifth Component of Complement in Man. I. Clinical, Immunochemical and family studies. The Journal of Clinical Investigation. 57:1626-1634. 1976.

119. ROSENFELD, S., BAUM, J., STEIGBIGEL, R. \& LEDDY, J. Hereditary Deficiency of the Fifth Component of Complement in Man. II. Biological Properties of C5 Deficient Human Serum. The Journal of Clinical Investigation. 57:1635-1643. 1976.

120. ROTHMAN BL, MERROW M, BAMBA M, KENNEDY T, KREUTZER DL. Biosynthesis of the third and fifth complement components by isolated human lung cells. The American Review of Respiratory Disease. 139(1):212-220. 1989.

121. SANAL, Ö., LOOS, M., ERSOY, F., KANRA, G., SEÇMEER, G. \& TEZCAN, I. Complement component deficiencies and infection: $\mathrm{C5}, \mathrm{C} 8$ and $\mathrm{C3}$ deficiencies in three families. European Journal Pediatric. 151:676-679. 1992.

122. SCHOONBROOD, T., HANNEMA, A., FIJEM, C., MARKUSSE, H. \& SWAAK, A. C5 Deficiency in a Patient with Primary Sjögren's Syndrome. Caso ReportJournal Rheumatology. 22:1389-1390. 1995. 
123. SHIN, H. S., PICKERING, R. J. \& MAYER, M. M. The fifth component of guinea pig complement system. III. Dissociation and transfer of $\mathbf{C 5 b}$, and the Probable site of C5b fixation. The Journal of Immunology. 106(2):480-493. 1971.

124. SHINKAY, Y., TAKIO, K., OKUMURA, K. Homology of perforin to the ninth component of complement (C9). Nature. 334(6182):525-527.1988.

125. SIM, R. B., REBOUL, A. \& ARLAUD, G. J. Interaction of $\mathbf{I}^{\mathbf{1 2 5}}$ labeled complement components $\mathrm{C} 1-\mathrm{r}$ and $\mathrm{C} 1-\mathrm{s}$ with protease inhibitors in plasma. FEBS Lett. 97:11-115. 1979.

126. SNYDERMAN, R., PIKE, M., McCARLEY, D. \& LANG, L. Quantification of mouse macrophage chemotaxis in vitro: Role C5 for the production of chemotactic activity. Infection and Immunity. 11(3):488-492. 1975.

127. SNYDERMAN, R., DURACK, D., McCARTHY, G., WARD, F. \& MEADOWS, L. Deficiency of the Fifth Complement in Human Subjects. Clinical, Genetic and Immunologic Studies in a Large Kindred. The American Journal of Medicine. 67:638-645. 1979.

128. SPRONG, T., BRANDTZAEG, P., FUNG, M., PHARO, A., HǿIBY, A., MICHAELSEN, T., AASE, A., VAN DER MEER, J., VAN DEUREN, M. \& MOLLNES, T. Inhibition of C5a-induced inflammation with preserved C5b-9mediated bactericidal activity in a Human Whole Blood Model of Meningococcal Sepsis. Immunobiology-Blood. 102(10):3702-3710. 2003

129. STREY, C., MARKIEWSKI, M., MASTELLOS, D., TUDORAM, R., SPRUCE, L., GREENBAUM, L. \& LAMBRIS, J. The proinflammatory mediators C3a and C5a are essential for liver regeneration. The Journal of Experimental Medicine. 6:913-923. 2003

130. STRUNK RC, EIDLEN DM, MASON RJ. Pulmonary alveolar type II epithelial cells synthesize and secrete proteins of the classical and alternative complement pathways. The Journal of Clinical Investigation. 81(5):1419-1426. 1988.

131. SUMMERFIELD, J., SUMIYA, M., LEVIN, M. \& TURNER, M. Association of mutations in mannose binding protein gene with chilhood infection in consecutive hospital series. The British Medical Journal. 314:1229. 1997.

132. SUMIYA, M., TABONA, P., ARAI, T., SUMMERFIELD, J. A., SUPER, M., LEVINSKY, R. \& TURNER, M. W. Molecular basis of opsonic defect in immunodeficiente children. 2003

133. SUPER, M., LU, J., THILED, S., LEVINSKY, R. \& TURNER, M. W. Association of low levels of mannan-binding protein with a common defect of opsonisation. Lancet. 2(8674):1236-1239. 1989

134. TACK, B., MORRIS, S. \& PRAHL, J. Fifth Component of Human Complement: purification from plasma and polypeptide chain structure. Biochesmistry. 1490- 
1497. 1979.

135. TAKAHASHI, M., ENDO, Y., FUJITA, T. \& MATSUSHITA, M. A truncated form of mannose-binding lectin-associated serine protease (MASP)-2 expressed by alternative polyadenylation is a component of the lectin complement pathway. International Imunology. 11:859-864. 1999.

136. TAUBMANN, S. B. GOLSCHMIDT, P. R. and LEPOW, I. J. Effects of lysosomal enzymes from human leukocyte on human complement component. Fed. Proc. 29:434. 1970.

137. TAYLOR, P., CARUGATI, A., FADOK, V., COOK, H., ANDREWS, CARROLL, M., SAVILL, J., HENSON, P., BOTTO, M. \& WALPORT, M. A Hierarchical Role for Classical Pathway Complement Proteins in Clearance of Apoptotic Cell in Vivo. The Journal of Experimental Medicine. 192(3):359-366. 2004.

138. THIEL, S., VORUP-JENSEN, T., STOVER, C., CHWAEBLE, W., LAURSEN, S., POULSEN, K., WILlIS, A., EGGLETON, P., HANSEN, S., HOLMSKOV, U., REID, K. \& JENSENIUS, J. A second serine protease associated with mannanbinding lectin that activates complement. Nature. 386:506-510. 1997.

139. TSCHOPP, J., MASSON, D., SCHÄFER, S., PEITSCH, M. \& PREISSNER, K. T. The heparin binding domain of S-protein/vitronectin bind to complement components $\mathrm{C}$, C8 and $\mathrm{C} 9$ and perforin from cytolytic T-cells and inhibits their lytic activities. Biochemistry. 27:4103-4109. 1988.

140. ULBRICH, A. G., FLORIDO, M. C. P., NUDELMAN, V., REIS, E. S., BARACHO, G. V. \& ISAAC, L. Hereditary human complement $\mathbf{C 3}$ deficiency owing to reduced levels of C3 mRNA. The Scandinavian Journal of Immunology. 53:622626. 2001.

141. VYSE, T. J., SPÄTH, P. J., DAVIES, K. A. MORLEY, B. J., PHILIPPE, P., ATHANASSIOU, P., GILES, C. M. \& WALPORT, M. J. Hereditary Complement Fator I Deficiency. An International Journal of Medicine. 87:385-401. 1994.

142. WANG, X., FLEISCHER, D., WHITEHEAD, W., HAVILAND, D., ROSENFELD, S., LEDDY, J., SNYDERMAN, R. \& WETSEL, R. Inherited Human Complement C5 Deficiency. The Journal Immunology. 154:5464-5471. 1995.

143. WARD, P. A. \& NEWMAN, L. J. A neutrophil chemotactic factor from human C5. The Journal of Immunology. 102:93-99. 1969.

144. WARE, C. \& KOLB, W. Assembly of the Funtional Membrane Attack complex of Human Complement: Formation of Disulfide-linked C9 Dimers. Proceedings of the National Academy of Sciences of the United States of America. 78(10):64266430. 1981.

145. WEN, L., ATKINSON, J. \& GICLAS, P. Clinical and Laboratory Evaluation of Complement Deficiency. Current Reviews of Allergy and Clinical Immunology. 113(4): 585-593. 2004. 
146. WETSEL, R., LEMONS, R., LE BEAU, M., BARNUM, S., NOACK, D. \& TACK, B. Molecular Analysis of Human Complement Component C5: Localization of the Structural Gene to Chromosome 9. Biochemistry. 27:1474-1482. 1988.

147. WHALEY K. Biosynthesis of the complement components and regulatory proteins of the alternative complement pathway by human peripheral blood monocytes. The Journal of Experimental Medicine. 151(3):501-516. 1980.

148. WILlOUGHBY, W.F. \& MAYER, M.M. Antibody-complement complexes. Science. 150(698):907-908. 1965.

149. WINTROBE, 1era edition. 1988.

150. WYMANN, M., TSCHARNER, V., DERANLEAU, D. \& BAGGIOLINI, M. The onset of the respiratory burst in human neutrophils. The Journal of Biological Chemistry. 262(25):12048-12053. 1987.

151. YAZDANBAKHSH, K., KANG, S., TAMASAUSKAS, D., SUNG, D. \& SCARADAVOU, A. Complement receptor 1. inhibitors for prevention of imunemediated red cell destruction: potential use in transfusion therapy. Transfusion Medicine - Blood. 101(12):5046-5052. 2003

152. ZOPPI, M., WEISS, M., NYDEGGER, U., HESS, T. \& SPÄTH, P. Recurret Meningitis in a Patient with Congenital Deficiency of the C9 Component of Complement. Firts case of C9 Deficiency in Europe. Archieves of Internal Medicine. 150:2395-2399. 1990.

153. ZUNDEL, S., CSEH, S., LACROIX, M., DAHL, M., MATSUSHITA, M., ANDRIEU, J., SCHWAEBLE, W., JENSENIUS, J., FUJITA, T., ARLAUD, G. \& THIELENS, N. Characterization of recombinant mannan-binding lectinassociated serine protease (MASP-3) suggests an activation mechanism different from that of MASP-1 and MASP-2. The Journal of Immunology. 172:4342-4350. 2004. 